\title{
Metagenomic insights into the reservoirs and dissemination of antibiotic resistance
}

Citation for published version (APA):

von Wintersdorff, C. J. H. (2016). Metagenomic insights into the reservoirs and dissemination of antibiotic resistance. [Doctoral Thesis, Maastricht University]. Proefschriftmaken.nl || Uitgeverij BOXPress. https://doi.org/10.26481/dis.20161219cw

Document status and date:

Published: 01/01/2016

DOI:

$10.26481 /$ dis.20161219cw

Document Version:

Publisher's PDF, also known as Version of record

\section{Please check the document version of this publication:}

- A submitted manuscript is the version of the article upon submission and before peer-review. There can be important differences between the submitted version and the official published version of record.

People interested in the research are advised to contact the author for the final version of the publication, or visit the DOI to the publisher's website.

- The final author version and the galley proof are versions of the publication after peer review.

- The final published version features the final layout of the paper including the volume, issue and page numbers.

Link to publication

\footnotetext{
General rights rights.

- You may freely distribute the URL identifying the publication in the public portal. please follow below link for the End User Agreement:

www.umlib.nl/taverne-license

Take down policy

If you believe that this document breaches copyright please contact us at:

repository@maastrichtuniversity.nl

providing details and we will investigate your claim.
}

Copyright and moral rights for the publications made accessible in the public portal are retained by the authors and/or other copyright owners and it is a condition of accessing publications that users recognise and abide by the legal requirements associated with these

- Users may download and print one copy of any publication from the public portal for the purpose of private study or research.

- You may not further distribute the material or use it for any profit-making activity or commercial gain

If the publication is distributed under the terms of Article $25 \mathrm{fa}$ of the Dutch Copyright Act, indicated by the "Taverne" license above, 


\section{Metagenomic insights into the reservoirs and dissemination of antibiotic resistance}

Christian Johannes Hendrik von Wintersdorff 
ISBN: 978-94-6295-539-4

Cover design: Mayk Lucchesi

Printed and published by: Proefschriftmaken.nl - Uitgeverij BOXPress

(C) Christian von Wintersdorff, Brunssum 2016

All rights reserved. No part of this thesis may be reproduced, stored in a retrieval system or transmitted in any form or by any means, electronic or mechanical, including photocopy, without prior written permission of the publisher and copyright owner, or where appropriate, the publisher of the articles.

Printing of this thesis was financially supported by the Netherlands Society of Medical Microbiology (NVMM) and the Royal Netherlands Society for Microbiology (KNVM) 


\section{Metagenomic insights into the reservoirs and dissemination of antibiotic resistance}

\section{PROEFSCHRIFT}

ter verkrijging van de graad van doctor aan de Universiteit Maastricht, op gezag van de Rector Magnificus, Prof. dr. Rianne M. Letschert volgens het besluit van het College van Decanen, in het openbaar te verdedigen

op maandag 19 december 2016 om 12.00 uur

door

Christian Johannes Hendrik von Wintersdorff 


\section{Promotor}

Prof. dr. P.H.M. Savelkoul

\section{Copromotores}

Dr. ir. P.F.G. Wolffs

Dr. J. Penders

\section{Beoordelingscommissie}

Prof. dr. A.A.M. Masclee (voorzitter)

Prof. dr. K. Horstman

Prof. dr. J.A.J.W. Kluytmans (VUmc, Amsterdam)

Dr. ir. W.H. van Schaik (UMC, Utrecht)

Prof. dr. K. Venema 
"The moral of the story. . . one should not try to second-guess microbes! If resistance is biochemically possible, it will occur."

Julian Davies, 2010 



\section{Contents}

Chapter 1 General introduction \& outline of the thesis

Chapter 2 Dissemination of antimicrobial resistance in microbial ecosystems through horizontal gene transfer Front Microbiol. 2016 Feb 19;7:173

Chapter 3 The gut resistome is highly dynamic during the first 41 months of life

Future Microbiol. 2016 Apr;11:501-10

Chapter 4A High rates of antimicrobial drug resistance gene acquisition after international travel, the Netherlands Emerg Infect Dis. 2014;20(4):649-57.

Chapter 4B Longitudinal fluctuations of common antimicrobial resistance genes in the gut microbiomes of healthy Dutch individuals Manuscript in preparation

Chapter 5 Acquisition of travel-associated antibiotic resistant bacteria occurs within several days Manuscript in preparation

Chapter 6 Detection of the plasmid-mediated colistin-resistance gene $\mathrm{mcr}-1$ in faecal metagenomes of Dutch travellers Essentially described in J. Antimicrob. Chemother. 2016 (in press)

Chapter 7 General discussion and summary

Samenvatting

Valorisation

Dankwoord

Curriculum vitae

List of publications 



\section{Chapter 1}

General introduction \& outline of the thesis 


\section{Antibiotics, resistance and the resistome}

Since their discovery in 1928 by Alexander Fleming and their introduction for the treatment of infections in humans in 1941, antibiotics have truly revolutionized the field of infectious diseases. Since then, both minor and life threatening infections can be cured by these compounds, which either inhibit the growth of, or kill bacteria. Moreover, antibiotics are critical to the success of advanced surgical procedures, such as organ and prosthetic transplants, making them an invaluable asset to mankind.

Within 70 years after introduction of antibiotics, the emergence of antimicrobial resistance has become a major threat to the effectiveness of these antimicrobial agents. Bacterial resistance to antibiotics is a naturally occurring phenomenon [1, 2], which has existed far longer than humans have [3]. The human use of antibiotics has, however, greatly increased the occurrence and spread of antimicrobial resistance among bacteria and resistance is increasingly encountered in the clinic [4]. Consequently, infections with such resistant bacteria require treatment with newer, often more broad spectrum, antibiotics. With a lack of novel antibiotics in the pipeline, we are now rapidly reaching the point where an increasing number of infections are extremely difficult to treat or may even become completely untreatable due to multidrug or pandrug resistance [5, 6]. For this reason, a thorough understanding of the spread of antibiotic resistance is crucial to be able to limit its further dissemination and preserve existing antibiotics.

Besides antibiotic resistance encountered in clinical pathogens, the collection of all antibiotic resistance genes (ARGs) in microbial ecosystems, known as the resistome, is also relevant. All microbes in such an ecosystem, including pathogenic, commensal and environmental bacteria, form a reservoir [7] from which antibiotic resistance can be acquired via a process called horizontal gene transfer (HGT) [8]. For this reason, antibiotic selection pressure on all microbes encountered in e.g. the human gut, but also those in animals, or even the environment may affect the emergence of resistance in other (potentially pathogenic) bacteria. This creates a complex interplay between antibiotic use and resistance throughout the global microbial community. 


\section{Studying the resistome: metagenomic techniques}

When studying the resistome of a microbial community, traditional culturing techniques would come with large drawbacks, as many bacterial species are not cultivable [9]. Molecular techniques in which total DNA (the metagenome) is extracted directly from a sample, provide a more complete representation of (antibiotic resistance) genes present in such a community. The resistome can be studied using various molecular techniques, including sequence-based, functional or targeted metagenomics. Each of these techniques have their own strengths and weaknesses (Figure 1), making each of them valuable for different purposes.

With sequence-based techniques, the sequence of every kind of DNA (human, microbial etc.) present in a sample can be determined, which provides a wealth of information. This information can be used to study not only the taxonomic composition but also the functional capacity of a microbial community, including the resistome. However, analysis of such data is largely dependent on prior knowledge, since it relies on comparisons with annotated genes which have been deposited in existing reference databases [10].

Through functional metagenomics, DNA fragments from any metagenome are inserted into a vector (e.g., a plasmid), after which its functionality is investigated by expression in a heterologous host. Subsequently, the resulting transformants can be screened for the expression of resistance genes by growing them on antibiotic containing media. Such an approach is very useful for identifying previously uncharacterized genes and is thus independent of prior knowledge. Moreover, this technique can confirm whether a gene is functional, which adds to its reliability. This may also be a downside however, as functional DNA which cannot be expressed by the heterologous host is not detected. Also, this technique is quite labour intensive, making it less suitable for larger study populations [10, 11].

Throughout this thesis, targeted metagenomics has been the method of choice. In this approach, specific targets (in this case ARGs) can be amplified and detected [10]. As with sequence-based metagenomics, prior knowledge is required to be able to select for targets. The major strength of this technique is that it has a very high sensitivity compared to the previous two methods. Additionally, this method is less laborious, allowing for a high throughput and thus enabling its application in large epidemiological studies. 


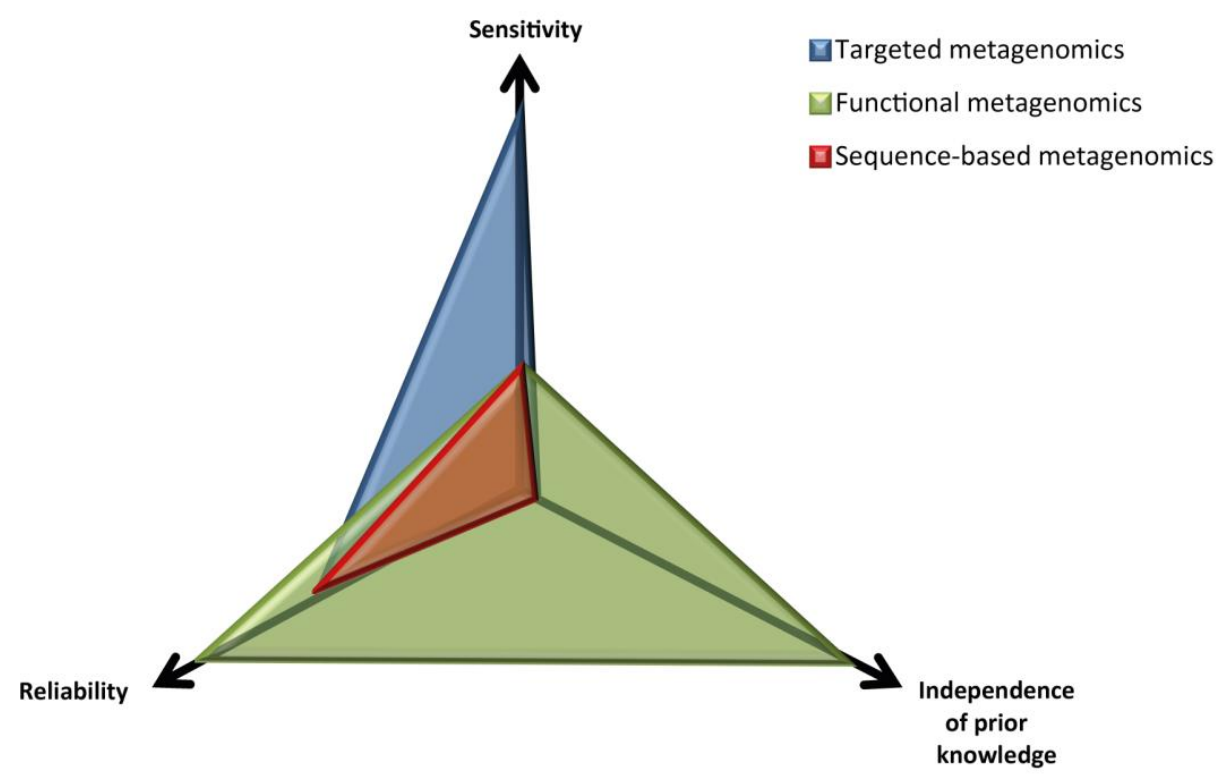

Figure 1. Comparison of characteristics of three metagenomic techniques. Adapted from Sommer et al. [12] with permission. The different metagenomic techniques score variably with regards to: sensitivity (top corner), the degree which less abundant DNA sequences in a metagenome are included; independence of prior knowledge (right corner), how much it relies on previously determined DNA sequences; and reliability (left corner), how well its findings may be interpreted as functional resistance. 


\section{Aim and outline of the thesis}

Because of the interplay within microbial ecosystems, where resistance in one bacterium may disseminate to others, all resistance elements present in those ecosystems are potentially relevant to human health. Therefore, studying the resistome in addition to resistance in clinical isolates may provide a more comprehensive understanding of the dissemination of antibiotic resistance. Because of its high density of microorganisms, the gut microbiota is perhaps one of the most accessible reservoirs of antibiotic resistance (9). The gastrointestinal tract is constantly exposed to numerous bacteria from the environment, e.g., food, water, soil, other humans, or animals. These incoming bacteria often harbour antimicrobial drug resistance genes (10), which can be transferred to the indigenous microbial communities (including opportunistic pathogens) through HGT $[10,13,14]$. The aim of this thesis was to contribute to our understanding of the microbial resistome in relation to the human gut microbiota.

In chapter 2, the literature on the dissemination of antimicrobial resistance in microbial ecosystems is reviewed by discussing the concept of the resistome in detail, providing examples of HGT of clinically relevant ARGs and describing the contributions of the various HGT mechanisms to the spread of antibiotic resistance.

While it is known that antibiotic resistant bacteria are present in the environment as well as in and on our body, there is very limited data on when and how such bacteria colonize our body. Are we born with resistant bacteria, or does gradual exposure in life slowly lead to their acquisition? In chapter 3, we explored the early development of the human gut resistome and potential deterministic factors, by investigating the longitudinal development of several antibiotic resistance genes (ARGs) of the infant gut resistome during the first months after birth.

The dissemination of antibiotic resistance is affected and accelerated by various human activities. In an era of increasing globalization, the acquisition and dissemination of antibiotic resistant bacteria through international travel is a major concern. While exposure to antibiotic resistant bacteria during a travel is a risk for developing infections with such resistant bacteria, the trafficking of resistome elements could also lead to their introduction and further dissemination in other environments. In chapter $\mathbf{4 A}$, we studied how the gut 
resistome of travellers is affected by international travel. Next, in chapter 4B, we investigated whether several of the observations made concerning ARGs in the gut microbiome could be attributed to travel, or if they were also observable in a non-travelling study group.

Continuing on international travel and acquisition of antibiotic resistance genes, there is currently no data available on the actual dynamics of the resistome during travel itself. It is for example not known how fast ARGs are acquired. In chapter 5 we therefore investigated the dynamics of the travellers' resistome by monitoring several ARGs in the microbiomes of travellers during the course of their travels.

The prevalence of extended spectrum beta-lactamase (ESBL) producing bacteria has increased greatly over the last decade. Such bacteria are unsusceptible to commonly used beta-lactamases, and are often resistant to many other antibiotics as well, leaving limited treatment options, such as the carbapenem antibiotics available. However, resistance to carbapenems is also increasing at an alarming rate, and has even become endemic in some regions in recent years. Consequently, infections with carbapenem resistant bacteria are often treatable only with last resort antibiotics such colistin. In November 2015 however, the first plasmid mediated colistin resistance gene $(\mathrm{mcr}-1)$ was identified, heralding a major breach in our last line of defence. In chapter 6, we therefore investigated the presence of the $\mathrm{mcr}^{-1}$ gene in the gut resistome of Dutch international travellers, assessing its prevalence and risk of dissemination.

Finally, in chapter 7, the results and findings of our studies are summarized and discussed. Furthermore we evaluate on the current standings of the antibiotic resistance problem, how investigating the resistome has contributed to our understanding of it, and discuss future perspectives. 


\section{References}

1. Aminov RI. The role of antibiotics and antibiotic resistance in nature. Environ Microbiol. 2009;11(12):2970-88.

2. Martinez JL. Antibiotics and antibiotic resistance genes in natural environments. Science. 2008;321(5887):365-7.

3. D'Costa VM, King CE, Kalan L, Morar M, Sung WW, Schwarz C, et al. Antibiotic resistance is ancient. Nature. 2011;477(7365):457-61.

4. Davies J, Davies D. Origins and evolution of antibiotic resistance. Microbiol Mol Biol Rev. 2010;74(3):417-33.

5. Nordmann P. Carbapenemase-producing Enterobacteriaceae: overview of a major public health challenge. Med Mal Infect. 2014;44(2):51-6.

6. Paterson DL, Harris PN. Colistin resistance: a major breach in our last line of defence. Lancet Infect Dis. 2016;16(2):132-3.

7. Wright GD. The antibiotic resistome. Expert Opin Drug Discov. 2010;5(8):779-88.

8. von Wintersdorff CJ, Penders J, van Niekerk JM, Mills ND, Majumder S, van Alphen LB, et al. Dissemination of Antimicrobial Resistance in Microbial Ecosystems through Horizontal Gene Transfer. Front Microbiol. 2016;7:173.

9. Eckburg PB, Bik EM, Bernstein CN, Purdom E, Dethlefsen L, Sargent M, et al. Diversity of the human intestinal microbial flora. Science. 2005;308(5728):1635-8.

10. Penders J, Stobberingh EE, Savelkoul PH, Wolffs PF. The human microbiome as a reservoir of antimicrobial resistance. Front Microbiol. 2013;4:87.

11. Pehrsson EC, Forsberg KJ, Gibson MK, Ahmadi S, Dantas G. Novel resistance functions uncovered using functional metagenomic investigations of resistance reservoirs. Front Microbiol. 2013;4:145.

12. Sommer MO. Delineating the dissemination of antibiotic resistance genes within microbial communities. 6th Congress of European Microbiologists; 7-11 June 2015; Maastricht, The Netherlands.

13. Baquero F. Metagenomic epidemiology: a public health need for the control of antimicrobial resistance. Clin Microbiol Infect. 2012;18 Suppl 4:67-73.

14. van Schaik W. The human gut resistome. Philos Trans R Soc Lond B Biol Sci. 2015;370(1670):20140087. 


\section{Chapter 2}

Dissemination of antimicrobial resistance in microbial
ecosystems through horizontal gene transfer

Christian J.H. von Wintersdorff, John Penders, Julius M. van Niekerk, Nathan D. Mills, Snehali Majumder, Lieke B. van Alphen, Paul H.M. Savelkoul \& Petra F.G. Wolffs

Front Microbiol. 2016 Feb 19;7:173 


\section{Abstract}

The emergence and spread of antibiotic resistance among pathogenic bacteria has been a rising problem for public health in recent decades. It is becoming increasingly recognized that not only antibiotic resistance genes (ARGs) encountered in clinical pathogens are of relevance, but rather, all pathogenic, commensal as well as environmental bacteria - and also mobile genetic elements and bacteriophages - form a reservoir of ARGs (the resistome) from which pathogenic bacteria can acquire resistance via horizontal gene transfer (HGT). HGT has caused antibiotic resistance to spread from commensal and environmental species to pathogenic ones, as has been shown for some clinically important ARGs. Of the three canonical mechanisms of HGT, conjugation is thought to have the greatest influence on the dissemination of ARGs. While transformation and transduction are deemed less important, recent discoveries suggest their role may be larger than previously thought. Understanding the extent of the resistome and how its mobilization to pathogenic bacteria takes place is essential for efforts to control the dissemination of these genes. Here, we will discuss the concept of the resistome, provide examples of HGT of clinically relevant ARGs and present an overview of the current knowledge of the contributions the various HGT mechanisms make to the spread of antibiotic resistance. 


\section{Introduction}

The ever-increasing magnitude of antimicrobial resistance (AMR) encountered in human pathogens is a huge concern for public health worldwide, limiting treatment options for bacterial infections and thereby reducing clinical efficacy while increasing treatment costs and mortality. With a lack of development of new antibiotics, and increasing resistance even to last-resort antibiotics [1], there is a need to conserve the ones available.

Natural antibiotics have existed for billions of years [2-5], providing a selective benefit for the producing strains by inhibiting or eliminating other bacteria competing for resources [6, 7]. Additionally, their function as cell-cell signalling molecules has been described [8, 9]. Just as antibiotics are ancient, so are antibiotic resistance genes (ARGs), as evidenced by studies identifying various ARGs in ancient permafrost samples [10,11] and isolated cave microbiomes [3]. Resistance to antibiotics can occur either by mutations or by acquisition of resistance conferring genes via horizontal gene transfer (HGT), of which the latter is considered to be the most important factor in the current pandemic of antimicrobial resistance.

The HGT of ARGs also far predates the production and use of antibiotics by humans. For example, OXA-type $\beta$-lactamases were found to be plasmid-borne and able to transfer between bacterial species millions of years ago [2]. However, while antibiotic resistance and its spread by HGT are ancient mechanisms, the rate at which these processes occur and the number of resistant strains has increased tremendously over the past few decades because of selective pressure through human antibiotic use.

\section{The global antibiotic selection pressure}

While the discovery of antibiotics revolutionized the field of medicine, their increasingly large-scale production and consumption has had widespread effects on the microbial biosphere. In their analysis, Van Boeckel et al. showed that global human antibiotic consumption amounted to 54,083,964,813 standard units (pills, capsules, or ampoules) in 2000 and had increased by $36 \%$ to $73,620,748,816$ standard units by 2010 [12]. The same authors estimated that antibiotic consumption in food animals, which is assumed to be larger than that of humans, was over 63 million $\mathrm{kg}$ in 2010 and will also drastically increase in the coming 
years [13] despite recent initiatives to reduce antibiotic use in animals. Such high and continuously increasing amounts of antibiotics overwhelm the natural production, causing a constantly increasing selection pressure on bacterial populations in all exposed environments.

The use and misuse of antibiotics in medicine, agriculture, and aquaculture has been linked to the emergence of resistant bacteria in these settings [14-16]. However, the impact of antibiotic usage extends further, as antibiotic residues, resistant bacteria, and genetic resistance elements subsequently spread to adjacent environments. The majority of consumed antibiotics are excreted unchanged [17] and are then introduced into the environment directly or through waste streams. Such waste streams, as well as wastewater treatment plants, are considered to be hotspots for the dissemination of AMR, since resistance genes, mobile genetic elements (MGEs), and (sub-inhibitory) antibiotic selection pressure from various sources are introduced to commensals and pathogens [18-21]. Moreover, the antibiotic compounds are often not completely removed in treatment plants $[22,23]$, from where they then disseminate further. A study by Larsson et al. showed that a treatment plant in India, receiving water from drug manufacturing sites, exposes its direct environment to very high levels of antibiotics, discharging approximately $45 \mathrm{~kg}$ of ciprofloxacin per day [24], contaminating surface, ground, and drinking water in the area [25]. Consequently, not only were highly multiresistant bacteria found to be common within the treatment plant [26], but high levels of ARGs and MGEs were also detected in nearby river sediments [27].

How environmental exposure to antibiotics contributes to the selection of resistant strains and the increase of resistome elements is illustrated by a study comparing soil samples taken between 1940 and 2008, which shows that ARGs from all classes of antibiotics tested (beta-lactams, tetracyclines, erythromycins, and glycopeptides) significantly increased since 1940, with a tetracycline ARG being over 15 times more abundant than in the 1970s [28]. Moreover, the increasing selection pressure has altered bacterial HGT processes, increasing the number of resistome elements which reside on mobile DNA compared to the preantibiotic era [29]. 


\section{Reservoirs of resistance}

In order to understand the dissemination of antibiotic resistance, it is necessary to map the resistomes of various environments, and to unravel the extent to which these environments act as reservoirs for the dissemination of ARGs to bacterial pathogens. In recent years there has been increasing interest in this matter, as many studies have used various techniques to sample the resistome of environments such as, but not limited to, soil, wastewater, and human and animal gut microbiota. [30-33]. It has become clear that ARGs, including clinically relevant ones, are widespread in such environments [34]. Studies applying a metagenomic approach directly recover DNA from all microorganisms in a biological sample, thereby avoiding the bias that is introduced when selecting certain organisms and allowing for the investigation of the resistome of microbial ecosystems. The sequencing of metagenomes from various environments has provided a wealth of data which is often publicly available in databases. Such databases can be mined for the presence of resistance genes, even when the initial studies did not focus specifically on ARG content in these metagenomes. For example, mining such metagenomic databases for the plasmid-mediated colistin resistance gene mcr-1, which has recently been discovered in clinical and commensal isolates [35, 36], has revealed that this gene had already spread to the human gut microbiome of Chinese subjects several years ago [37]. While sequence-based studies provide huge amounts of data, they are limited to either identifying genes that are already known, or to predicting novel sequence functions based on high homology to known sequences. Annotation by sequence-based studies will keep increasing however, as studies using functional metagenomics keep identifying novel ARGs. Such studies have revealed a huge number of previously unknown ARGs present in environments such as soil [11,38-42] or activated sludge [43, 44], as well as in the microbiota of animals [45, 46] and humans [47-53].

Recent metagenomic studies have also uncovered that ARGs predominantly cluster by ecology, implying that the resistome in soils and wastewater treatment plants differ significantly from that of human pathogens $[54,55]$. Nonetheless, the authors of these works note that parts of these resistomes are shared [56] and stress the importance of continuing to explore the resistome of such environments. 
That commensals and the environment are important reservoirs for resistance is supported by several examples of ARGs on MGEs in human pathogens that appear to have originated from those reservoirs. A well-known example is that of the $b / a_{\mathrm{CTX}-\mathrm{M}}$ genes, which have become the most prevalent cause of extendedspectrum $\beta$-lactamases (ESBLS) in Enterobacteriaceae worldwide and a major cause of clinical treatment problems [57]. The potential origin of these genes was identified as the chromosomal DNA of various environmental Kluyvera species, from where they spread successfully to different bacterial species [58]. Shewanella algae, a marine and freshwater species, was found to be the origin of plasmid-encoded qnrA genes, conferring quinolone resistance [59], and different Vibrionaceae species might be the reservoir for other plasmid-encoded qnr genes [60], which have disseminated globally in various enterobacterial species, with exceptionally high prevalence rates in some areas [61]. The OXA-48-type carbapenem-hydrolysing $\beta$-lactamase genes, which are increasingly reported in enterobacterial species worldwide, were also found to originate from the chromosomes of waterborne, environmental Shewanella species [62]. As with these few examples, many clinically relevant resistance genes are believed to have originated from non-pathogenic bacteria, highlighting the immense potential of HGT to enable these pathogens to overcome human antibiotic use.

\section{Contribution of the various HGT mechanisms in the spread of ARGs}

\section{Conjugation}

Conjugation is the transfer of DNA through a multi-step process requiring cell to cell contact via cell surface pili or adhesins. It is facilitated by conjugative machinery which is encoded either by genes on autonomously replicating plasmids or by integrative conjugative elements in the chromosome [63, 64]. Additionally, this conjugative machinery may enable the mobilisation of plasmids that are non-conjugative, as observed for e.g. the exceptionally broad host range IncQ plasmids [65]. Of the various mechanisms that may facilitate HGT (Figure 1), conjugation is certainly the most commonly studied $[66,67]$.

ARGs are often associated with conjugative elements such as plasmids and transposons. While the transfer of these elements may also occur through transformation or transduction, conjugation is often considered as the most likely 
responsible mechanism. This is due to the fact that it provides better protection from the surrounding environment and a more efficient means of entering the host cell than transformation, while often having a broader host range than bacteriophage transduction. Moreover, while conjugation is a process directed towards the transfer of bacterial genes, transfer of bacterial DNA by transduction is a side-effect of erroneous bacteriophage replication [67].

The conjugation of MGEs conferring antimicrobial resistance has been observed in many types of ecosystems, ranging from transfer between bacteria in insects, soil, and water environments to various food and healthcare associated pathogens [68]. Importantly, transfer of plasmids and conjugative transposons, such as those of the Tn916 family, between unrelated bacteria over large taxonomic distances has been described [69-72], indicating that this mechanism contributes to the dissemination of ARGs between different reservoirs via such broad host range MGEs.

The spread of antibiotic resistance plasmids in human pathogens is especially well studied, and shows that once resistance genes have become established on successful plasmids, they can spread rapidly between strains, species, and even genera. This is well demonstrated by the bla $a_{\text {CTX-M }}$ ESBL genes, which have disseminated to various narrow and broad host range plasmids within Enterobacteriaceae, as well as to other opportunistic human pathogens [73]. These genes are now ubiquitous in humans [74], animals and the environment [75]. Furthermore, the transfer of plasmids in pathogens has led to the worldwide spread of numerous ARGs encoding resistance to $\beta$-lactams, quinolones, aminoglycosides, tetracyclines, sulfonamides, colistins and many other drug classes [76]. Of particular concern is the increasingly reported spread of plasmids harbouring carbapenem resistance [77] and the recent discovery of plasmidencoded colistin resistance in China [35], which has now already been identified at multiple continents [36] and may cause Enterobacteriaceae to truly become pan-drug resistant. Moreover multiple ARGs are often co-localised on the same plasmid, which allows for the relatively easy spread of multidrug resistance. 


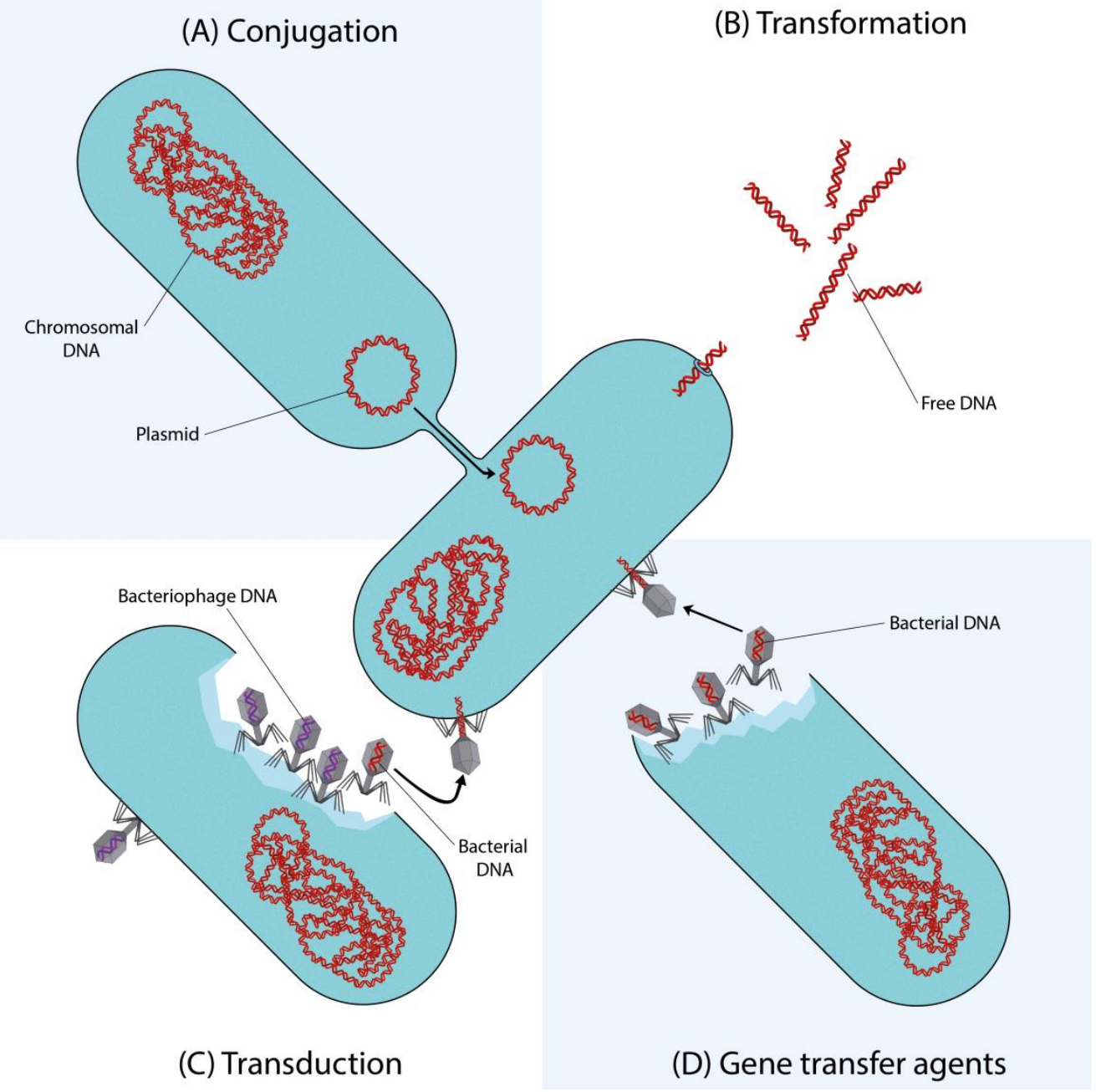

Figure 1: Mechanisms of horizontal gene transfer.

Each quadrant represents one different method of gene transfer. $(A)$ Conjugation is a process requiring cell to cell contact via cell surface pili or adhesins, through which DNA is transferred from the donor cell to the recipient cell. (B) Transformation is the uptake, integration, and functional expression of naked fragments of extracellular DNA. (C) Through specialized or generalized transduction, bacteriophages may transfer bacterial DNA from a previously infected donor cell to the recipient cell. During generalized transduction, bacterial DNA may be accidentally loaded into the phage head (shown as a phage with a red DNA strand). During specialized transduction, genomic DNA neighbouring the prophage DNA is co-excised and loaded into a new phage (not shown). (D) Gene transfer agents (GTAs) are bacteriophage-like particles that carry random pieces of the producing cell's genome. GTA particles may be released through cell lysis and spread to a recipient cell. 


\section{Transformation}

In 1928, Griffith became the first to demonstrate direct genetic exchange between different strains of Streptococcus pneumoniae [78]. Certain bacteria appeared to be capable of uptake, integration, and functional expression of naked fragments of extracellular DNA, a process called (natural) transformation. It soon became clear that bacteria could use transformation to evade antibiotics, by exchanging ARGs. In 1951, Hotchkiss induced penicillin and streptomycin resistance in previously sensitive strains of $S$. pneumoniae by exposing them to DNA from resistant strains [79]. Alexander et al. furthered this work by demonstrating intra- and inter-species transfer of streptomycin resistance between $H$. influenzae, $H$. parainfluenzae, and $H$. suis $[80,81]$.

In order for transformation to take place, several conditions have to be met. There must be DNA present in the extracellular environment; the recipient bacteria must be in a state of competence; and the translocated DNA must be stabilised, either by integration into the recipient genome, or by recircularisation (in the case of plasmid DNA) [82]. Whereas Neisseria spp. are considered to be constitutively competent $[83,84]$, other bacterial species capable of natural transformation may develop competence only under certain conditions, such as the presence of peptides or autoinducers, nutritional status, or other stressful conditions, as reviewed in more detail by Johnston et al. [84]. Importantly, studies have shown that exposure to antibiotics can induce competence in many species of bacteria, meaning that antibiotics would not only select for resistant strains, but also stimulate transformation of their ARGs [85-87].

In vitro experiments have done much to elucidate transformation of ARGs. Early work proved that ARGs could be transformed; to this end, streptomycin, rifampicin, erythromycin, nalidixic acid and kanamycin resistance have variously been transformed into Neisseria gonorrhoeae [83], Bacillus spp. [88], Gallibacterium anatis [89], and Streptococcus pneumoniae [87]. The introduction of molecular techniques allowed for the identification of the ARGs being transformed. In vitro studies have shown that the genes parC and gyrA are involved in the transformation of fluoroquinolone resistance between Streptococcus pneumoniae [90] and several viridans streptococci [91, 92], and that transformation of penA confers penicillin resistance in commensal Neisseria species ( $N$. flavescens and $N$. cinerea) and $N$. meningitidis [93].

Molecular techniques have also made it possible to look for evidence of transformation outside of the laboratory. Spratt et al. identified the penA variant 
responsible for penicillin resistance in clinical isolates of $N$. gonorrhoeae [94]; sequence analysis revealed a mosaic structure, with blocks homologous to susceptible-type penA and blocks that diverge significantly [95]. These 'resistant blocks' could be traced back to a strain of $N$. flavescens that had been isolated in the pre-antibiotic era, suggesting that such commensal species could have been the original source for the now ubiquitous resistance to penicillin [96, 97]. Mosaic genes are formed when sections of foreign DNA are incorporated into a recipient genome, as is the case in transformation. Their presence implies that HGT has taken place [98]. In streptococci, the mosaic penicillin-binding protein (PBP) genes that encode PBPs with decreased affinity for $\beta$-lactam antibiotics are believed to be the result of gene transfer from related penicillin-resistant species [99] and have disseminated penicillin resistance between various streptococcal species [100]. Studies of fluoroquinolone resistance have demonstrated that mosaic variants of the genes parC, parE and gyrA are readily transformed between $S$. pneumoniae, S. mitis and S. oralis [101], and between S. pyogenes and $S$. dysgalactiae [102].

Mao et al. developed a technique to extract intra- and extracellular DNA separately from environmental samples, and applied it to samples from a river basin in China. The result - a greater abundance of DNA outside of cells than inside - implies that in certain environments, extracellular DNA is a large reservoir for genes which may be accessible via transformation [103]. Furthermore, Domingues et al. demonstrated that MGEs such as transposons, integrons and gene cassettes can be disseminated efficiently between species, regardless of their level of genetic relatedness [104]. Similarly, streptococcal species have been shown to exchange conjugative transposons via transformation in addition to conjugation [105]. All of this indicates that transformation provides a broad capacity for the horizontal spread of resistance elements between divergent species. 


\section{Transduction}

Bacteriophages play an important role in shaping the bacterial microbiome in any environment. Through specialized or generalized transduction, bacteriophages can transfer genes that are advantageous to their microbial hosts, in turn promoting their own survival and dissemination [106]. The transferable DNA sequences range from chromosomal DNA to MGEs such as plasmids, transposons and genomic islands [107].

The mobilization or transfer of ARGs by bacteriophages has been documented for various bacterial species: the transduction of erythromycin [108], tetracycline or multiple resistances between strains of Streptococcus pyogenes [109]; the transfer of tetracycline and gentamicin resistance between enterococci [110]; the carriage of $\beta$-lactamase genes by bacteriophages in Escherichia coli [111] and Salmonella [112]; or the transfer of antibiotic resistance plasmids in MRSA [113].

Recent studies applying metagenomic approaches to samples from various environments have suggested that bacteriophages may play a bigger part in the spread of ARGs than previously recognized. Colomer-Lluch et al. used qPCR to show that the $\beta$-lactam ARGs $b / a_{\mathrm{TEM}}, b / a_{\mathrm{CTX}-\mathrm{M}}$ and $\operatorname{mec} A$ were present in bacteriophages from river and urban sewage water samples. Additionally, cloning of the phage DNA into ampicillin susceptible $E$. coli hosts resulted in resistant transformants, harbouring either the $b / a_{\mathrm{TEM}}, b / a_{\mathrm{CTX}-\mathrm{M}}$ or undetermined ARGs [114]. In another study, the presence of ARGs in bacteriophages was detected in respiratory tract DNA of cystic fibrosis patients [115]. Modi et al. demonstrated that treatment with antibiotics increased the number of ARGs in the intestinal phageome of mice and expanded the interactions between phage and bacterial species [106], which is an important observation considering the increased environmental exposure to antibiotics discussed earlier. Furthermore, several studies have used qPCR to detect ARGs in bacteriophages from wastewater samples [116, 117], animal and human faecal samples [118, 119], wastewater and sludge derived from wastewater treatment plants [120], and hospital and wastewater treatment plant effluents [121], indicating that bacteriophages are significant reservoirs of ARGs. Shousha et al. investigated bacteriophages isolated from chicken meat and found that about a quarter of the randomly isolated bacteriophages were able to transduce resistance to one or more antibiotics into an $E$. coli host. Moreover, they found a significant relationship between the presence of bacteriophages transducing kanamycin ARGs, and E. coli isolates 
resistant to kanamycin, implying a possible role of this mechanism in the spread of AMR [122].

Considering certain bacteriophages have been reported to have a wide host range that crosses between different species [110] or even different taxonomic classes [123], the observation of the plethora of ARGs carried by bacteriophages in various bacterial communities and environments provides renewed insights into the role of transduction in the dissemination of ARGs in microbial ecosystems.

\section{Gene transfer agents}

Gene transfer agents (GTAs), first identified in Rhodobacter capsulatus (RcGTA) in 1974 [124], are host-cell produced particles that resemble bacteriophage structures, capable of transferring genetic content. GTAs have several characteristic features: (i) rather than carrying DNA encoding their own machinery (as with self-propagating bacteriophages), GTAs carry random pieces of the producing cell's genome [124-127]; (ii) the amount of DNA packaged by the GTAs is insufficient to encode all of their protein components, making them unable to self-propagate [128-130]; (iii) GTA production is controlled by cell regulatory mechanisms [130-133]; (iv) GTA particles are released through cell lysis [126, 134] although cultures do not display observable lysis [124] as only a small subpopulation of GTA-producing cultures ( $\sim 3 \%)$ is responsible for $\sim 95 \%$ of GTA release $[126,135]$; $(v)$ recently, it has been proposed that GTAs combine key aspects of transduction and transformation for cell entry, requiring proteins involved in natural transformation [136].

Although GTA particles do not necessarily carry any GTA-encoding genes [137], RcGTA-like gene clusters are widespread in alphaproteobacteria, especially in the Rhodobacterales: a complete set of RcGTA-like structural genes has been demonstrated in nearly every sequenced member of the Rhodobacterales [128, 137]. Moreover, two species in the order of Rhodobacterales, Roseovarius nubinhibens and Ruegeria mobilis, are known to produce GTAs, and there is evidence of GTA production in Ruegeria pomeroyi [137-139]. Other known GTAs are VSH-1 in the spirochaete Brachyspira hyodysenteriae, Dd1 in the deltaproteobacterium Desulfovibrio desulfuricans, and VTA in the archaeon Methanococcus voltae [128, 137]. The genes required for GTA-production are contained within the host genome and appear to have been propagated through vertical transmission [128]. 
It has been suggested that GTAs have several advantages over the previously described mechanisms of HGT [125]: GTA particles afford DNA protection from damaging environmental factors, as opposed to the naked DNA involved in natural transformation; compared to conjugation, the transfer ability of GTAs is likely maintained after conditions killing the host cell, and is moreover not constrained by cell-to-cell contact; lastly, compared to transduction, GTA particles predominantly carry random pieces of host genome, rather than mostly bacteriophage DNA. In the marine environment, GTA-mediated transfer events have been reported to be remarkably high; up to several million times higher than previous estimates of HGT in marine environments, exceeding previously described transformation and transduction frequencies [138]. Moreover, genes can be exchanged between bacterial phyla [137, 138], suggesting the possible widespread contribution of GTAs in shaping and driving adaptation of the natural environment.

In culture, GTA mediated transfer of antibiotic resistance markers has been readily demonstrated in Rhodobacter capsulatus [124, 140, 141] and the spirochaete Brachyspira hyodesenteriae [142, 143]. Moreover, GTAs have been used to transfer traits from plasmids [144]. In addition, the Brachyspira hyodesenteriae GTA VSH-1 can be induced by certain antibiotics [142], which points out its possible impact in its natural environment, the swine intestinal tract. Other Brachyspira spp. occur in the intestinal tract of other species, including humans and chickens [145], in which VSH-1 genes have been described [146]. However, interspecies GTA-mediated transfer remains to be demonstrated [146].

The impact of GTAs on human health has yet to be established, but given the high frequency of transfer events in certain environments, and their ability to exchange genes between phyla, their potential to act as vehicles of resistance traits in the environment, and within the microbiota of humans and farmed animals is an area worthy of further study. 


\section{Conclusion}

The unprecedented increase in environmental levels of antibiotics, driven by medical and agricultural demand has disrupted the natural balance between microbes and antimicrobials. The effects this has on microbial communities are wide-ranging, and the result is an increasingly tangible threat to healthcare, as resistance to all known antibiotics disseminates rapidly around the globe. Our understanding of the interactions between antimicrobials and resistance against it, observed not only in the clinic but across different ecosystems around the world, is increasing rapidly and has provided valuable insights. However, it is vital that we continue to unravel the extent of, and dissemination between resistomes of these microbial ecosystems, as any attempt at coming to terms with the antimicrobial resistance problem will have to account for these vast reservoirs of ARGs. 


\section{References}

1. Nordmann P, Dortet L, Poirel L. Carbapenem resistance in Enterobacteriaceae: here is the storm! Trends Mol Med. 2012;18(5):263-72.

2. Barlow M, Hall BG. Phylogenetic analysis shows that the OXA beta-lactamase genes have been on plasmids for millions of years. J Mol Evol. 2002;55(3):314-21.

3. Bhullar K, Waglechner N, Pawlowski A, Koteva K, Banks ED, Johnston MD, et al. Antibiotic resistance is prevalent in an isolated cave microbiome. PLoS ONE. 2012;7(4):e34953.

4. Wright GD, Poinar $\mathrm{H}$. Antibiotic resistance is ancient: implications for drug discovery. Trends Microbiol. 2012;20(4):157-9.

5. Hall BG, Barlow M. Evolution of the serine beta-lactamases: past, present and future. Drug Resist Updat. 2004;7(2):111-23.

6. Aminov RI. The role of antibiotics and antibiotic resistance in nature. Environ Microbiol. 2009;11(12):2970-88.

7. Martinez JL. Antibiotics and antibiotic resistance genes in natural environments. Science. 2008;321(5887):365-7.

8. Linares JF, Gustafsson I, Baquero F, Martinez JL. Antibiotics as intermicrobial signaling agents instead of weapons. Proc Natl Acad Sci U S A. 2006;103(51):19484-9.

9. Davies J. Are antibiotics naturally antibiotics? J Ind Microbiol Biotechnol. 2006;33(7):496-9.

10. D'Costa VM, King CE, Kalan L, Morar M, Sung WW, Schwarz C, et al. Antibiotic resistance is ancient. Nature. 2011;477(7365):457-61.

11. Perron GG, Whyte L, Turnbaugh PJ, Goordial J, Hanage WP, Dantas G, et al. Functional characterization of bacteria isolated from ancient arctic soil exposes diverse resistance mechanisms to modern antibiotics. PLoS ONE. 2015;10(3):e0069533.

12. Van Boeckel TP, Gandra S, Ashok A, Caudron Q, Grenfell BT, Levin SA, et al. Global antibiotic consumption 2000 to 2010: an analysis of national pharmaceutical sales data. Lancet Infect Dis. 2014;14(8):742-50.

13. Van Boeckel TP, Brower C, Gilbert M, Grenfell BT, Levin SA, Robinson TP, et al. Global trends in antimicrobial use in food animals. Proc Natl Acad Sci U S A. 2015;112(18):5649-54.

14. Cabello FC. Heavy use of prophylactic antibiotics in aquaculture: a growing problem for human and animal health and for the environment. Environ Microbiol. 2006;8(7):1137-44.

15. Economou V, Gousia P. Agriculture and food animals as a source of antimicrobialresistant bacteria. Infect Drug Resist. 2015;8:49-61.

16. Penders J, Stobberingh EE. Antibiotic resistance of motile aeromonads in indoor catfish and eel farms in the southern part of The Netherlands. Int J Antimicrob Agents. 2008;31(3):261-5.

17. Sarmah AK, Meyer MT, Boxall AB. A global perspective on the use, sales, exposure pathways, occurrence, fate and effects of veterinary antibiotics (VAs) in the environment. Chemosphere. 2006;65(5):725-59. 
18. Zhang XX, Zhang T, Zhang M, Fang HH, Cheng SP. Characterization and quantification of class 1 integrons and associated gene cassettes in sewage treatment plants. Appl Microbiol Biotechnol. 2009;82(6):1169-77.

19. Tennstedt T, Szczepanowski R, Braun S, Puhler A, Schluter A. Occurrence of integronassociated resistance gene cassettes located on antibiotic resistance plasmids isolated from a wastewater treatment plant. FEMS Microbiol Ecol. 2003;45(3):23952.

20. Graham DW, Olivares-Rieumont S, Knapp CW, Lima L, Werner D, Bowen E. Antibiotic resistance gene abundances associated with waste discharges to the Almendares River near Havana, Cuba. Environ Sci Technol. 2011;45(2):418-24.

21. Martinez JL. Environmental pollution by antibiotics and by antibiotic resistance determinants. Environ Pollut. 2009;157(11):2893-902.

22. Le-Minh N, Khan SJ, Drewes JE, Stuetz RM. Fate of antibiotics during municipal water recycling treatment processes. Water Res. 2010;44(15):4295-323.

23. Watkinson AJ, Murby EJ, Costanzo SD. Removal of antibiotics in conventional and advanced wastewater treatment: implications for environmental discharge and wastewater recycling. Water Res. 2007;41(18):4164-76.

24. Larsson DG, de Pedro C, Paxeus N. Effluent from drug manufactures contains extremely high levels of pharmaceuticals. J Hazard Mater. 2007;148(3):751-5.

25. Fick J, Soderstrom H, Lindberg RH, Phan C, Tysklind M, Larsson DG. Contamination of surface, ground, and drinking water from pharmaceutical production. Environ Toxicol Chem. 2009;28(12):2522-7.

26. Marathe NP, Regina VR, Walujkar SA, Charan SS, Moore ER, Larsson DG, et al. A treatment plant receiving waste water from multiple bulk drug manufacturers is a reservoir for highly multi-drug resistant integron-bearing bacteria. PLOS ONE. 2013;8(10):e77310.

27. Kristiansson E, Fick J, Janzon A, Grabic R, Rutgersson C, Weijdegard B, et al. Pyrosequencing of antibiotic-contaminated river sediments reveals high levels of resistance and gene transfer elements. PLoS ONE. 2011;6(2):e17038.

28. Knapp CW, Dolfing J, Ehlert PA, Graham DW. Evidence of increasing antibiotic resistance gene abundances in archived soils since 1940. Environ Sci Technol. 2010;44(2):580-7.

29. Datta N, Hughes VM. Plasmids of the same Inc groups in Enterobacteria before and after the medical use of antibiotics. Nature. 1983;306(5943):616-7.

30. Penders J, Stobberingh EE, Savelkoul PH, Wolffs PF. The human microbiome as a reservoir of antimicrobial resistance. Front Microbiol. 2013;4:87.

31. Rizzo L, Manaia C, Merlin C, Schwartz T, Dagot C, Ploy MC, et al. Urban wastewater treatment plants as hotspots for antibiotic resistant bacteria and genes spread into the environment: a review. Sci Total Environ. 2013;447:345-60.

32. Pehrsson EC, Forsberg KJ, Gibson MK, Ahmadi S, Dantas G. Novel resistance functions uncovered using functional metagenomic investigations of resistance reservoirs. Front Microbiol. 2013;4:145.

33. von Wintersdorff CJ, Penders J, Stobberingh EE, Oude Lashof AM, Hoebe CJ, Savelkoul PH, et al. High rates of antimicrobial drug resistance gene acquisition after international travel, The Netherlands. Emerg Infect Dis. 2014;20(4):649-57. 
34. Wright GD. Antibiotic resistance in the environment: a link to the clinic? Curr Opin Microbiol. 2010;13(5):589-94.

35. Liu YY, Wang Y, Walsh TR, Yi LX, Zhang R, Spencer J, et al. Emergence of plasmidmediated colistin resistance mechanism MCR-1 in animals and human beings in China: a microbiological and molecular biological study. Lancet Infect Dis. 2016;16(2):161-8.

36. Arcilla MS, van Hattem JM, Matamoros S, Melles DC, Penders J, de Jong MD, et al. Dissemination of the mcr-1 colistin resistance gene. Lancet Infect Dis. 2015.

37. Hu Y, Liu F, Lin IY, Gao GF, Zhu B. Dissemination of the mcr-1 colistin resistance gene. Lancet Infect Dis. 2015.

38. D'Costa VM, McGrann KM, Hughes DW, Wright GD. Sampling the antibiotic resistome. Science. 2006;311(5759):374-7.

39. Allen HK, Moe LA, Rodbumrer J, Gaarder A, Handelsman J. Functional metagenomics reveals diverse beta-lactamases in a remote Alaskan soil. ISME J. 2009;3(2):243-51.

40. Donato JJ, Moe LA, Converse BJ, Smart KD, Berklein FC, McManus PS, et al. Metagenomic analysis of apple orchard soil reveals antibiotic resistance genes encoding predicted bifunctional proteins. Appl Environ Microbiol. 2010;76(13):4396401.

41. Riesenfeld CS, Goodman RM, Handelsman J. Uncultured soil bacteria are a reservoir of new antibiotic resistance genes. Environ Microbiol. 2004;6(9):981-9.

42. Torres-Cortes G, Millan V, Ramirez-Saad HC, Nisa-Martinez R, Toro N, MartinezAbarca F. Characterization of novel antibiotic resistance genes identified by functional metagenomics on soil samples. Environ Microbiol. 2011;13(4):1101-14.

43. Mori T, Mizuta S, Suenaga H, Miyazaki K. Metagenomic screening for bleomycin resistance genes. Appl Environ Microbiol. 2008;74(21):6803-5.

44. Parsley LC, Consuegra EJ, Kakirde KS, Land AM, Harper WF, Jr., Liles MR. Identification of diverse antimicrobial resistance determinants carried on bacterial, plasmid, or viral metagenomes from an activated sludge microbial assemblage. Appl Environ Microbiol. 2010;76(11):3753-7.

45. Kazimierczak KA, Scott KP, Kelly D, Aminov RI. Tetracycline resistome of the organic pig gut. Appl Environ Microbiol. 2009;75(6):1717-22.

46. Wichmann F, Udikovic-Kolic N, Andrew S, Handelsman J. Diverse antibiotic resistance genes in dairy cow manure. MBio. 2014;5(2):e01017.

47. Cheng G, Hu Y, Yin Y, Yang X, Xiang C, Wang B, et al. Functional screening of antibiotic resistance genes from human gut microbiota reveals a novel gene fusion. FEMS Microbiol Lett. 2012;336(1):11-6.

48. Sommer MO, Dantas G, Church GM. Functional characterization of the antibiotic resistance reservoir in the human microflora. Science. 2009;325(5944):1128-31.

49. Card RM, Warburton PJ, MacLaren N, Mullany P, Allan E, Anjum MF. Application of microarray and functional-based screening methods for the detection of antimicrobial resistance genes in the microbiomes of healthy humans. PLoS ONE. 2014;9(1):e86428.

50. Clemente JC, Pehrsson EC, Blaser MJ, Sandhu K, Gao Z, Wang B, et al. The microbiome of uncontacted Amerindians. Sci Adv. 2015;1(3). 
51. Fouhy F, Ogilvie LA, Jones BV, Ross RP, Ryan AC, Dempsey EM, et al. Identification of aminoglycoside and beta-lactam resistance genes from within an infant gut functional metagenomic library. PLoS ONE. 2014;9(9):e108016.

52. Moore AM, Ahmadi S, Patel S, Gibson MK, Wang B, Ndao MI, et al. Gut resistome development in healthy twin pairs in the first year of life. Microbiome. 2015;3:27.

53. Moore AM, Patel S, Forsberg KJ, Wang B, Bentley G, Razia Y, et al. Pediatric fecal microbiota harbor diverse and novel antibiotic resistance genes. PLoS ONE. 2013;8(11):e78822.

54. Gibson MK, Forsberg KJ, Dantas G. Improved annotation of antibiotic resistance determinants reveals microbial resistomes cluster by ecology. ISME J. 2015;9(1):20716.

55. Munck C, Albertsen M, Telke A, Ellabaan M, Nielsen PH, Sommer MO. Limited dissemination of the wastewater treatment plant core resistome. Nat Commun. 2015;6:8452.

56. Forsberg KJ, Reyes A, Wang B, Selleck EM, Sommer MO, Dantas G. The shared antibiotic resistome of soil bacteria and human pathogens. Science. 2012;337(6098):1107-11.

57. Hawkey PM, Jones AM. The changing epidemiology of resistance. J Antimicrob Chemother. 2009;64 Suppl 1:i3-10.

58. Canton R, Coque TM. The CTX-M beta-lactamase pandemic. Curr Opin Microbiol. 2006;9(5):466-75.

59. Poirel L, Rodriguez-Martinez JM, Mammeri H, Liard A, Nordmann P. Origin of plasmid-mediated quinolone resistance determinant QnrA. Antimicrob Agents Chemother. 2005;49(8):3523-5.

60. Poirel L, Liard A, Rodriguez-Martinez JM, Nordmann P. Vibrionaceae as a possible source of Qnr-like quinolone resistance determinants. J Antimicrob Chemother. 2005;56(6):1118-21.

61. Vien le TM, Minh NN, Thuong TC, Khuong HD, Nga TV, Thompson C, et al. The coselection of fluoroquinolone resistance genes in the gut flora of Vietnamese children. PLoS ONE. 2012;7(8):e42919.

62. Poirel L, Potron A, Nordmann P. OXA-48-like carbapenemases: the phantom menace. J Antimicrob Chemother. 2012;67(7):1597-606.

63. Smillie C, Garcillan-Barcia MP, Francia MV, Rocha EP, de la Cruz F. Mobility of plasmids. Microbiol Mol Biol Rev. 2010;74(3):434-52.

64. Wozniak RA, Waldor MK. Integrative and conjugative elements: mosaic mobile genetic elements enabling dynamic lateral gene flow. Nat Rev Microbiol. 2010;8(8):552-63.

65. Meyer R. Replication and conjugative mobilization of broad host-range IncQ plasmids. Plasmid. 2009;62(2):57-70.

66. Guglielmini J, de la Cruz F, Rocha EP. Evolution of conjugation and type IV secretion systems. Mol Biol Evol. 2013;30(2):315-31.

67. Norman A, Hansen LH, Sorensen SJ. Conjugative plasmids: vessels of the communal gene pool. Philos Trans R Soc Lond B Biol Sci. 2009;364(1527):2275-89.

68. Davison J. Genetic exchange between bacteria in the environment. Plasmid. 1999;42(2):73-91. 
69. Musovic S, Oregaard G, Kroer N, Sorensen SJ. Cultivation-independent examination of horizontal transfer and host range of an IncP-1 plasmid among gram-positive and gram-negative bacteria indigenous to the barley rhizosphere. Appl Environ Microbiol. 2006;72(10):6687-92.

70. Tamminen M, Virta M, Fani R, Fondi M. Large-scale analysis of plasmid relationships through gene-sharing networks. Mol Biol Evol. 2012;29(4):1225-40.

71. Shoemaker NB, Vlamakis $H$, Hayes $K$, Salyers AA. Evidence for extensive resistance gene transfer among Bacteroides spp. and among Bacteroides and other genera in the human colon. Appl Environ Microbiol. 2001;67(2):561-8.

72. Roberts AP, Mullany P. A modular master on the move: the Tn916 family of mobile genetic elements. Trends Microbiol. 2009;17(6):251-8.

73. Canton R, Gonzalez-Alba JM, Galan JC. CTX-M Enzymes: Origin and Diffusion. Front Microbiol. 2012;3:110.

74. Woerther PL, Burdet C, Chachaty E, Andremont A. Trends in human fecal carriage of extended-spectrum beta-lactamases in the community: toward the globalization of CTX-M. Clin Microbiol Rev. 2013;26(4):744-58.

75. Hartmann A, Locatelli A, Amoureux L, Depret G, Jolivet C, Gueneau E, et al. Occurrence of CTX-M Producing Escherichia coli in Soils, Cattle, and Farm Environment in France (Burgundy Region). Front Microbiol. 2012;3:83.

76. Huddleston JR. Horizontal gene transfer in the human gastrointestinal tract: potential spread of antibiotic resistance genes. Infect Drug Resist. 2014;7:167-76.

77. Carattoli A. Plasmids and the spread of resistance. Int J Med Microbiol. 2013;303(67):298-304.

78. Griffith F. The Significance of Pneumococcal Types. J Hyg (Lond). 1928;27(2):113-59.

79. Hotchkiss RD. Transfer of penicillin resistance in pneumococci by the desoxyribonucleate derived from resistant cultures. Cold Spring Harb Symp Quant Biol. 1951;16:457-61.

80. Alexander HE, Hahn E, Leidy G. On the specificity of the desoxyribonucleic acid which induces streptomycin resistance in Hemophilus. J Exp Med. 1956;104(3):305-20.

81. Alexander HE, Leidy G. Induction of streptomycin resistance in sensitive Hemophilus influenzae by extracts containing desoxyribonucleic acid from resistant Hemophilus influenzae. J Exp Med. 1953;97(1):17-31.

82. Thomas CM, Nielsen KM. Mechanisms of, and barriers to, horizontal gene transfer between bacteria. Nat Rev Microbiol. 2005;3(9):711-21.

83. Sparling PF. Genetic transformation of Neisseria gonorrhoeae to streptomycin resistance. J Bacteriol. 1966;92(5):1364-71.

84. Johnston C, Martin B, Fichant G, Polard P, Claverys JP. Bacterial transformation: distribution, shared mechanisms and divergent control. Nat Rev Microbiol. 2014;12(3):181-96.

85. Charpentier X, Kay E, Schneider D, Shuman HA. Antibiotics and UV radiation induce competence for natural transformation in Legionella pneumophila. J Bacteriol. 2011;193(5):1114-21.

86. Charpentier X, Polard P, Claverys JP. Induction of competence for genetic transformation by antibiotics: convergent evolution of stress responses in distant bacterial species lacking SOS? Curr Opin Microbiol. 2012;15(5):570-6. 
87. Prudhomme M, Attaiech L, Sanchez G, Martin B, Claverys JP. Antibiotic stress induces genetic transformability in the human pathogen Streptococcus pneumoniae. Science. 2006;313(5783):89-92.

88. Harford N, Mergeay M. Interspecific transformation of rifampicin resistance in the genus Bacillus. Mol Gen Genet. 1973;120(2):151-5.

89. Kristensen BM, Sinha S, Boyce JD, Bojesen AM, Mell JC, Redfield RJ. Natural transformation of Gallibacterium anatis. Appl Environ Microbiol. 2012;78(14):491422.

90. Ferrandiz MJ, Fenoll A, Linares J, De La Campa AG. Horizontal transfer of parC and gyrA in fluoroquinolone-resistant clinical isolates of Streptococcus pneumoniae. Antimicrob Agents Chemother. 2000;44(4):840-7.

91. Gonzalez I, Georgiou M, Alcaide F, Balas D, Linares J, de la Campa AG. Fluoroquinolone resistance mutations in the parC, parE, and gyrA genes of clinical isolates of viridans group streptococci. Antimicrob Agents Chemother. 1998;42(11):2792-8.

92. Janoir C, Podglajen I, Kitzis MD, Poyart C, Gutmann L. In vitro exchange of fluoroquinolone resistance determinants between Streptococcus pneumoniae and viridans streptococci and genomic organization of the parE-parC region in S. mitis. J Infect Dis. 1999;180(2):555-8.

93. Bowler LD, Zhang QY, Riou JY, Spratt BG. Interspecies recombination between the penA genes of Neisseria meningitidis and commensal Neisseria species during the emergence of penicillin resistance in N. meningitidis: natural events and laboratory simulation. J Bacteriol. 1994;176(2):333-7.

94. Spratt BG. Hybrid penicillin-binding proteins in penicillin-resistant strains of Neisseria gonorrhoeae. Nature. 1988;332(6160):173-6.

95. Spratt BG, Bowler LD, Zhang QY, Zhou J, Smith JM. Role of interspecies transfer of chromosomal genes in the evolution of penicillin resistance in pathogenic and commensal Neisseria species. J Mol Evol. 1992;34(2):115-25.

96. Lujan R, Zhang QY, Saez Nieto JA, Jones DM, Spratt BG. Penicillin-resistant isolates of Neisseria lactamica produce altered forms of penicillin-binding protein 2 that arose by interspecies horizontal gene transfer. Antimicrob Agents Chemother. 1991;35(2):300-4.

97. Spratt BG, Zhang QY, Jones DM, Hutchison A, Brannigan JA, Dowson CG. Recruitment of a penicillin-binding protein gene from Neisseria flavescens during the emergence of penicillin resistance in Neisseria meningitidis. Proc Natl Acad Sci U S A. 1989;86(22):8988-92.

98. Hakenbeck R. Mosaic genes and their role in penicillin-resistant Streptococcus pneumoniae. Electrophoresis. 1998;19(4):597-601.

99. Sibold C, Henrichsen J, Konig A, Martin C, Chalkley L, Hakenbeck R. Mosaic pbpX genes of major clones of penicillin-resistant Streptococcus pneumoniae have evolved from pbpX genes of a penicillin-sensitive Streptococcus oralis. Mol Microbiol. 1994;12(6):1013-23.

100. Dowson CG, Hutchison A, Woodford N, Johnson AP, George RC, Spratt BG. Penicillinresistant viridans streptococci have obtained altered penicillin-binding protein genes from penicillin-resistant strains of Streptococcus pneumoniae. Proc Natl Acad Sci U S A. 1990;87(15):5858-62. 
101. Balsalobre L, Ferrandiz MJ, Linares J, Tubau F, de la Campa AG. Viridans group streptococci are donors in horizontal transfer of topoisomerase IV genes to Streptococcus pneumoniae. Antimicrob Agents Chemother. 2003;47(7):2072-81.

102. Pletz MW, McGee L, Van Beneden CA, Petit S, Bardsley M, Barlow M, et al. Fluoroquinolone resistance in invasive Streptococcus pyogenes isolates due to spontaneous mutation and horizontal gene transfer. Antimicrob Agents Chemother. 2006;50(3):943-8.

103. Mao D, Luo Y, Mathieu J, Wang Q, Feng L, Mu Q, et al. Persistence of extracellular DNA in river sediment facilitates antibiotic resistance gene propagation. Environ Sci Technol. 2014;48(1):71-8.

104. Domingues S, Harms K, Fricke WF, Johnsen PJ, da Silva GJ, Nielsen KM. Natural transformation facilitates transfer of transposons, integrons and gene cassettes between bacterial species. PLoS Pathog. 2012;8(8):e1002837.

105. Chancey ST, Agrawal S, Schroeder MR, Farley MM, Tettelin H, Stephens DS. Composite mobile genetic elements disseminating macrolide resistance in Streptococcus pneumoniae. Front Microbiol. 2015;6:26.

106. Modi SR, Lee HH, Spina CS, Collins JJ. Antibiotic treatment expands the resistance reservoir and ecological network of the phage metagenome. Nature. 2013;499(7457):219-22.

107. Brown-Jaque M, Calero-Caceres W, Muniesa M. Transfer of antibiotic-resistance genes via phage-related mobile elements. Plasmid. 2015;79:1-7.

108. Hyder SL, Streitfeld MM. Transfer of erythromycin resistance from clinically isolated lysogenic strains of Streptococcus pyogenes via their endogenous phage. J Infect Dis. 1978;138(3):281-6.

109. Ubukata K, Konno M, Fujii R. Transduction of drug resistance to tetracycline, chloramphenicol, macrolides, lincomycin and clindamycin with phages induced from Streptococcus pyogenes. J Antibiot (Tokyo). 1975;28(9):681-8.

110. Mazaheri Nezhad Fard R, Barton MD, Heuzenroeder MW. Bacteriophage-mediated transduction of antibiotic resistance in enterococci. Lett Appl Microbiol. 2011;52(6):559-64.

111. Billard-Pomares T, Fouteau S, Jacquet ME, Roche D, Barbe V, Castellanos M, et al. Characterization of a P1-like bacteriophage carrying an SHV-2 extended-spectrum beta-lactamase from an Escherichia coli strain. Antimicrob Agents Chemother. 2014;58(11):6550-7.

112. Schmieger $H$, Schicklmaier P. Transduction of multiple drug resistance of Salmonella enterica serovar typhimurium DT104. FEMS Microbiol Lett. 1999;170(1):251-6.

113. Varga M, Kuntova L, Pantucek R, Maslanova I, Ruzickova V, Doskar J. Efficient transfer of antibiotic resistance plasmids by transduction within methicillin-resistant Staphylococcus aureus USA300 clone. FEMS Microbiol Lett. 2012;332(2):146-52.

114. Colomer-Lluch $M$, Jofre J, Muniesa $M$. Antibiotic resistance genes in the bacteriophage DNA fraction of environmental samples. PLoS ONE. 2011;6(3):e17549.

115. Rolain JM, Fancello L, Desnues C, Raoult D. Bacteriophages as vehicles of the resistome in cystic fibrosis. J Antimicrob Chemother. 2011;66(11):2444-7.

116. Colomer-Lluch M, Calero-Caceres W, Jebri S, Hmaied F, Muniesa M, Jofre J. Antibiotic resistance genes in bacterial and bacteriophage fractions of Tunisian and Spanish 
wastewaters as markers to compare the antibiotic resistance patterns in each population. Environ Int. 2014;73:167-75.

117. Colomer-Lluch M, Jofre J, Muniesa M. Quinolone resistance genes (qnrA and qnrS) in bacteriophage particles from wastewater samples and the effect of inducing agents on packaged antibiotic resistance genes. J Antimicrob Chemother. 2014;69(5):126574.

118. Quiros P, Colomer-Lluch M, Martinez-Castillo A, Miro E, Argente M, Jofre J, et al. Antibiotic resistance genes in the bacteriophage DNA fraction of human fecal samples. Antimicrob Agents Chemother. 2014;58(1):606-9.

119. Colomer-Lluch M, Imamovic L, Jofre J, Muniesa M. Bacteriophages carrying antibiotic resistance genes in fecal waste from cattle, pigs, and poultry. Antimicrob Agents Chemother. 2011;55(10):4908-11.

120. Calero-Caceres W, Melgarejo A, Colomer-Lluch M, Stoll C, Lucena F, Jofre J, et al. Sludge as a potential important source of antibiotic resistance genes in both the bacterial and bacteriophage fractions. Environ Sci Technol. 2014;48(13):7602-11.

121. Marti E, Variatza E, Balcazar JL. Bacteriophages as a reservoir of extended-spectrum beta-lactamase and fluoroquinolone resistance genes in the environment. Clin Microbiol Infect. 2014;20(7):0456-9.

122. Shousha A, Awaiwanont N, Sofka D, Smulders FJ, Paulsen P, Szostak MP, et al. Bacteriophages Isolated from Chicken Meat and the Horizontal Transfer of Antimicrobial Resistance Genes. Appl Environ Microbiol. 2015;81(14):4600-6.

123. Jensen EC, Schrader HS, Rieland B, Thompson TL, Lee KW, Nickerson KW, et al. Prevalence of broad-host-range lytic bacteriophages of Sphaerotilus natans, Escherichia coli, and Pseudomonas aeruginosa. Appl Environ Microbiol. 1998;64(2):575-80.

124. Marrs B. Genetic recombination in Rhodopseudomonas capsulata. Proc Natl Acad Sci U S A. 1974;71(3):971-3.

125. Stanton TB. Prophage-like gene transfer agents-novel mechanisms of gene exchange for Methanococcus, Desulfovibrio, Brachyspira, and Rhodobacter species. Anaerobe. 2007;13(2):43-9.

126. Hynes AP, Mercer RG, Watton DE, Buckley CB, Lang AS. DNA packaging bias and differential expression of gene transfer agent genes within a population during production and release of the Rhodobacter capsulatus gene transfer agent, RcGTA. Mol Microbiol. 2012;85(2):314-25.

127. Humphrey SB, Stanton TB, Jensen NS, Zuerner RL. Purification and characterization of VSH-1, a generalized transducing bacteriophage of Serpulina hyodysenteriae. J Bacteriol. 1997;179(2):323-9.

128. Lang AS, Beatty JT. Importance of widespread gene transfer agent genes in alphaproteobacteria. Trends Microbiol. 2007;15(2):54-62.

129. Lang AS, Beatty JT. The gene transfer agent of Rhodobacter capsulatus and "constitutive transduction" in prokaryotes. Arch Microbiol. 2001;175(4):241-9.

130. Lang AS, Beatty JT. Genetic analysis of a bacterial genetic exchange element: the gene transfer agent of Rhodobacter capsulatus. Proceedings of the National Academy of Sciences of the United States of America. 2000;97(2):859-64.

131. Brimacombe CA, Ding H, Beatty JT. Rhodobacter capsulatus DprA is essential for RecA-mediated gene transfer agent (RcGTA) recipient capability regulated by 
quorum-sensing and the CtrA response regulator. Mol Microbiol. 2014;92(6):126078.

132. Mercer RG, Quinlan M, Rose AR, Noll S, Beatty JT, Lang AS. Regulatory systems controlling motility and gene transfer agent production and release in Rhodobacter capsulatus. FEMS Microbiol Lett. 2012;331(1):53-62.

133. Leung MM, Brimacombe CA, Spiegelman GB, Beatty JT. The GtaR protein negatively regulates transcription of the gtaRI operon and modulates gene transfer agent (RcGTA) expression in Rhodobacter capsulatus. Mol Microbiol. 2012;83(4):759-74.

134. Westbye $A B$, Leung MM, Florizone SM, Taylor $T A$, Johnson JA, Fogg $P C$, et al. Phosphate concentration and the putative sensor kinase protein CckA modulate cell lysis and release of the Rhodobacter capsulatus gene transfer agent. J Bacteriol. 2013;195(22):5025-40.

135. Fogg PC, Westbye $A B$, Beatty JT. One for all or all for one: heterogeneous expression and host cell lysis are key to gene transfer agent activity in Rhodobacter capsulatus. PLoS ONE. 2012;7(8):e43772.

136. Brimacombe CA, Ding $H$, Johnson JA, Beatty JT. Homologues of Genetic Transformation DNA Import Genes Are Required for Rhodobacter capsulatus Gene Transfer Agent Recipient Capability Regulated by the Response Regulator CtrA. J Bacteriol. 2015;197(16):2653-63.

137. Lang AS, Zhaxybayeva O, Beatty JT. Gene transfer agents: phage-like elements of genetic exchange. Nat Rev Microbiol. 2012;10(7):472-82.

138. McDaniel LD, Young E, Delaney J, Ruhnau F, Ritchie KB, Paul JH. High frequency of horizontal gene transfer in the oceans. Science. 2010;330(6000):50.

139. Biers EJ, Wang K, Pennington C, Belas R, Chen F, Moran MA. Occurrence and expression of gene transfer agent genes in marine bacterioplankton. Appl Environ Microbiol. 2008;74(10):2933-9.

140. Wall JD, Weaver PF, Gest H. Gene transfer agents, bacteriophages, and bacteriocins of Rhodopseudomonas capsulata. Arch Microbiol. 1975;105(3):217-24.

141. Solioz M, Yen HC, Marris B. Release and uptake of gene transfer agent by Rhodopseudomonas capsulata. J Bacteriol. 1975;123(2):651-7.

142. Stanton TB, Humphrey SB, Sharma VK, Zuerner RL. Collateral effects of antibiotics: carbadox and metronidazole induce VSH-1 and facilitate gene transfer among Brachyspira hyodysenteriae strains. Appl Environ Microbiol. 2008;74(10):2950-6.

143. Stanton TB, Matson EG, Humphrey SB. Brachyspira (Serpulina) hyodysenteriae gyrB mutants and interstrain transfer of coumermycin $A(1)$ resistance. Appl Environ Microbiol. 2001;67(5):2037-43.

144. Scolnik PA, Haselkorn R. Activation of extra copies of genes coding for nitrogenase in Rhodopseudomonas capsulata. Nature. 1984;307(5948):289-92.

145. Hampson DJ, Ahmed N. Spirochaetes as intestinal pathogens: lessons from a Brachyspira genome. Gut Pathog. 2009;1(1):10.

146. Motro Y, La T, Bellgard MI, Dunn DS, Phillips ND, Hampson DJ. Identification of genes associated with prophage-like gene transfer agents in the pathogenic intestinal spirochaetes Brachyspira hyodysenteriae, Brachyspira pilosicoli and Brachyspira intermedia. Vet Microbiol. 2009;134(3-4):340-5. 


\section{Chapter 3}

\section{The gut resistome is highly dynamic during the first months of life}

Christian J.H. von Wintersdorff, Petra F.G. Wolffs, Paul H.M. Savelkoul, Rianne R.R. Nijsen, Susanne Lau, Kerstin Gerhold, Eckard Hamelmann \& John Penders

Future Microbiol. 2016 Apr;11:501-10 


\section{Abstract}

\section{Aim:}

We investigated the longitudinal development of several antibiotic resistance genes (ARGs) of the infant gut resistome during the first months after birth.

\section{Materials \& methods:}

Faecal samples from 120 infants collected at the ages of 5, 13 and 31 weeks were analysed and subjected to qPCR for the detection of several ARGs.

\section{Results:}

The prevalence of ARGs significantly increased for ermB, tetM and tetQ, while it decreased for $\operatorname{aac}\left(6^{\prime}\right)$-aph(2"). Birth-mode and breastfeeding duration significantly affected tetQ prevalence. Correlations to bacterial taxa suggest that fluctuations in some ARGs are (partly) attributed to shifts in bacteroides colonization rates.

\section{Conclusion:}

Acquisition of ARGs in the gut microbiota occurs shortly after birth and resistome composition fluctuates over the course of several months, reflecting changes in microbial community structure. 


\section{Introduction}

Antimicrobial resistance (AMR) is one of the major public health threats that we currently face worldwide. AMR limits clinical treatment options for bacterial infections and thereby reduces clinical efficacy and increases treatment costs and mortality. In the past decades, most research on AMR has been focused on resistance in clinically relevant pathogenic bacteria, greatly enhancing our understanding on the prevalence and distribution of the AMR in these pathogens. However, over the last couple of years, a growing interest has emerged for the entire collection of antibiotic resistance genes (ARGs) within microbial ecosystems; the resistome.

Bacterial communities such as the gut or soil microbiome are considered reservoirs of ARGs, where resistance in one bacterial species has the potential to spread to other, possibly pathogenic, bacteria as a result of horizontal gene transfer (HGT) $[1,2]$. Studies have in fact shown that human pathogens and environmental bacteria share similar resistance genes [2-4]. Moreover, several resistance genes that currently cause major problems in the clinical treatment, such as the $b / a_{\text {СTX-M }}$ or $b a_{\mathrm{OXA}-181}$ (a bla $a_{\mathrm{OXA}-48}$ derivative) genes, originate from environmental bacteria [5-7].

The human gut microbiome harbours numerous functional antibiotic resistance genes $[8,9]$, which have the potential to disseminate to other potentially harmful bacteria in the gut. Due to its high density of microorganisms, the indigenous microbiome is considered to be a highly accessible reservoir of antibiotic resistance [10], where HGT interactions may be frequent. Also, the gastrointestinal tract is constantly exposed to numerous bacteria from the environment, e.g., food, water, soil, other humans, or animals, which often harbour ARGs [11].

It has been shown that ARGs are present within the gut microbiota from early life and without any previous antibiotic exposure [12-14]. However, data on how the gut resistome develops and how it is influenced is limited. Colonization of the gut starts as soon as amniotic membranes rupture, and has even been suggested to already take place in utero [15]. Its composition fluctuates rapidly for several years and is influenced by many different factors, such as the mode of delivery, type of infant feeding, gestational age and antibiotic use by the infant [16]. Changes to the developing microbiota may also permanently alter its associated resistome. In order to gain better insight into the early development of the human 
gut resistome and the potential deterministic factors, the aim in this study was to assess the prevalence of several ARGs in the gut microbiome of infants, over the course of the first several months following birth.

\section{Materials \& Methods}

\section{Study population}

The present study was conducted within the context of a randomized, placebocontrolled trial on the primary prevention of atopic dermatitis by oral supplementation of a bacterial lysate in very early infancy (registration no. ISRCTN60475069). The study was approved by the Charite Ethics Committee in 2002, and informed consent was given by all parents. Exclusion criteria were antibiotic treatment or other medication before the first sampling point ( 5 weeks after birth), lymphocytopenia, thrombocytopenia or intensive care after birth. The design of this trial has been described in detail elsewhere [17].

In the present study, a random subset of 120 infants that were allocated to the placebo-group of that prospective cohort study was included. From week 5 until the end of week 31 postpartum, infants were orally supplemented with the placebo daily. Parents were asked to sample the infant's faeces at the age of 5 weeks (start of intervention), at 13 weeks, and at 31 weeks (end of intervention). Participants were provided with standard stool tubes with spoons attached to the lid (Sarstedt, Hilden, Germany) and instructed to collect the faecal sample before the next visit during which times samples were handed to the researchers.

\section{Stool processing and DNA extraction}

Processing and DNA extraction of the stool samples was performed as described previously [18]. Briefly, within 8 hours upon defecation, stool samples were 10 -fold diluted in Crowser-medium ( $5 \mathrm{~g}$ of Lab Lemco [meat extract $3.0 \mathrm{~g} / \mathrm{L}$ and Pepton $5 \mathrm{~g} / \mathrm{L}]+50 \mathrm{~mL}$ of Gycerol and $450 \mathrm{~mL}$ of $\mathrm{H} 2 \mathrm{O} ; \mathrm{pH} 7.3$ ) and then immediately stored at $-80^{\circ} \mathrm{C}$ until further analysis. For the extraction of metagenomic DNA, $200 \mu \mathrm{l}$ of diluted faeces was added to a $2-\mathrm{mL}$ vial containing approximately $0.3 \mathrm{~g}$ of $0.1 \mathrm{~mm}$ glass beads and $1.4 \mathrm{~mL}$ of ASL buffer from the QIAamp DNA stool minikit (Qiagen, Hilden, Germany). Samples were disrupted in a mechanical bead beater at $5000 \mathrm{rpm}$ for 3 minutes. Subsequently, the bacterial DNA was isolated from the samples with the QIAamp DNA stool mini kit, 
according to the instructions provided by the manufacturer. The DNA was eluted in a final volume of $200 \mu \mathrm{L}$ and stored at $-20^{\circ} \mathrm{C}$ until further analysis.

\section{Real time PCR assays}

Real-time PCR was performed to detect genes conferring resistance to different classes of antibiotics. Included were the $\beta$-lactamase encoding gene $c f \times A$, tetracycline resistance encoding genes tet $M$ and tet $Q$, macrolide resistance encoding gene $\mathrm{erm} B$, aminoglycoside resistance encoding gene $\operatorname{arc}\left(6^{\prime}\right)$-aph( (2") and quinolone resistance encoding gene qnrS. The $16 \mathrm{~S}$ ribosomal DNA (rDNA) was amplified as a reference gene to normalize for the amount of bacterial DNA in the samples. All targets except for qnrS were amplified on a $\mathrm{MyiQ}^{\text {TM }}$ Single-Color RealTime PCR Detection System (BioRad, Hercules, CA, USA) in $25 \mu$ l reactions containing $12.5 \mu \mathrm{l} \mathrm{iQ}^{\mathrm{TM}}$ SYBR $^{\circledR}$ Green Supermix (BioRad) and $5 \mu$ template DNA. The $q n r S$ gene was amplified on a 7900HT Fast Real-Time PCR System (Applied Biosystems) in $25 \mu$ l reactions containing $12.5 \mu$ l ABsolute QPCR ROX Mix (Thermo Scientific, Waltham, MA, USA) and $10 \mu \mathrm{l}$ template DNA. Primer sequences and concentrations, as well as cycling conditions and PCR efficiencies were as described earlier [19]. ARG abundance was calculated by transforming the CT value into an arbitrary unit copy number using the efficiency slope of the respective target.

\section{Statistical analysis}

The prevalence of a resistance gene was compared between the three different time points by using the McNemar's test for paired samples. Univariable logistic regression analysis were used to test for the association between birth mode, breastfeeding duration, number of siblings, time of introduction to solid foods, exposure to day-care centres or antibiotics used (as independent variables) and the presence of antibiotic resistance genes (as the dependent variable).

Data about the presence and abundance (counts in log10 Colony Forming Units) of the following key bacterial groups and species: Bacteroides fragilis group, bifidobacteria, Clostridium cluster I, Clostridium difficile, Escherichia coli and lactobacilli, were previously determined [18]. Chi square tests were performed to test for associations between colonization by these bacterial taxa and ARGs prevalence, when the colonization prevalence was between $25-75 \%$. Mann-Whitney $U$ tests were performed to determine associations of the 
abundance of bacterial taxa and the presence of ARGs. Pearson correlation was used to investigate the correlation between concentrations of gut bacteria and the abundance of ARGs. All analyses were performed using IBM SPSS Statistics version 20 and results were interpreted as statistically significant when $p<0.05$.

\section{Results}

\section{Study population}

Of the 120 infants included in this study, 61 (50.8\%) were girls and 59 (49.2\%) were boys. Twenty eight (23.3\%) infants were delivered by C-section, while 92 (76.7\%) were born vaginally. The majority of infants had no older siblings (65.8\%), while $25 \%$ and $9.2 \%$ had 1 or 2 older siblings respectively (see also Table S1). All but one of the infants were breastfed, with the duration ranging from 1 to 157 weeks (median of 42 weeks) and most infants (94.2\%) were introduced to solid foods before the last sampling time point (31 weeks). Eleven (9.2\%) infants had started day-care before 31 weeks, while the other had not. The number of oral antibiotic prescriptions were recorded and resulted in 17 prescriptions for 14 $(11.7 \%)$ of the infants.

\section{Prevalence of ARGs in the weeks following birth}

Overall, the prevalence of ARGs gradually increased over the three time points (Figure 1). While the prevalence of $c f x A$ showed a non-significant increasing trend, the ermB gene increased significantly from $25.0 \%$ to $55.0 \%$ ( $p<0.05)$. For tet $M$ and tet $Q$, the prevalence increased from $76.6 \%$ and $43.3 \%$ respectively at week 5 , to $92.5 \%(p<0.001)$ and $55.8 \%(p<0.05)$ at week 31 . Contrarily, a significant decrease was observed for the $\operatorname{aac}\left(6^{\prime}\right)$-aph(2") gene. Furthermore, anrS was detected in only 1 sample at both week 5 and 31, and was therefore not included in any statistical analysis. 


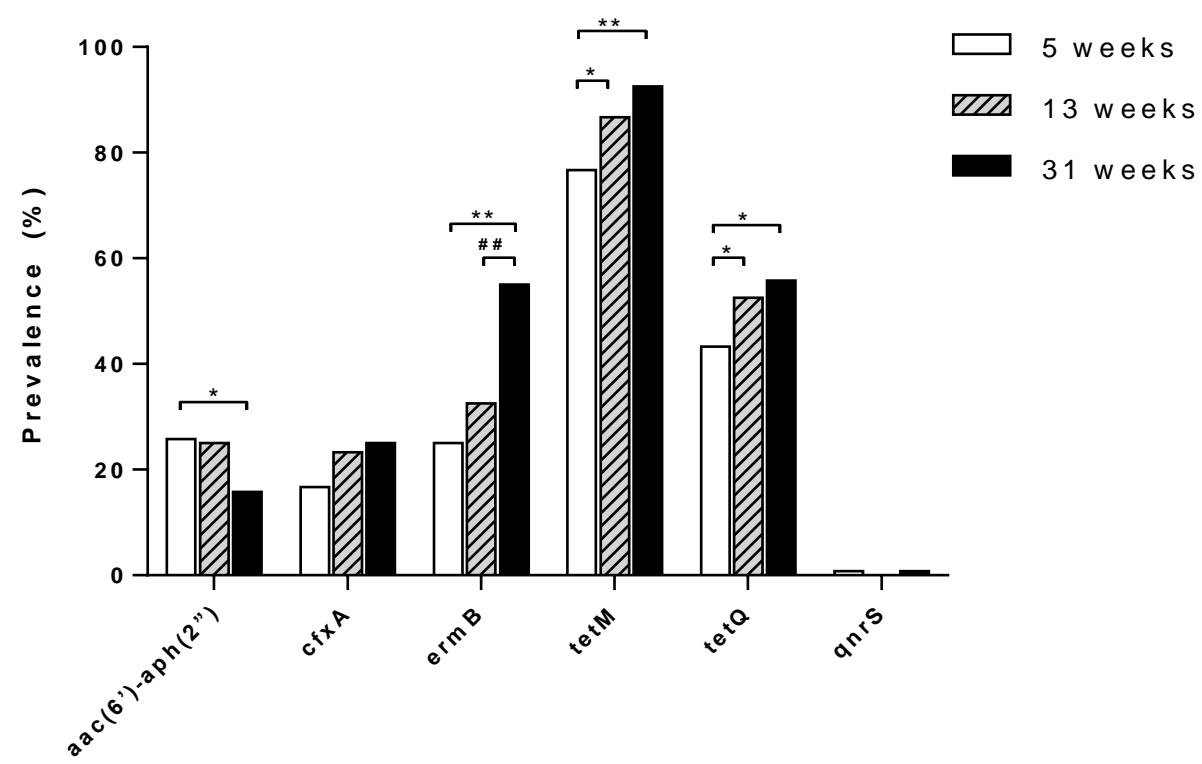

Figure 1. Prevalence of ARGs at three time points following birth. ${ }^{*} p<0.05$ compared to 5 weeks. ${ }^{* *} p<0.001$ compared to 5 weeks. \# $p<0.05$ compared to 13 weeks. \#\# $p<0.001$ compared to 13 weeks.

\section{Influence of population characteristics on ARG prevalence}

The impact of birth mode, duration of breastfeeding, introduction of solid foods, day-care, antibiotic use and the number of siblings on the prevalence of the ARGs were investigated and are shown in Table S1. Infants delivered by caesarean section showed a significantly lower prevalence of tetQ when compared to vaginally born infants at all three time points (Figure 2A, Table S1). The duration of breastfeeding also impacted the prevalence of the tetQ gene. At 31 weeks, infants breastfed for longer than 6 months showed a significantly lower prevalence of tetQ when compared to those breastfed for 0-6 months (Figure 2B, Table S1). Lastly, the number of older siblings showed an association with the prevalence of the cfxA gene at the age of 13 weeks, as the prevalence of this ARG increased from $16.5 \%$ for children with no siblings to $30.0 \%$ and $54.5 \%$ for children with 1 and 2 siblings respectively ( $p$ for trend $=0.005$ )

Prevalence rates of the investigated ARGs at 31 weeks were not associated with any antibiotic prescriptions or day-care attendance, although these factors suffered from a low sample size of the respective groups (Table S1). Neither was 
there a difference between the introduction of solid foods before or after 6 months of age. In this study, one dizygotic twin pair was included. In a sensitivity analysis it was, however, shown that excluding one of both infants did not influence our results.
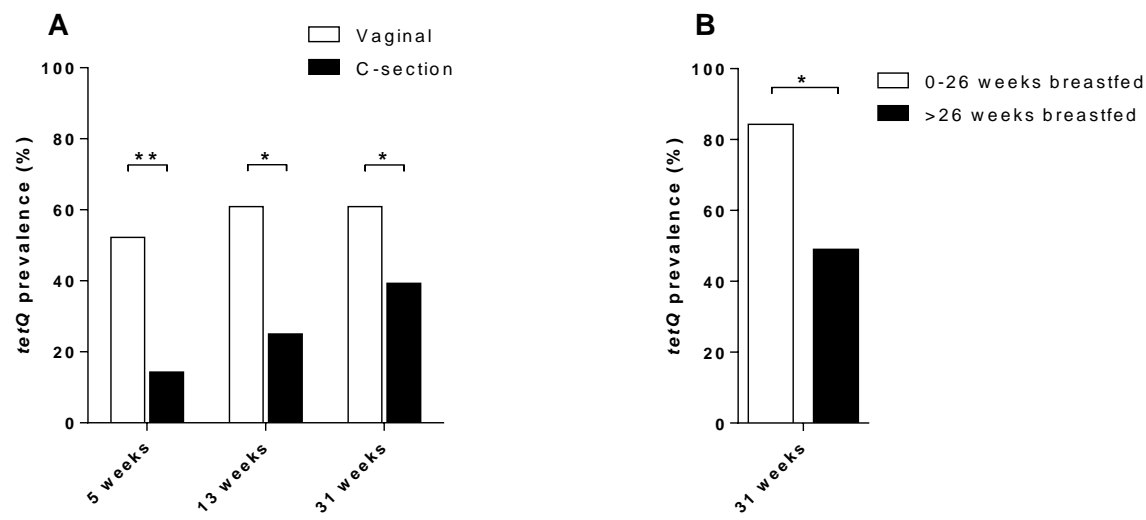

Figure 2. Correlation of ARGs with mode of delivery or breast feeding duration. (A) Prevalence of tetQ in the gut microbiome of infants delivered either vaginally (white bars) or by Cesarean (C)-section (black bars) at 5, 13 and 31 weeks postpartem. (B) Prevalence of tetQ in the gut microbiome of infants breastfed 0-26 weeks (white bars) or $>26$ weeks (black bars). ${ }^{*} \mathrm{p}<0.05 .{ }^{*} \mathrm{p}<0.001$.

\section{Correlation of ARGs to microbial composition}

The prevalence of all tested ARGs was compared to the previously determined microbial compositions of the faecal samples. Firstly, colonization prevalence with the B. fragilis group bacteria (from here on referred to as bacteroides), bifidobacteria, clostridium cluster I, Clostridium difficile, Escherichia coli and lactobacilli was compared with the prevalence of ARGs. A clear positive association was found between colonization with the bacteroides and the prevalence of the tet $Q$ gene (Figure $3 \mathrm{~A}$ ). The colonization with bacteroides was, to a somewhat lesser extent, also associated with the prevalence of $c f x A$ (Figure $3 B$ ), and with that of the ermB gene only at 31 weeks ( $p<0.05$, data not shown). Furthermore, the colonization with $C$. difficile was shown to be positively correlated with the prevalence of ermB and tetM only at 31 weeks (both $p<0.05$, data not shown). 

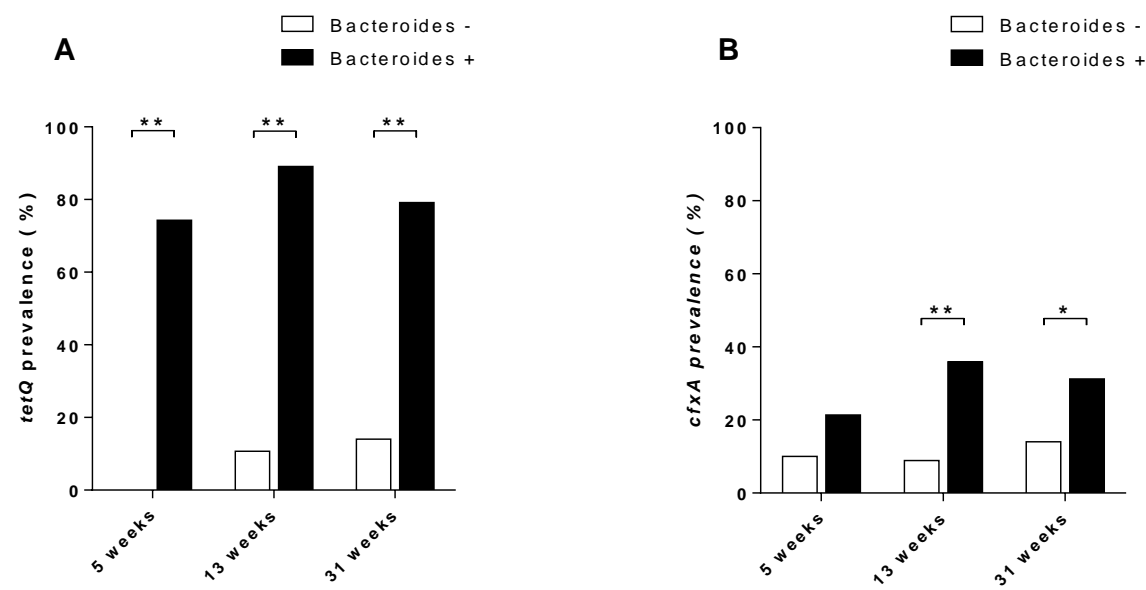

Figure 3. Correlation of ARGs to colonization with bacteroides. Prevalence of the $(A)$ tet $Q$ and (B) $c f x A$ genes in infant gut microbiota either uncolonized (white bars) or colonized (black bars) with bacteroides at 5, 13 and 31 weeks postpartum. ${ }^{*} p<0.05 .{ }^{* *} p<0.001$.

In order to more deeply define the observed correlations, the colonization abundance (log CFU per gram of faeces) of bacteroides and $C$. difficile positive samples was compared with the prevalence of their associated ARGs. For the bacteroides, a higher abundance correlated with the presence of tetQ at all three time points (all $p<0.05$, Figure S1A-C) and with $c f x A$ at 5 and 13 weeks (both $p<0.05$, Figure S1D-F). The abundance of $C$. difficile was neither associated with the prevalence of ermB nor with tetM. Finally, the colonization abundance of the bacteroides was also compared to the abundance (copy numbers) of the ARGs. Again, for the tet $Q$ gene, there was a correlation between these abundances for all three time points (all $p<0.001$, Figure $4 \mathrm{~A}-\mathrm{C}$ ). For $c f x A$, a correlation was found only at 31 weeks $(p<0.05$, Figure $4 D-F)$. 

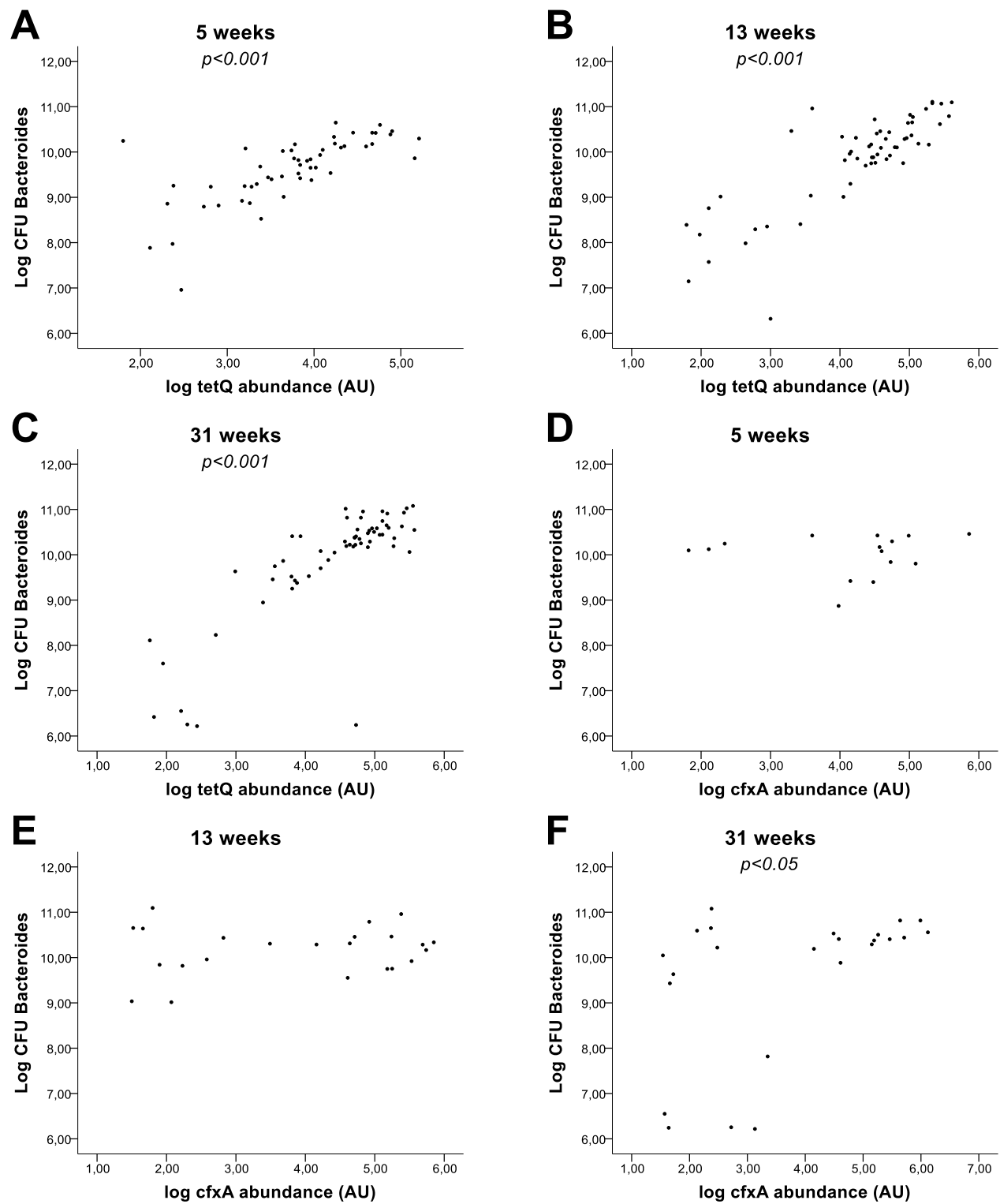

Figure 4. Correlation of bacteroides colonization rate to ARG abundance. Colonization rate of bacteroides in infant gut microbiota vs. the abundance of either tetQ $(A-C)$ or $c f x A$ $(D-F)$ at $5(A, D), 13(B, E)$, and 31 weeks postpartem (C, F). CFU, colony forming units; AU, arbitrary units. 


\section{Discussion}

In this study we demonstrate that the longitudinal development of the gut resistome starts already at a very early age and strongly reflects changes in the microbial community structure. Changes in the presence or amount of certain ARGs were correlated with changes in the microbial composition, which sheds light on the cause of several of our findings. For example, we found that infants who were delivered by caesarean section showed a significantly lower prevalence of tet $Q$ as compared to infants who were born vaginally. Previous studies have reported that the gut microbial composition of infants is affected by birth mode, Dominguez-Bello et al. showed that vaginal-delivered infants acquired bacterial communities resembling their own mothers' vaginal microbiota, whereas infants delivered by $\mathrm{C}$-section harboured bacterial communities that were most similar to those found on the skin surface [20]. Caesarean delivered infants are also believed to be exposed initially to bacteria originating from the hospital environment and health-care workers [21]. As a result, infants born via caesarean section are far less colonized with bacteroides $[16,18,22]$. The majority of clinical bacteroides harbour the tet $Q$ gene [23-25], which may explain the high correlation found in this study for the abundances of this gene and bacteroides. Over time, colonization rates with bacteroides for infants delivered via C-section seem to shift more towards the rates which are observed in vaginally delivered infants [18, 22], which is also well reflected in the diminishing difference between tetQ prevalence with increasing age for the two birth modes found in our study. Because of the difference in origin of the microbiota between vaginally and caesarean delivered infants, it would have been interesting to perform analysis for ARGs on the vaginal and faecal microbiota of the mothers of these infants as well. Unfortunately, such samples were not available for this study. Such an investigation was performed by Alicea-Serrano et al.; who reported that tet $Q$ was found in only 1 out of 8 of the maternal vaginal microbiota samples and none of the oral $(n=10)$ or faecal $(n=7)$ samples of either vaginally or C-section delivered neonates [26]. However, oral and faecal samples in that study were taken 15 minutes and 24 hours after birth respectively, which may be too short of a period for sufficient colonization to take place. Also, inclusion of the maternal faecal microbiota analysis would be of interest in future studies investigating this relation, since it is an important source of bacteroides and tet genes. In a recently performed study however, it was shown that the gut resistome of healthy infant 
twin siblings, in particularly with respect to $\beta$-lactam resistance genes, were significantly more similar to each other as compared to the resistome of their mother or unrelated infants [27].

Additionally, we found that infants who had been breastfed for longer than 6 months had a lower prevalence of tetQ. Several studies have shown that microbial composition is affected by breastfeeding [16, 28-30] and data of the microbial composition of our study population shows, amongst others, decreased amounts of bacteroides for infants who were breastfed for a longer time period [18]. Interestingly, while the prevalence of tet $Q$ in the infant microbiota increased from $43 \%$ at 5 weeks to $56 \%$ at 31 weeks, prevalence for this ARG in adult faecal samples was found to be $100 \%$ in a study we performed previously [19]. While there is little other metagenomic prevalence data about tet $Q$, this suggests that the prevalence of this gene in the gut microbiota will continue to follow a rising trend.

The $c f x A$ gene was also found to correlate with bacteroides colonization, but to a lesser degree, which is in line with studies that report a lower prevalence of $c f x A$ in these bacteria $[23,31]$ than is found for tetQ. Also, a dose-response relationship between the number of older siblings and the prevalence of the $c f x A$ gene was observed at 13 weeks of age. While the effect of birth order on the developing microbiota is not yet extensively recognized, some studies have indicated that older siblings influence the infants' microbiota [32, 33]. This effect was found to be especially pronounced in our study population, showing a higher amount of lactobacilli and bacteroides in the gut microbiota of infants with older siblings [18]. No correlation for tet $Q$ with the number of siblings was found however, suggesting that the $c f x A$ increase is also attributed to changes other than just those measured in the bacteroides.

A limitation of the current study is that the data presented are from infants born in the same geographical area (city of Berlin). While this area represents a multicultural community and great diversity concerning lifestyle and social economic status, the results may not allow for generalizability to other areas. Also, while the bacterial groups and species which were targeted by qPCR for microbiota analysis are considered to represent the major colonizers at this early age [34], and should thus cover major developments in the microbiota, this method does not provide a comprehensive analysis of the microbiota. Lastly, the investigated ARGs were previously shown to be present in different bacterial species [35-37] and have a varying prevalence in adult gut microbiota [19]. While 
these genes were monitored for their acquisition and as indicators of the flux in the paediatric resistome, they represent only a part of the immense resistome. Future studies should aim to include comprehensive analysis of the infant microbiome and resistome.

Taken together, our results show that the ARGs that we measured fluctuate according to and at least partially as a consequence of the fluctuation of the gut microbiota during the first few months after birth. These results may serve as an indication of how the human gut resistome at such an early age is shaped to a large degree by the composition of the gut microbiota. The direct clinical consequences of the presence of these ARGs in the microbiome at current and later age are not entirely clear. However, these genes have been described to confer e.g. aminoglycoside resistance in enterococci and staphylococci [35, 38], $\beta$ lactam resistance in Bacteroides and Prevotella [39], macrolide resistance in various species including enterococci, streptococci and Enterobacteriaceae [36, 40] or tetracycline resistance in many species including Bacteroides and Enterobacteriaceae [23-25, 37]. Colonization with resistant bacteria poses a risk for subsequent infections with those bacteria $[41,42]$ and moreover, these genes are often located on mobile genetic elements and their spread between various species in the human microbiota has been described [43, 44]. These results combined with evidence of genetic transfer of ARGs show that already at a young age, the microbiome presents a large reservoir of ARGs. In this regard, it would also be useful to monitor for lower prevalent but potentially more clinically relevant ARGs such as ESBL or carbapenemase genes, since the risks of increasing rates of these genes are easier to interpret and could help to instigate interventions. It is for example not well understood whether caesarean delivery is a risk for higher prevalence rates of drug resistant opportunistic pathogens originating from healthcare environments, or whether geographical differences in ARG prevalence affect the resistome at an early age. 


\section{Conclusion}

Our study provides insights into the presence and fluctuations of several ARGs in infantile gut microbiota throughout the first months after birth. For some ARGs we were able to associate changes in their presence and load with that of the bacteria they are normally harboured by. This included differences in microbiota which have been observed as a result of different modes of delivery, for example. In order to increase our understanding of the development of the human gut resistome, further studies on the infant gut resistome including both commensal as well as clinically relevant ARGs will be essential. 


\section{References}

1. Stokes HW, Gillings MR. Gene flow, mobile genetic elements and the recruitment of antibiotic resistance genes into Gram-negative pathogens. FEMS Microbiol Rev. 2011;35(5):790-819.

2. Stoll C, Sidhu JP, Tiehm A, Toze S. Prevalence of clinically relevant antibiotic resistance genes in surface water samples collected from Germany and Australia. Environ Sci Technol. 2012;46(17):9716-26.

3. Forsberg KJ, Reyes A, Wang B, Selleck EM, Sommer MO, Dantas G. The shared antibiotic resistome of soil bacteria and human pathogens. Science. 2012;337(6098):1107-11.

4. Spanogiannopoulos P, Waglechner N, Koteva K, Wright GD. A rifamycin inactivating phosphotransferase family shared by environmental and pathogenic bacteria. Proc Natl Acad Sci U S A. 2014;111(19):7102-7.

5. Poirel L, Kampfer P, Nordmann P. Chromosome-encoded Ambler class A betalactamase of Kluyvera georgiana, a probable progenitor of a subgroup of CTX-M extended-spectrum beta-lactamases. Antimicrob Agents Chemother. 2002;46(12):4038-40.

6. Poirel L, Rodriguez-Martinez JM, Mammeri H, Liard A, Nordmann P. Origin of plasmid-mediated quinolone resistance determinant QnrA. Antimicrob Agents Chemother. 2005;49(8):3523-5.

7. Potron A, Poirel L, Nordmann P. Origin of OXA-181, an emerging carbapenemhydrolyzing oxacillinase, as a chromosomal gene in Shewanella xiamenensis. Antimicrob Agents Chemother. 2011;55(9):4405-7.

8. Salyers AA, Gupta A, Wang Y. Human intestinal bacteria as reservoirs for antibiotic resistance genes. Trends Microbiol. 2004;12(9):412-6.

9. Sommer MO, Dantas G, Church GM. Functional characterization of the antibiotic resistance reservoir in the human microflora. Science. 2009;325(5944):1128-31.

10. Penders J, Stobberingh EE, Savelkoul PH, Wolffs PF. The human microbiome as a reservoir of antimicrobial resistance. Front Microbiol. 2013;4:87.

11. Baquero F. Metagenomic epidemiology: a public health need for the control of antimicrobial resistance. Clin Microbiol Infect. 2012;18 Suppl 4:67-73.

12. Zhang L, Kinkelaar D, Huang Y, Li Y, Li X, Wang HH. Acquired antibiotic resistance: are we born with it? Appl Environ Microbiol. 2011;77(20):7134-41.

13. Fouhy F, Ogilvie LA, Jones BV, Ross RP, Ryan AC, Dempsey EM, et al. Identification of aminoglycoside and beta-lactam resistance genes from within an infant gut functional metagenomic library. PLoS ONE. 2014;9(9):e108016.

14. Moore AM, Patel S, Forsberg KJ, Wang B, Bentley G, Razia Y, et al. Pediatric fecal microbiota harbor diverse and novel antibiotic resistance genes. PLoS ONE. 2013;8(11):e78822.

15. Funkhouser LJ, Bordenstein SR. Mom knows best: the universality of maternal microbial transmission. PLoS Biol. 2013;11(8):e1001631.

16. Penders J, Thijs C, Vink C, Stelma FF, Snijders B, Kummeling I, et al. Factors influencing the composition of the intestinal microbiota in early infancy. Pediatrics. 2006;118(2):511-21. 
17. Lau S, Gerhold K, Zimmermann K, Ockeloen CW, Rossberg S, Wagner P, et al. Oral application of bacterial lysate in infancy decreases the risk of atopic dermatitis in children with 1 atopic parent in a randomized, placebo-controlled trial. J Allergy Clin Immunol. 2012;129(4):1040-7.

18. Penders J, Gerhold K, Stobberingh EE, Thijs C, Zimmermann K, Lau S, et al. Establishment of the intestinal microbiota and its role for atopic dermatitis in early childhood. J Allergy Clin Immunol. 2013;132(3):601-7 e8.

19. von Wintersdorff CJ, Penders J, Stobberingh EE, Oude Lashof AM, Hoebe CJ, Savelkoul $\mathrm{PH}$, et al. High rates of antimicrobial drug resistance gene acquisition after international travel, The Netherlands. Emerg Infect Dis. 2014;20(4):649-57.

20. Dominguez-Bello MG, Costello EK, Contreras M, Magris M, Hidalgo G, Fierer N, et al. Delivery mode shapes the acquisition and structure of the initial microbiota across multiple body habitats in newborns. Proc Natl Acad Sci U S A. 2010;107(26):11971-5.

21. Wall R, Ross RP, Ryan CA, Hussey S, Murphy B, Fitzgerald GF, et al. Role of gut microbiota in early infant development. Clinical medicine Pediatrics. 2009;3:45-54.

22. Gronlund MM, Lehtonen OP, Eerola E, Kero P. Fecal microflora in healthy infants born by different methods of delivery: permanent changes in intestinal flora after cesarean delivery. J Pediatr Gastroenterol Nutr. 1999;28(1):19-25.

23. Eitel Z, Soki J, Urban E, Nagy E. The prevalence of antibiotic resistance genes in Bacteroides fragilis group strains isolated in different European countries. Anaerobe. 2013;21:43-9.

24. Tran CM, Tanaka K, Watanabe K. PCR-based detection of resistance genes in anaerobic bacteria isolated from intra-abdominal infections. Journal of infection and chemotherapy : official journal of the Japan Society of Chemotherapy. 2013;19(2):279-90.

25. Bartha NA, Soki J, Urban E, Nagy E. Investigation of the prevalence of tetQ, tetX and tetX1 genes in Bacteroides strains with elevated tigecycline minimum inhibitory concentrations. Int J Antimicrob Agents. 2011;38(6):522-5.

26. Alicea-Serrano AM, Contreras M, Magris M, Hidalgo G, Dominguez-Bello MG. Tetracycline resistance genes acquired at birth. Arch Microbiol. 2013;195(6):447-51.

27. Moore AM, Ahmadi S, Patel S, Gibson MK, Wang B, Ndao MI, et al. Gut resistome development in healthy twin pairs in the first year of life. Microbiome. 2015;3:27.

28. Hascoet JM, Hubert C, Rochat F, Legagneur H, Gaga S, Emady-Azar S, et al. Effect of formula composition on the development of infant gut microbiota. J Pediatr Gastroenterol Nutr. 2011;52(6):756-62.

29. Penders J, Vink C, Driessen C, London N, Thijs C, Stobberingh EE. Quantification of Bifidobacterium spp., Escherichia coli and Clostridium difficile in faecal samples of breast-fed and formula-fed infants by real-time PCR. FEMS Microbiol Lett. 2005;243(1):141-7.

30. Azad MB, Konya T, Maughan H, Guttman DS, Field CJ, Chari RS, et al. Gut microbiota of healthy Canadian infants: profiles by mode of delivery and infant diet at 4 months. CMAJ. 2013;185(5):385-94.

31. Soki J, Gonzalez SM, Urban E, Nagy E, Ayala JA. Molecular analysis of the effector mechanisms of cefoxitin resistance among Bacteroides strains. J Antimicrob Chemother. 2011;66(11):2492-500. 
32. Adlerberth I, Strachan DP, Matricardi PM, Ahrne S, Orfei L, Aberg N, et al. Gut microbiota and development of atopic eczema in 3 European birth cohorts. J Allergy Clin Immunol. 2007;120(2):343-50.

33. Yap GC, Chee KK, Hong PY, Lay C, Satria CD, Sumadiono, et al. Evaluation of stool microbiota signatures in two cohorts of Asian (Singapore and Indonesia) newborns at risk of atopy. BMC Microbiol. 2011;11:193.

34. Palmer C, Bik EM, DiGiulio DB, Relman DA, Brown PO. Development of the human infant intestinal microbiota. PLoS Biol. 2007;5(7):e177.

35. Boehr DD, Daigle DM, Wright GD. Domain-domain interactions in the aminoglycoside antibiotic resistance enzyme $\mathrm{AAC}\left(6^{\prime}\right)-\mathrm{APH}\left(2^{\prime \prime}\right)$. Biochemistry (Mosc). 2004;43(30):9846-55.

36. Kappell AD, DeNies MS, Ahuja NH, Ledeboer NA, Newton RJ, Hristova KR. Detection of multi-drug resistant Escherichia coli in the urban waterways of Milwaukee, WI. Front Microbiol. 2015;6:336.

37. Titilawo $\mathrm{Y}$, Obi L, Okoh A. Antimicrobial resistance determinants of Escherichia coli isolates recovered from some rivers in Osun State, South-Western Nigeria: Implications for public health. Sci Total Environ. 2015;523:82-94.

38. Daigle DM, Hughes DW, Wright GD. Prodigious substrate specificity of AAC $\left(6^{\prime}\right)$ $\mathrm{APH}\left(2^{\prime \prime)}\right.$, an aminoglycoside antibiotic resistance determinant in enterococci and staphylococci. Chem Biol. 1999;6(2):99-110.

39. Dupin C, Tamanai-Shacoori Z, Ehrmann E, Dupont A, Barloy-Hubler F, Bousarghin L, et al. Oral Gram-negative anaerobic bacilli as a reservoir of beta-lactam resistance genes facilitating infections with multiresistant bacteria. Int J Antimicrob Agents. 2015;45(2):99-105.

40. Jensen LB, Frimodt-Moller N, Aarestrup FM. Presence of erm gene classes in grampositive bacteria of animal and human origin in Denmark. FEMS Microbiol Lett. 1999;170(1):151-8.

41. Ben-Ami R, Schwaber MJ, Navon-Venezia S, Schwartz D, Giladi M, Chmelnitsky I, et al. Influx of extended-spectrum beta-lactamase-producing enterobacteriaceae into the hospital. Clin Infect Dis. 2006;42(7):925-34.

42. Vodovar D, Marcade G, Rousseau H, Raskine L, Vicaut E, Deye N, et al. Predictive factors for extended-spectrum beta-lactamase producing Enterobacteriaceae causing infection among intensive care unit patients with prior colonization. Infection. 2014;42(4):743-8.

43. Chung WO, Young K, Leng Z, Roberts MC. Mobile elements carrying ermF and tetQ genes in gram-positive and gram-negative bacteria. J Antimicrob Chemother. 1999;44(3):329-35.

44. Shoemaker NB, Vlamakis $H$, Hayes $K$, Salyers AA. Evidence for extensive resistance gene transfer among Bacteroides spp. and among Bacteroides and other genera in the human colon. Appl Environ Microbiol. 2001;67(2):561-8. 







\begin{tabular}{|c|c|c|c|c|c|c|c|c|}
\hline \multirow[t]{2}{*}{ 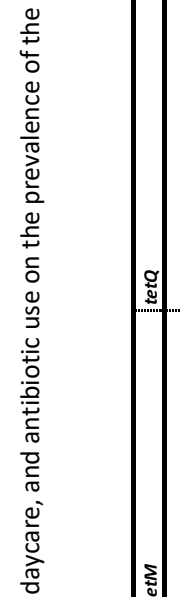 } & 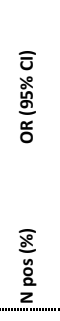 & 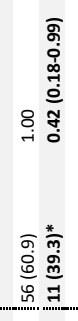 & 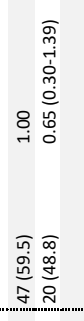 & 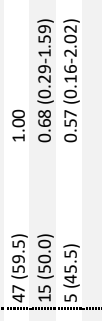 & 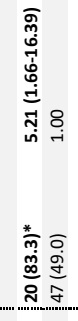 & 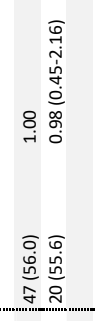 & 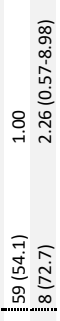 & 。 \\
\hline & $\begin{array}{l}\overline{\bar{\sigma}} \\
\stackrel{\circ}{\circ} \\
\text { o. } \\
\text { ó }\end{array}$ & 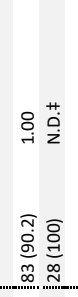 & 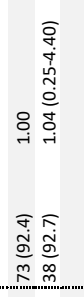 & 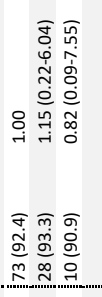 & 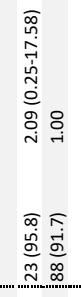 & 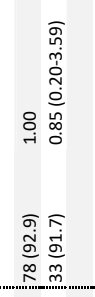 & 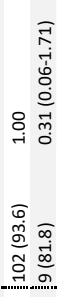 & $\begin{array}{l}\bar{n} \\
\stackrel{n}{\infty} \\
\infty\end{array}$ \\
\hline : & 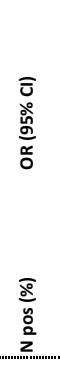 & 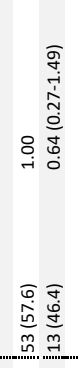 & 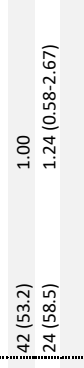 & 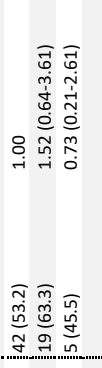 & 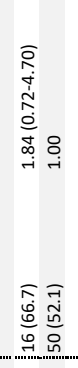 & 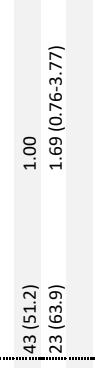 & 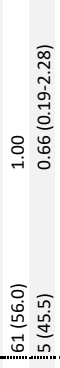 & \& \\
\hline 용 & 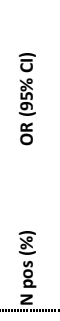 & 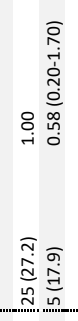 & 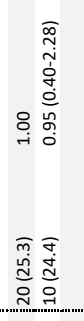 & 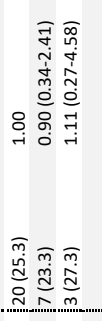 & 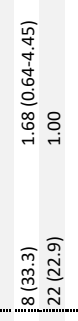 & 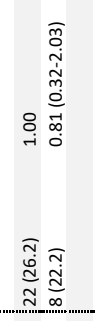 & 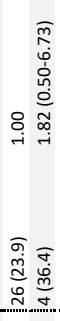 & \& \\
\hline 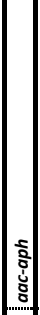 & $\begin{array}{l}\overline{\bar{a}} \\
\stackrel{\circ}{\circ} \\
\stackrel{\circ}{o} \\
\text { ó }\end{array}$ & 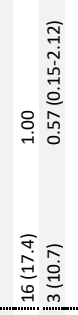 & 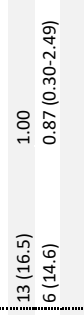 & 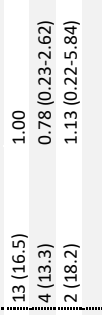 &  & 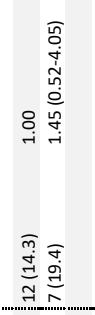 & 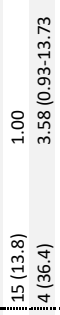 & 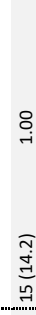 \\
\hline & $z \bar{\Phi}$ & 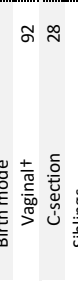 & 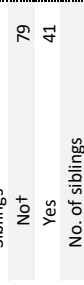 & 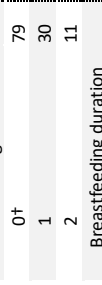 & 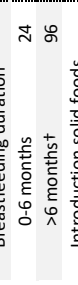 & 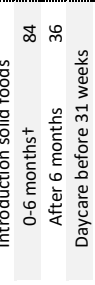 & 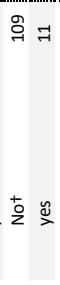 & $\stackrel{్}{ٍ}$ \\
\hline
\end{tabular}




\section{Supplemental Figure}
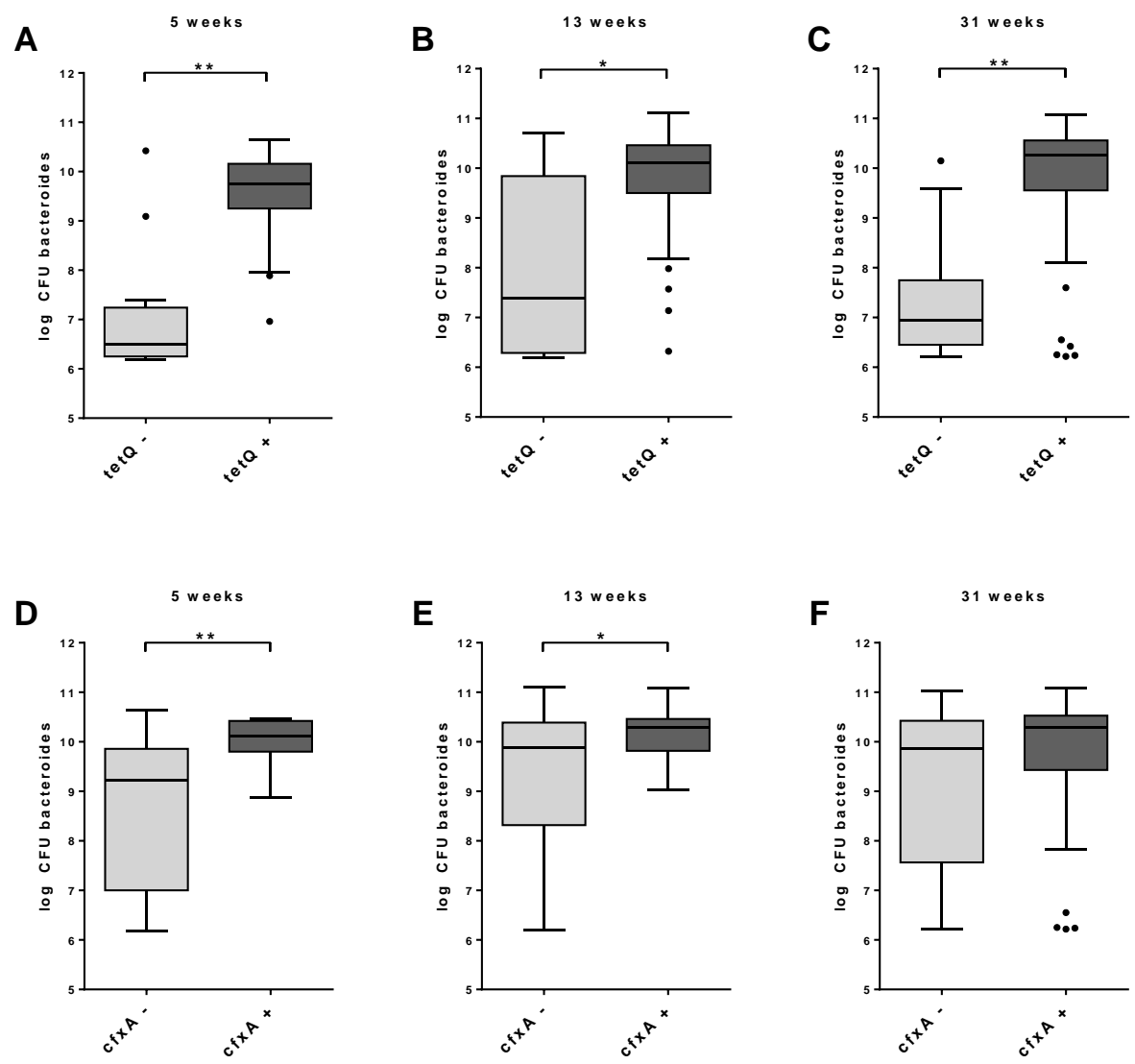

Figure S1. Correlation of bacteroides colonization rate to ARG presence. Colonization rate of bacteroides in infant gut microbiome negative $(-)$ or positive $(+)$ for either tetQ (AC) or $c f x A(D-F)$ at $5(A, D), 13(B, E)$ and 31 weeks postpartum $(C, F)$. Whiskers and outliers are displayed according to the Tukey method. ${ }^{*} p<0.05$. ${ }^{* *} p<0.001$. CFU, colony forming units. 


\section{Chapter 4A}

High rates of antimicrobial drug resistance gene acquisition after international travel, the Netherlands

Christian J.H. von Wintersdorff, John Penders, Ellen E. Stobberingh, Astrid M.L. Oude Lashof, Christian J.P.A. Hoebe, Paul H.M. Savelkoul \& Petra F.G. Wolffs

Emerg Infect Dis. 2014 Apr;20(4):649-57 


\begin{abstract}
We investigated the effect of international travel on the gut resistome of 122 healthy Dutch travellers by using a targeted metagenomic approach. Our results confirm high acquisition rates of the extended-spectrum beta-lactamase encoding gene $b l a_{\mathrm{CTX}-\mathrm{M}}$, as prevalence rose from $9.0 \%$ pre-travel to $33.6 \%$ post-travel $(p<0.001)$. Additionally, the prevalence of quinolone resistance encoding genes qnrB and qnrS rose from $6.6 \%$ and $8.2 \%$ pre-travel to $36.9 \%$ and $55.7 \%$ post-travel respectively (both $\mathrm{p}<0.001$ ). Travel to South-East Asia and the Indian subcontinent was associated with the highest acquisition rates of qnrS and both $b / a_{\mathrm{CTX}-\mathrm{M}}$ and qnrS respectively. Associations between the acquisitions of the bla $a_{\mathrm{CTX}-\mathrm{M}}$ and $q n r$ genes were investigated, but showed that the acquisition of a bla $a_{\text {CTX-M }}$ gene was not associated to that of a qnrB $(p=0.305)$ or qnrS gene $(p=0.080)$. These findings further support the increasing evidence that travellers are aiding in the spread of antimicrobial resistance.
\end{abstract}




\section{Introduction}

Antimicrobial resistance (AMR) is a public health threat worldwide, which continues to limit clinical treatment options for bacterial infections. The majority of research on AMR has been focused on resistance in clinically relevant pathogenic bacteria. However, there is a vast and largely unexplored reservoir of resistance genes present in non-pathogenic bacteria living in the environment or as commensals [1-5]. Because of horizontal gene transfer (HGT) between microbes of diverse species and genera, antibiotic resistance mechanisms in one organism, whether or not it is a pathogen, have the potential to emerge in clinically relevant pathogens [6]. Several of such HGT interactions between clinically relevant pathogens and environmental species have been described. For example, the plasmid-mediated quinolone resistance encoding qnrA gene was found to originate from the chromosomes of the aquatic bacterium Shewanella algae [7]. Another well-known example is the extended-spectrum beta-lactamase (ESBL) encoding bla $a_{\text {CTX-M }}$ gene, which originates from chromosomal genes of environmental Kluyvera species [8] and has now emerged as the most prevalent cause of plasmid-mediated ESBL.

With the unpredictable and immense potential of these resistance reservoirs in mind, the human gut microbiota warrants special attention, due to its high density of microorganisms and high accessibility [9]. The gastrointestinal tract is constantly exposed to numerous bacteria from the environment, via e.g. food, water, soil and other humans or animals. These incoming bacteria often harbour antibiotic resistance genes [10], which may be transferred to the indigenous microbial communities through HGT, enriching the pool of available AMR elements in the gut microbiota.

It is therefore important to conduct studies that focus on the AMR of the gut microbiome as a whole, the so-called 'gut resistome', by using cultureindependent metagenomic approaches [9]. These approaches avoid the bias that is introduced when selective culturing is applied, since approximately $80 \%$ of the gut microbiota is not cultivatable [11], and therefore allow for a more complete assessment of the resistome.

Traveling to geographic areas with high rates of bacterial antibiotic resistance has been indicated as a risk factor for the acquisition of antibiotic resistant bacteria [12]. Studies performed in Australia [13] Sweden[14, 15] and The Netherlands [16] have shown that international travel is indeed a major risk factor 
for colonization with ESBL-producing Enterobacteriaceae. Likely, these resistant strains are acquired from the environment during travel, e.g. through food consumption [17]. Since the human intestinal microbiome will come in contact with many different bacterial species from travel-related environments, the effect of international travel on AMR is most likely neither limited to opportunistic pathogens such as $E$. coli nor to ESBL-encoding resistance genes.

In this study, we aimed to investigate the effect of international travel on the human gut resistome. By using a targeted (PCR-based) metagenomic approach, we were able to compare the presence and relative abundance of specific resistance determinants in the entire human gut microbiome before and after international travel.

\section{Materials and Methods}

\section{Population and design}

Healthy long-distance travelers were recruited between November 2010 and August 2012 through travel clinics (EASE Travel Clinic \& Health Support) located in the southern part of The Netherlands. Travelers consenting to participate were asked to collect a stool sample prior to and immediately after travel, along with records of the duration and destination of their travel, illnesses or complaints during travel, drug use and antibiotic usage within the 3 months preceding travel. The stool samples were sent in via regular mail, the same day of collection, and were further processed on the day of receipt. A total of 122 travelers were included.

The countries visited were categorized into geographic regions: South-eastern (SE) Asia (Asia excluding the Indian subcontinent and the Middle-East), the Indian subcontinent (Bangladesh, Bhutan, India, Nepal, Pakistan and Sri Lanka), Northern Africa (countries north of the equator), Southern Africa (countries south of the equator), Southern Europe, Central America and South-America. 


\section{Stool processing and DNA extraction}

Stool samples were 10-fold diluted in peptone/water (Oxoid, Basingstoke, United Kingdom) containing 20\% (vol/vol) glycerol (Merck, Darmstadt, Germany), homogenized by vortexing and stored at $-20^{\circ} \mathrm{C}$ until molecular analysis.

For the extraction of metagenomic DNA, $200 \mu$ l of diluted feces was added to a 2-mL vial containing $0.5 \mathrm{~g}$ of $0.1 \mathrm{~mm}$ zirconia/silica beads (BioSpec, Bartlesville, OK, USA), 4 glass beads (3.0-3.5 mm)(BioSpec) and $1.2 \mathrm{ml}$ of lysis buffer from the PSP Spin Stool Kit (Stratec Molecular, Berlin, Germany). Samples were disrupted in a Magna Lyser device (Roche, Basel, Switzerland) in three cycles of 1 min. at a speed of $5500 \mathrm{rpm}$. Subsequently, metagenomic DNA was isolated from the samples with the PSP Spin Stool Kit, according to the manufacturer's instructions. DNA was eluted in $200 \mu$ lelution buffer and stored at $-20^{\circ} \mathrm{C}$ until further analysis.

\section{Real-time PCR assays}

Real-time PCR was performed to detect and quantify the $\beta$-lactamase encoding genes $c f X A, b / a_{\mathrm{CTX}-\mathrm{M}}$, and $b / a_{\mathrm{NDM}}$, tetracycline resistance encoding genes tet $M$ and tet $Q$, macrolide resistance encoding gene erm $B$, aminoglycoside resistance encoding gene $\operatorname{aac}\left(6^{\prime}\right)-a p h\left(2^{\prime \prime}\right)$ and quinolone resistance encoding genes qnrA, $q n r B$ and $q n r S$. The $16 \mathrm{~S}$ ribosomal DNA (rDNA) was amplified as a reference gene to normalize for the amount of bacterial DNA in the samples.

The $16 \mathrm{~S}$ rDNA, $c f x A$, tetM, tetQ, ermB and $\operatorname{aac}\left(6^{\prime}\right)$-aph(2") targets were amplified on a MyiQ $^{\text {TM }}$ Single-Color Real-Time PCR Detection System (BioRad, Hercules, CA, USA) in $25 \mu \mathrm{l}$ reactions containing $12.5 \mu \mathrm{l} \mathrm{iQ}^{\text {TM }}$ SYBR $^{\circledast}$ Green Supermix (BioRad) and $5 \mu$ template DNA. Melting curves were checked for each sample in order to confirm amplification of the correct product. For every target, amplified PCR products of 10 random positive samples were separated by agarose-gel electrophoresis to control for purity and size of the amplicons. Finally, for all genes except for the 16S rDNA (due to expected heterozygous amplicons), these products were sequenced using the PCR primers and an ABI BigDye Terminator v1.1 Cycle Sequencing Kit. Sequencing data were obtained on an $A B I$ 3730 DNA Analyzer (Applied Biosystems, Foster City, CA, USA) and were analyzed by using NCBI's Basic Local Alignment Search Tool (BLAST).

The $b l a_{\mathrm{CTX}-\mathrm{M}}, b / a_{\mathrm{NDM}}, q n r A, q n r B$ and $q n r S$ genes were amplified on a $7900 \mathrm{HT}$ Fast Real-Time PCR System (Applied Biosystems) in $25 \mu$ l reactions containing 12.5 $\mu l$ ABsolute QPCR ROX Mix (Thermo Scientific, Waltham, MA, USA) and $10 \mu \mathrm{l}$ template DNA. The $b / a_{\text {CTX-M }}$ assay allows for the identification of the various 
phylogenetic groups by the use of four probes. The probes to detect bla $a_{\mathrm{CTX}-\mathrm{M}}$ groups 1 and 2 were combined in one reaction, while the probe to detect $b / a_{\mathrm{CTX}-\mathrm{M}}$ group 9, and a probe to detect all groups except for the CTX-M-1 group were combined in a second reaction. All primer and probe sequences, as well as PCR conditions for each target are displayed in Table 1.

To determine the efficiency of the PCR assays, threshold cycle (Ct) values obtained from a series of 5 template DNA dilutions, of at least 3 different samples, were graphed on the $\mathrm{Y}$ axis versus the log of the dilution on the $\mathrm{X}$ axis. For $b / a_{\mathrm{NDM}}$ a clinical isolate was used since no positive stool samples were available. The PCR efficiencies were; 16S rDNA: 94.0\%, cfxA: 99.0\%, tetM: 97.6\%, tetQ: 95.9\%, ermB: 95.5\%, $\operatorname{aac}\left(6^{\prime}\right)-\operatorname{aph}\left(2^{\prime \prime}\right): 97.0 \%$, bla $_{\mathrm{CTX}-\mathrm{M}-1+2}: 98.2 \%$, bla $_{\mathrm{CTX}-\mathrm{M}-9+2-8-9-25}: 96.7 \%, b l a_{\mathrm{NDM}}$ : 98.4\%, qnrA: $97.4 \%$, qnrB: $101.0 \%$ and $q n r S: 102.5 \%$.

PCR Detection limits were determined for $b / a_{\text {CTX-M, }} q n r B$ and qnrS. Clinical isolates harboring these genes were suspended to a 0.5 McFarland solution, followed by 10 -fold dilutions in sterile saline solution. Quantification of colony forming units (CFU) in the suspensions was achieved by inoculating blood agar plates (Oxoid, Germany) and counting the number of colonies after overnight incubation at $37^{\circ} \mathrm{C}$. Next, $20 \mu \mathrm{l}$ of the quantified suspensions were mixed with 180 $\mu \mathrm{l}$ of stool sample and submitted to DNA extraction as described above. Subsequently qPCR was performed on extracted DNA to generate standard curves for quantification. For $b / a_{\mathrm{CTX}-\mathrm{M}}$, the detection limit was 12 to $40 \mathrm{CFU} / \mathrm{PCR}$ reaction. For both qnrB and qnrS the detection limit was 1 to 5 CFU/PCR reaction. 


\section{Statistics}

Differences in relative resistance gene abundances between pre-travel and post-travel samples were calculated for each traveler using the $\Delta \Delta \mathrm{Ct}$ method with

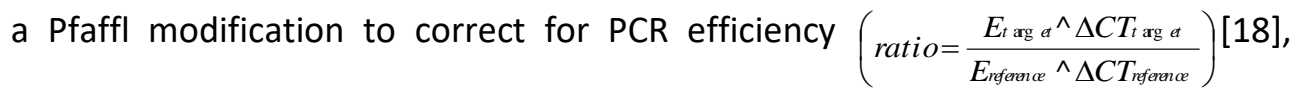
which is the standard method to measure the relative change in mRNA expression levels with real-time PCR. In this study however, rather than measuring mRNA expression levels; the relative amount of target DNA present was measured using this method. The $16 \mathrm{~S}$ rDNA was used as the reference gene.

For a better visualization of increases and decreases in gene abundances in graphs, abundance ratios were converted to a fold-change. To determine the overall abundance change of a resistance gene, ratios were log-transformed. A two-tailed one-sample t-test was used to test whether the mean log-ratio significantly differed from zero.

The number of stool samples positive for a resistance gene post-travel was compared to the positive samples which were present pre-travel, by using the McNemar's test for paired samples. Multivariable logistic regression analysis were used to test for the association between age, sex, travel destination and duration, traveler's diarrhea and antibiotic use preceding travel (as independent variables) and the acquisition of antibiotic resistance genes (as the dependent variable). The association between acquisitions of multiple resistance genes was determined by a chi-squared test.

All analyses were performed using IBM SPSS Statistics version 20 and results were interpreted as statistically significant when $p<0.05$. 


\section{Chapter 4A}

Table 1. PCR primer/probe sequences and additional PCR conditions to identify antimicrobial resistance genes in gut microbiota after international travel

\begin{tabular}{|c|c|c|c|c|c|}
\hline Primer/probe & $\begin{array}{l}\text { Sequence* } \\
5^{\prime}-3^{\prime}\end{array}$ & $\begin{array}{l}\text { Final } \\
\text { conc. } \\
\text { (nM) }\end{array}$ & $\begin{array}{l}\text { Prod. } \\
\text { size } \\
\text { (bp) }\end{array}$ & Cycling conditions & Ref. \\
\hline 16S-rDNA_F & TGGAGAGTTTGATCCTGGCTCAG & 500 & 526 & $95^{\circ} \mathrm{C}, 4 \mathrm{~m}$ & [19] \\
\hline 16S-rDNA_R & TACCGCGGCTGCTGGCAC & 250 & & $35 \times 95^{\circ} \mathrm{C}, 15 \mathrm{~s} ; 65^{\circ} \mathrm{C}, 60 \mathrm{~s}$ & \\
\hline cfxA_F & TGACAGTGAGAGATTTGCTGC & 300 & 150 & $95^{\circ} \mathrm{C}, 3 \mathrm{~m}$ & {$[20]$} \\
\hline$c f x A \_R$ & GGTCAGCCGACATTTCCTCTT & 300 & & $40 \times 95^{\circ} \mathrm{C}, 15 \mathrm{~s} ; 60^{\circ} \mathrm{C}, 15 \mathrm{~s} ; 72^{\circ} \mathrm{C}, 30 \mathrm{~s}$ & \\
\hline tetM_F & ACACGCCAGGACATATGGAT & 300 & 126 & $95^{\circ} \mathrm{C}, 3 \mathrm{~m}$ & [20] \\
\hline tetM_R & GGGAATCCCCATTTTCCTAA & 300 & & $40 \times 95^{\circ} \mathrm{C}, 15 \mathrm{~s} ; 57^{\circ} \mathrm{C}, 15 \mathrm{~s} ; 72^{\circ} \mathrm{C}, 30 \mathrm{~s}$ & \\
\hline tetQ_F & CAAGGTGATATCCGCTCTGA & 300 & 128 & $95^{\circ} \mathrm{C}, 3 \mathrm{~m}$ & [20] \\
\hline tetQ_R & GGAAAATCGTTCTTCCAGCA & 300 & & $40 \times 95^{\circ} \mathrm{C}, 15 \mathrm{~s} ; 57^{\circ} \mathrm{C}, 15 \mathrm{~s} ; 72^{\circ} \mathrm{C}, 30 \mathrm{~s}$ & \\
\hline ermB_F & AAGGGCATTTAACGACGAAACTG & 300 & 438 & $95^{\circ} \mathrm{C}, 3 \mathrm{~m}$ & This \\
\hline ermB_R & ATTTATCTGGAACATCTGTGGTATG & 300 & & $40 \times 95^{\circ} \mathrm{C}, 20 \mathrm{~s} ; 60^{\circ} \mathrm{C}, 30 \mathrm{~s} ; 72^{\circ} \mathrm{C}, 40 \mathrm{~s}$ & study \\
\hline aac6-aph2_F & TTGGGAAGATGAAGTTTTTAGA & 300 & 173 & $95^{\circ} \mathrm{C}, 3 \mathrm{~m}$ & [21] \\
\hline aac6-aph2_R & СCTTTACTCCAATAATTTGGCT & 300 & & $40 \times 95^{\circ} \mathrm{C}, 15 \mathrm{~s} ; 57^{\circ} \mathrm{C}, 20 \mathrm{~s} ; 72^{\circ} \mathrm{C}, 30 \mathrm{~s}$ & \\
\hline CTX-M_F & ATGTGCAGYACCAGTAARGTKATGGC & 500 & 336 & $95^{\circ} \mathrm{C}, 15 \mathrm{~m}$ & [22] \\
\hline CTX-M_R & ATCACKCGGRTCGCCNGGRAT & 500 & & $40 \times 95^{\circ} \mathrm{C}, 15 \mathrm{~s} ; 58^{\circ} \mathrm{C}, 20 \mathrm{~s}$ & \\
\hline CTX-M-1 & JOE-CCCGACAGCTGGGAGACGAAACGT-BHQ1 & 100 & & $72^{\circ} \mathrm{C}, 30 \mathrm{~s}$ & \\
\hline CTX-M-2 & 6FAM-CAGGTGCTTATCGCTCTCGCTCTGTT-BHQ1 & 100 & & & \\
\hline CTX-M-9 & JOE-CTGGATCGCACTGAACCTACGCTGA-BHQ1 & 100 & & & \\
\hline CTX-M-2-8-9-25 & 6FAM-CGACAATACYGCCATGAA-MGB-NFQ & 100 & & & \\
\hline NDM_F & ATTAGCCGCTGCATTGAT & 400 & 154 & $95^{\circ} \mathrm{C}, 15 \mathrm{~m}$ & [23] \\
\hline NDM_R & CATGTCGAGATAGGAAGTG & 400 & & $42 \times 95^{\circ} \mathrm{C}, 15 \mathrm{~s} ; 60^{\circ} \mathrm{C}, 60 \mathrm{~s}$ & \\
\hline NDM_probe & 6FAM- CTG[+C]CA[+G]AC[+A]TT[+C]GGTGC-BHQ1 & 200 & & & \\
\hline qnrA_F & CAGTTTCGAGGATTGCAGTT & 400 & 148 & $95^{\circ} \mathrm{C}, 15 \mathrm{~m}$ & [24] \\
\hline qnrA_R & CCTGAACTCTATGCCAAAGC & 400 & & $45 \times 95^{\circ} \mathrm{C}, 30 \mathrm{~s} ; 52^{\circ} \mathrm{C}, 30 \mathrm{~s}$ & \\
\hline qurA_probe & 6FAM-AAGGGTGYCACTTCAGCTATGCC-BHQ1 & 100 & & $72^{\circ} \mathrm{C}, 30 \mathrm{~s}$ & \\
\hline qnrB_F & CAGATTTYCGCGGCGCAAG & 400 & 134 & $95^{\circ} \mathrm{C}, 15 \mathrm{~m}$ & {$[24]$} \\
\hline qnrB_R & TTCCCACAGCTCRCAYTTTTC & 400 & & $45 \times 95^{\circ} \mathrm{C}, 30 \mathrm{~s} ; 55^{\circ} \mathrm{C}, 30 \mathrm{~s}$ & \\
\hline qnrB_probe & $\begin{array}{l}\text { 6FAM-CGCACCTGGTTTTGYAGYGCMTATATCAC- } \\
\text { BHQ1 }\end{array}$ & 100 & & $72^{\circ} \mathrm{C}, 30 \mathrm{~s}$ & \\
\hline qnrS_F & TCAAGTGAGTAATCGTATGTA & 400 & 157 & $95^{\circ} \mathrm{C}, 15 \mathrm{~m}$ & [24] \\
\hline qnrS_R & GTCTGACTCTTTCAGTGAT & 400 & & $45 \times 95^{\circ} \mathrm{C}, 30 \mathrm{~s} ; 55^{\circ} \mathrm{C}, 30 \mathrm{~s}$ & \\
\hline qnrS_probe & 6FAM-CCAGCGATTTTTCAAACAACTCAC-BHQ1 & 100 & & $72^{\circ} \mathrm{C}, 30 \mathrm{~s}$ & \\
\hline
\end{tabular}

*Nucleic acids between brackets and preceded by ' + ' are locked nucleic acids; nM, nanomolar; conc., concentration; Prod., product; bp, base pairs; Ref., reference. 


\section{Results}

\section{Study population}

A total of 122 travelers ( 71 women and 51 men) with a median age of 43 years (range, 18 to 72 years) were included. The median length of stay abroad was 21 days (range, 5 to 240 days). Fourteen participants traveled for over 60 days, 5 of these exceeded a travel length of 120 days. Most participants visited one country, while 22 visited more than one country. Six participants visited more than one of the defined geographic regions (table 2) and 7 participants did not provide information concerning their destination.

Table 2. Characteristics of the 122 travelers from the Netherlands

\begin{tabular}{|c|c|c|c|}
\hline & & Median & Range \\
\hline \multicolumn{2}{|c|}{ Age (years) } & 42.7 & $18-72$ \\
\hline \multirow{2}{*}{\multicolumn{2}{|c|}{ Travel duration (days) }} & 21.0 & $5-240$ \\
\hline & & No. & $\%$ \\
\hline \multirow[t]{2}{*}{ Sex: } & Female & 71 & 58.2 \\
\hline & Male & 51 & 41.8 \\
\hline \multicolumn{2}{|c|}{ Traveler's diarrhea } & 45 & 36.9 \\
\hline \multicolumn{2}{|c|}{ Antibiotic usage } & 15 & 12.3 \\
\hline \multicolumn{4}{|c|}{ Region visited: } \\
\hline & South-East Asia & 28 & 23.0 \\
\hline & Indian subcontinent & 31 & 25.4 \\
\hline & Northern Africa & 16 & 13.1 \\
\hline & Southern Africa & 17 & 13.9 \\
\hline & Southern Europe & 6 & 4.9 \\
\hline & Central America & 4 & 3.3 \\
\hline & South America & 6 & 4.9 \\
\hline & Other/multiple & 7 & 5.7 \\
\hline
\end{tabular}

The countries included in respective regions are: SE Asia (Indonesia, Philippines, Malaysia, Myanmar, Cambodia, Thailand, Vietnam), Indian subcontinent (India, Nepal, Sri Lanka), Northern Africa (Canary Islands, Egypt, Gambia, Ghana, Togo, Morocco, Senegal, Uganda), Southern Africa (Namibia, Kenya, Tanzania, Zanzibar, Mauritius, South-Africa), Central America (Panama, Costa Rica, Mexico) southern America (Argentine, Bolivia, Brazil, Columbia, Peru, Suriname), Southern Europe (Croatia, Spain, Turkey), Other (Australia, Fiji, New Zealand, Oman). 


\section{Prevalence of resistance genes in stool samples}

Figure 1 presents the prevalence of the antimicrobial resistance determinants in stool samples from healthy volunteers $(\mathrm{N}=122)$ before and after international travel. The cfxA gene was detected in 111 pre-travel stool samples (91.0\%) and in 115 post-travel samples (94.3\%). The extended spectrum beta-lactamase (ESBL) encoding bla $a_{\text {CTX-M }}$ gene was prevalent in 11 pre-travel samples $(9.0 \%)$, whereas the gene was detected in 41 samples after travel (33.6\%), which was a statistically significant increase $(p<0.001)$. Additionally, the post-travel samples of 5 individuals contained bla $a_{\text {CTX-M }}$ genes of two different phylogenetic groups, whereas pre-travel only a single CTX-M variant was detected for 2 of these individuals and $b / a_{\text {СтX-M }}$ was undetected for the other 3 individuals. For 6 individuals who were positive for the $b / a_{\text {CTX-M }}$ gene pre-travel, the gene was not detected in the post-travel sample. The carbapenemase encoding gene $b / a_{\mathrm{NDM}}$ was not detected in any sample.

The prevalence of both tet $M$ and tet $Q$ was found to be very high in the stool samples. The tet $M$ gene was present in all pre-travel samples and all except for one post-travel sample (99.2\%), while tet $Q$ was detected in every sample. The erm $B$ gene was also found to have a high prevalence in both pre- and post-travel samples (both 99.2\%). The prevalence of the $\operatorname{aac}\left(6^{\prime}\right)$-aph(2") gene was not altered by traveling; this gene was present in 79 pre-travel $(64.5 \%)$ and 86 post-travel samples (70.5\%).

The quinolone resistance genes qnrA, qnrB and qnrS all had a relatively low prevalence of $0.8 \%, 6.6 \%$ and $8.2 \%$ respectively in the pre-travel samples. In the post-travel samples however, increases for all three genes were observed, as qnrA, qnrB and qnrS were detected in $3.3 \%, 36.9 \%$ and $55.7 \%$ of the samples respectively. For $q n r B$ and $q n r S$, this was found to be significantly higher than pretravel (both $p<0.001$ ). 


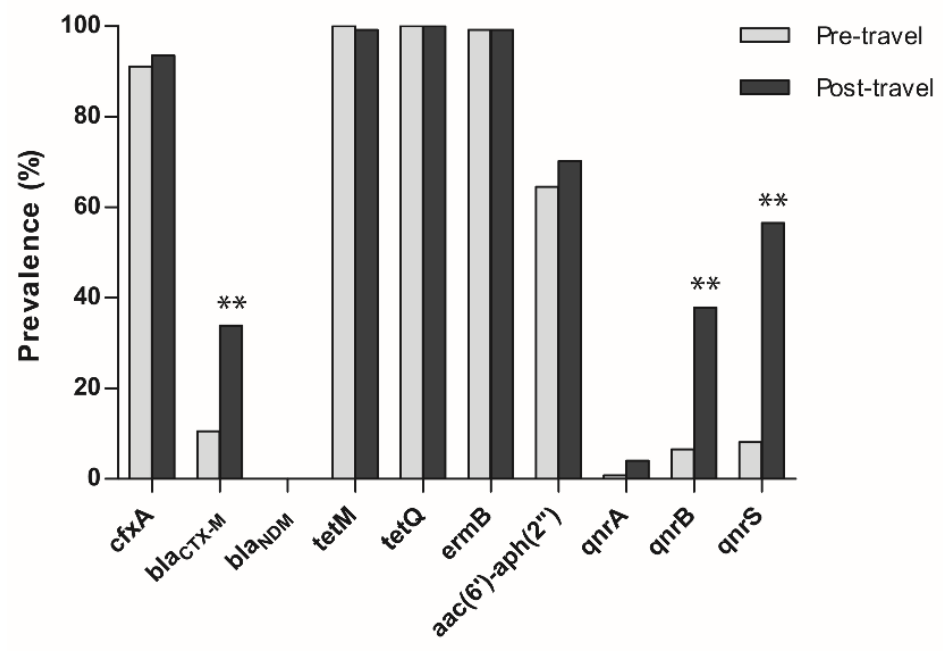

Figure 1. Prevalence (\%) of antibiotic resistance determinants in stool samples from healthy Dutch travelers $(\mathrm{N}=122)$ pre- and post-travel. Statistical significance of the prevalence between the two groups was calculated using the McNemar's test for paired samples and is denoted in the graph with ** $(p<0.001)$.

\section{Relative gene abundances before and after travel}

Since the prevalence of the $c f x A$, tetM, tet $Q$ and ermB genes were found to be very high in both pre-travel as well as post-travel samples; we compared the relative abundances of the genes between these samples for each traveler, in order to determine whether traveling influenced the gene abundance.

For all four genes, the observed changes in gene abundance per traveler were distributed between both increases and decreases (Figure 2). Determining the overall increase or decrease of the abundance of each gene showed that none of the investigated genes was significantly changed in abundance after travel, neither per continent nor in total. 
A

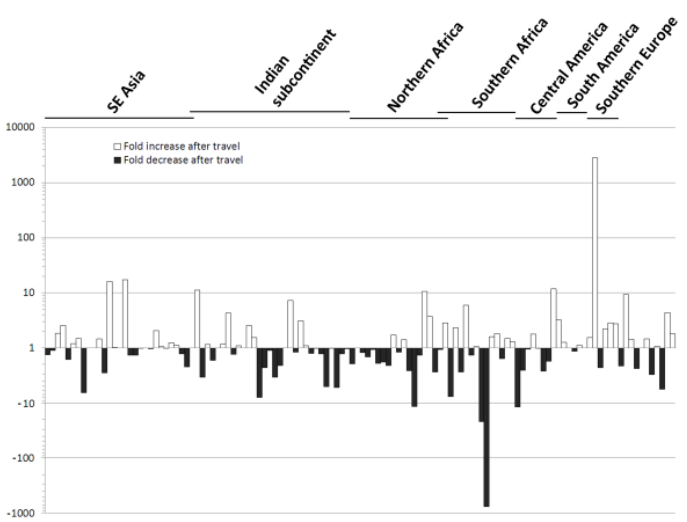

C

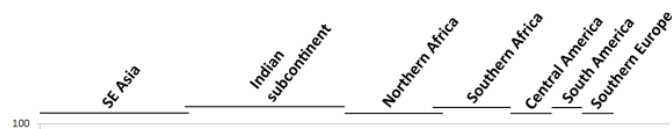

ㅁold increase after travel

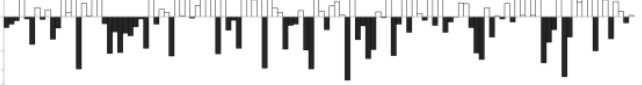

B



D

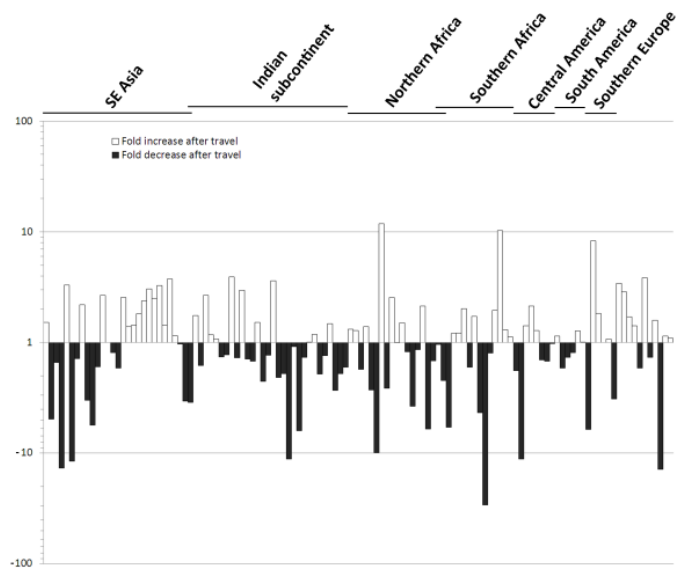

Figure 2. Relative fold changes in gene abundance post-travel compared to pre-travel for each of the 122 healthy Dutch travelers for genes $\operatorname{cfxA}(\mathrm{A})$, tetM (B), tetQ (C) and ermB (D). Increases are shown in white bars on the positive $Y$-axis, while decreases are shown in dark grey bars on the negative $\mathrm{Y}$-axis. Each bar on the $\mathrm{X}$-axis represents the change in a different volunteer. The travel destination regions of the volunteers are denoted above the graph. No region is indicated for some travelers who visited multiple of these regions or countries which did not classify in the displayed regions (see table 2 ). 


\section{Association of travel destination and other risk factors on gene acquisition}

The rate of acquisition of a $b / a_{\text {CTX-M }}$ gene was highest for travelers visiting the Indian subcontinent (58.1\%; $p<0.05$, OR 26.22, 95\%Cl 2.86-240.38) (Table 3). Travel to other regions was associated with a bla $a_{\text {CTX-M }}$ acquisition rate of $17.9 \%$ for SE Asia, 31.3\% and $29.4 \%$ for Northern and Southern Africa respectively. In the combined Europe \& America category, only $1 b l a_{\text {CTX-M }}$ acquisition was observed $(6.3 \%)$, which was detected in a traveler who had been to Southern Europe (Turkey).

The acquisition of the qnrB gene was not statistically significantly associated with travel to a specific region, whereas the acquisition of qnrS was highest for SE Asia (75.0\%; $p=0.001$, OR 15.74, 95\% Cl 3.13-79.24), followed by the Indian subcontinent (61.3\%; $\mathrm{p}<0.05$, OR 9.23, 95\% $\mathrm{Cl}$ 1.94-43.87). The acquisition rate was also elevated for Northern Africa (43.8\%) and Southern Africa (35.3\%), but was not significant.

Furthermore, associations between age, sex, travel destination and duration, traveler's diarrhea and antibiotic use preceding travel and the acquisition of resistance genes were investigated, but none were found (Table 3).

\section{Phylogenetic groups of $\mathbf{b l a} \boldsymbol{a}_{\mathrm{CTX}-\mathrm{M}}$ genes and association with qnr genes}

Of the total of $41 b / a_{\text {CTX-M }}$ genes acquired during travel, 24 belonged to the CTX-M-1 group, 2 belonged to the CTX-M-2 group, 6 were of the CTX-M- 9 group and 9 were positive for the CTX-M-2-8-9-25-probe, but not for the CTX-M-2 or 9 probe, indicating that these were groups 8 or 25 . The CTX-M groups acquired per region are shown in table 4 . In contrast, 9/11 CTX-M types detected in the pretravel samples belonged to the CTX-M-9 group and only $2 / 11$ to the CTX-M-1 group.

Associations between the acquisitions of the $b / a_{\mathrm{CTX}-\mathrm{M}}$ and $q n r$ genes were investigated as well (table 5), but showed that the acquisition of a $b / a_{\text {CTX-M }}$ gene was not associated to that of a qnrB $(p=0.305)$ or qnrs gene $(p=0.080)$. Neither was the gain of a bla $a_{\mathrm{CTX}-\mathrm{M}}$ gene of the CTX-M-1 group, which was the dominant acquired type (58.5\%), associated with the acquisition of either $q n r B(p=0.631)$ or qnrS $(p=0.256)$. 
Table 3. Associations between (travel-associated) risk factors and acquisition rates of blaCTX-M, qnrB and qnrS among 122 healthy Dutch travelers

\begin{tabular}{|c|c|c|c|c|c|c|c|}
\hline & \multirow{2}{*}{$\begin{array}{l}\text { No. } \\
\text { travelers }\end{array}$} & \multicolumn{2}{|c|}{$b / a_{\text {СTX-M }}$} & \multicolumn{2}{|c|}{$\begin{array}{l}\text { Travelers with gene acquisition } \\
\qquad q n r B \\
\end{array}$} & \multicolumn{2}{|c|}{ qnrS } \\
\hline & & No. (\%) & $\mathrm{OR}(95 \% \mathrm{Cl})+$ & No. (\%) & $\mathrm{OR}(95 \% \mathrm{Cl})+$ & No. (\%) & $\mathrm{OR}(95 \% \mathrm{Cl}){ }^{\dagger}$ \\
\hline Region visited & & & & & & & \\
\hline $\begin{array}{l}\text { Europe \& } \\
\text { America § }\end{array}$ & $16^{*}$ & $1(6.3)$ & 1.00 & $6(37.5)$ & 1.00 & $3(18.8)$ & 1.00 \\
\hline SE Asia & $28^{*}$ & 5 (17.9) & $\begin{array}{l}3.34 \\
(0.34-33.14)\end{array}$ & $7(25.0)$ & $\begin{array}{l}0.47 \\
(0.12-1.90)\end{array}$ & $21(75.0)$ & $\begin{array}{l}15.74 \\
(3.13-79.24)\end{array}$ \\
\hline $\begin{array}{l}\text { Indian } \\
\text { subcontinent }\end{array}$ & $31^{*}$ & 18 (58.1) & $\begin{array}{l}26.22 \\
(2.86-240.18)\end{array}$ & $10(32.3)$ & $\begin{array}{l}0.71 \\
(0.18-2.71)\end{array}$ & $19(61.3)$ & $\begin{array}{l}9.23 \\
(1.94-43.87)\end{array}$ \\
\hline $\begin{array}{l}\text { Northern } \\
\text { Africa }\end{array}$ & $16^{*}$ & $5(31.3)$ & $\begin{array}{l}7.28 \\
(0.70-75.92)\end{array}$ & $5(31.3)$ & $\begin{array}{l}0.64 \\
(0.14-2.98)\end{array}$ & $7(43.8)$ & $\begin{array}{l}2.90 \\
(0.54-15.57)\end{array}$ \\
\hline $\begin{array}{l}\text { Southern } \\
\text { Africa }\end{array}$ & $17^{*}$ & $529.4)$ & $\begin{array}{l}5.57 \\
(0.56-55.77)\end{array}$ & $5(29.4)$ & $\begin{array}{l}0.65 \\
(0.15-2.84)\end{array}$ & $6(35.3)$ & $\begin{array}{l}2.41 \\
(0.46-12.66)\end{array}$ \\
\hline Age (years) & 122 & & $\begin{array}{l}1.00 \\
(0.96-1.03)\end{array}$ & & $\begin{array}{l}1.01 \\
(0.98-1.04)\end{array}$ & & $\begin{array}{l}1.00 \\
(0.97-1.04)\end{array}$ \\
\hline $\begin{array}{l}\text { Travel duration } \\
\text { (days) }\end{array}$ & 122 & & $\begin{array}{l}1.00 \\
(0.98-1.01)\end{array}$ & & $\begin{array}{l}1.00 \\
(0.99-1.02)\end{array}$ & & $\begin{array}{l}1.00 \\
(0.98-1.01)\end{array}$ \\
\hline \multicolumn{8}{|l|}{ Sex } \\
\hline Female $\ddagger$ & 71 & $25(35.2)$ & 1.00 & $25(35.2)$ & 1.00 & 41 (57.7) & 1.00 \\
\hline Male & 51 & $13(25.5)$ & $\begin{array}{l}0.62 \\
(0.23-1.67)\end{array}$ & $15(29.4)$ & $\begin{array}{l}1.06 \\
(0.44-2.57)\end{array}$ & $21(41.2)$ & $\begin{array}{l}0.39 \\
(0.15-1.00)\end{array}$ \\
\hline \multicolumn{8}{|l|}{ Antibiotic use } \\
\hline Noł & 107 & 32 (29.9) & 1.00 & $35(32.7)$ & 1.00 & $52(48.6)$ & 1.00 \\
\hline Yes & 15 & $6(40.0)$ & $\begin{array}{l}1.44 \\
(0.40-5.25)\end{array}$ & $5(33.3)$ & $\begin{array}{l}1.28 \\
(0.36-4.51)\end{array}$ & $10(66.7)$ & $\begin{array}{l}1.64 \\
(0.43-6.22)\end{array}$ \\
\hline $\begin{array}{l}\text { Traveler's } \\
\text { diarrhea }\end{array}$ & 77 & $20(26.0)$ & 1.00 & $25(32.5)$ & 1.00 & $40(51.9)$ & 1.00 \\
\hline $\begin{array}{l}\text { Noł } \\
\text { Yes }\end{array}$ & 45 & $18(40.0)$ & $\begin{array}{l}1.84 \\
(0.70-4.82)\end{array}$ & $15(33.3)$ & $\begin{array}{l}0.97 \\
(0.40-2.37)\end{array}$ & 22 (48.9) & $\begin{array}{l}0.65 \\
(0.26-1.63)\end{array}$ \\
\hline
\end{tabular}

*Numbers do not add up to 122 , because the 14 travelers visiting multiple or unknown regions were added to a remainder category not included in this table.

tOdds ratios and $95 \%$ confidence intervals of the associations between risk factor and acquisition of resistance gene (negative pre-travel and positive post-travel) by multivariable logistic regression analysis. Models included the following variables: travel destination, age, travel duration, sex, antibiotic use within 3 months preceding the travel and traveler's diarrhea.

$¥$ Reference category.

$\S$ Europe and America, previously reported non-high risk regions, were pooled in order to establish an adequately sized reference category.

Boldface indicates a significant result. 
Table 4. CTX-M groups of the acquired genes during travels by 122

Dutch travelers per region

\begin{tabular}{lcccc}
\hline & \multicolumn{4}{c}{ CTX-M-group } \\
\cline { 2 - 5 } Region & 1 & 2 & 9 & $8 / 25$ \\
\hline SE Asia & 2 & 1 & 3 & 0 \\
Indian subcontinent & 15 & 0 & 2 & 3 \\
Northern Africa & 3 & 0 & 1 & 1 \\
Southern Africa & 2 & 0 & 0 & 3 \\
Southern Europe & 0 & 1 & 0 & 0 \\
Others & 2 & 0 & 0 & 2 \\
& & & & \\
Total & 24 & 4 & 6 & 9 \\
\hline
\end{tabular}

Table 5. Associations between acquisitions of bla $a_{\mathrm{CTX}-\mathrm{M}}$ and $q$ anrB or $q$ nrs during travels by 122 travelers from The Netherlands

\begin{tabular}{lrrrrrr}
\hline & & \multicolumn{2}{c}{$q n r B$ acquisition } & & \multicolumn{2}{c}{$q n r S$ acquisition } \\
\cline { 3 - 4 } \cline { 6 - 7 } & no & no & yes & & no & yes \\
\hline bla $a_{\text {CTX-M }}$ & 59 & 25 & & 46 & 38 \\
acquisition & & $70.2 \%$ & $29.8 \%$ & & $54.8 \%$ & $45.2 \%$ \\
& & & & & & \\
& yes & 23 & 15 & & 14 & 24 \\
& & $60.5 \%$ & $39.5 \%$ & & $39.8 \%$ & $63.2 \%$ \\
\hline
\end{tabular}




\section{Discussion}

In this study, we describe the use of a metagenomic approach to study effects of international travel on (a part of) the resistome of the human gut microbiota. Our results provide insights in the prevalence of the investigated resistance genes in the human gut microbiota and demonstrate high acquisition rates of the ESBL encoding gene $b / a_{\mathrm{CTX}-\mathrm{M}}$ and quinolone resistance encoding genes qnr $B$ and $q n r S$ as a result of international travel. Of note, the prevalence of these genes rose from $9.0 \%, 6.6 \%$ and $8.2 \%$ pre-travel to $33.6 \%, 36.9 \%$ and $55.7 \%$ post-travel respectively.

In the prospective cohort studies among Australian,[13] Dutch[16] and Swedish $[14,15]$ travelers, it was shown that international travel is indeed a risk factor for colonization with ESBL-producing Enterobacteriaceae, and that travel to India or the Indian subcontinent was the highest risk factor. These findings are in line with the acquisition rates of bla $a_{\mathrm{CTX}-\mathrm{M}}$, as found in our study, which were highest for travelers to the Indian subcontinent.

The phylogenetic types of the bla $a_{\text {CTX-M }}$ gene, which were acquired in our study group, were clearly dominated by CTX-M group 1, especially in the Indian subcontinent. This also corresponds with the earlier performed cohort studies which show that the colonization with ESBL-producing Enterobacteriaceae after travel to India or the Indian subcontinent are mainly those of CTX-M group 1 [1315]. While the power of our study was insufficient to conduct statistical analyses for the specific CTX-M groups, it was striking that acquisition of genes of the CTXM-2 group was detected twice and those of group 8 or 25 was detected 9 times. In previous studies, these CTX-M groups were not detected at all $[13,14]$, or only sporadically $[15,16]$. The difference in results could potentially be caused by our use of a metagenomic approach, which might detect $b / a_{\text {CTX-M }}$ in a much wider array of species than studies investigating specific cultured Enterobacteriaceae species. This difference in approach might furthermore explain that of the $b / a_{\mathrm{CTX}-\mathrm{M}}$ genes detected pre-travel in our study population, the majority $(9 / 11 ; 81.8 \%)$ were of the CTX-M-9 group, which contrasts studies which report that bla $a_{\mathrm{CTX}-\mathrm{M}-15}$ (which belongs to the CTX-M-1 group) is predominant in ESBL-producing Enterobacteriaceae in The Netherlands [16, 25, 26]. Aside from the different methodology used, it should also be noted, that the population size in these studies was larger than the one in our current study. 
Plasmid mediated quinolone resistance (PMQR) genes such as the qnr variants provide low-level quinolone resistance. However, these genes are relevant since they facilitate the emergence of higher-level resistance and thus can speed up the development and spread of resistance to these antimicrobial agents [27]. While foreign travel has been associated with the acquisition of PMQR positive isolates [28-30], these genes have thus far not been focused on in prospective cohort studies investigating the effects of travel on antibiotic resistance.

An interesting study by Vien et al. investigated the prevalence of the qnr genes in fecal swabs of children in Vietnam presenting with an acute respiratory tract infection [24], and showed a very high qnrS prevalence of $74.5 \%$. Travel to areas with such a high prevalence could therefore well be a major risk factor for acquisition of these genes. Interestingly, 5 out of 6 (83.3\%) participants in our study who had been to Vietnam during their travels had acquired a gnrS gene. In total, 11 volunteers had traveled to Cambodia, Thailand, Vietnam or a combination of these countries (which are geographically neighboring) and 9 $(81.8 \%)$ had acquired a qnrS gene. These data suggest that organisms carrying the qnrS gene have a high prevalence in these areas and that travelers visiting these areas have a high risk of being exposed to those organisms.

Co-existence of qnr genes with various other resistance genes, such as bla $a_{\text {CTX-M }}$, on the same plasmid is a well-known phenomenon [31-34] and could play a role in the fact that both these type of genes were found to be more prevalent in our post-travel samples. However, no association between these genes was found in our samples. The qnrS gene was most often acquired by travelers who visited SE Asia, and to a lesser extend the Indian subcontinent, whereas the acquisition rate for bla $a_{\text {CTX-M }}$ was clearly the highest for the Indian subcontinent, but was not found to be higher for SE Asia compared to other regions. This indicates that while travel to the Indian subcontinent is a high risk factor for acquiring both these genes, these risk factors are not necessarily related.

While the use of a metagenomic approach has the advantage of being able to detect resistance in a much wider array of species compared to culturing methods, a limitation is that it is not yet known in which organisms the acquired resistance genes detected in our study are present, nor if they are being expressed. Another limitation of our study is that our population size was not large enough to perform a more extensive risk analysis. Future studies would benefit from larger population sizes in order to conduct more extensive analyses for risk factors such as antibiotic usage, travel destination and duration of travels. 
Furthermore, in future studies it would be highly relevant to include a follow-up sampling of the traveling participants in order to also focus on investigating the time span that these acquired resistance genes remain in the resistome, and if the perseverance or even HGT of these genes in the resistome over time is promoted by e.g. selective pressure introduced by antibiotic usage. To date, little is known about the duration that resistant organisms acquired by travel remain in ones microbiota, while this plays a key role in the ability to further spread these organisms or resistance elements.

By investigating several targeted resistance genes, it became evident that resistance genes from foreign environments are being introduced into the gut resistome at high rates as a result of international travel. While the consequences of these changes in the resistome are difficult to predict, the introduction of these genes into the genetic pool of resistance elements may create opportunities for the horizontal transfer to other organisms in the gut microbiota.

In conclusion, our data demonstrate an increasing prevalence of bla $a_{\mathrm{CTX}-\mathrm{M}}, q n r B$ and gnrS genes in the stools of healthy Dutch volunteers directly after they had been on an international travel. These findings contribute to the increasing evidence that travelers are aiding in the spread of antimicrobial resistance.

\section{Acknowledgements}

We thank Mayk Lucchesi for his work in the processing and storage of the stool samples. 


\section{References}

1. Wright GD. The antibiotic resistome. Expert Opin Drug Discov. 2010;5(8):779-88.

2. Zhou W, Wang Y, Lin J. Functional cloning and characterization of antibiotic resistance genes from the chicken gut microbiome. Appl Environ Microbiol. 2012;78(8):3028-32.

3. Cheng G, Hu Y, Yin Y, Yang X, Xiang C, Wang B, et al. Functional screening of antibiotic resistance genes from human gut microbiota reveals a novel gene fusion. FEMS Microbiol Lett. 2012;336(1):11-6.

4. Torres-Cortes G, Millan V, Ramirez-Saad HC, Nisa-Martinez R, Toro N, MartinezAbarca F. Characterization of novel antibiotic resistance genes identified by functional metagenomics on soil samples. Environ Microbiol. 2011;13(4):1101-14.

5. Sommer MO, Dantas G, Church GM. Functional characterization of the antibiotic resistance reservoir in the human microflora. Science. 2009;325(5944):1128-31.

6. Wright GD. Antibiotic resistance in the environment: a link to the clinic? Curr Opin Microbiol. 2010;13(5):589-94.

7. Poirel L, Rodriguez-Martinez JM, Mammeri H, Liard A, Nordmann P. Origin of plasmid-mediated quinolone resistance determinant QnrA. Antimicrob Agents Chemother. 2005;49(8):3523-5.

8. Poirel L, Kampfer P, Nordmann P. Chromosome-encoded Ambler class A betalactamase of Kluyvera georgiana, a probable progenitor of a subgroup of CTX-M extended-spectrum beta-lactamases. Antimicrob Agents Chemother. 2002;46(12):4038-40.

9. Penders J, Stobberingh EE, Savelkoul PH, Wolffs PF. The human microbiome as a reservoir of antimicrobial resistance. Front Microbiol. 2013;4:87.

10. Baquero F. Metagenomic epidemiology: a public health need for the control of antimicrobial resistance. Clin Microbiol Infect. 2012;18 Suppl 4:67-73.

11. Eckburg PB, Bik EM, Bernstein CN, Purdom E, Dethlefsen L, Sargent M, et al. Diversity of the human intestinal microbial flora. Science. 2005;308(5728):1635-8.

12. van der Bij AK, Pitout JD. The role of international travel in the worldwide spread of multiresistant Enterobacteriaceae. J Antimicrob Chemother. 2012;67(9):2090-100.

13. Kennedy K, Collignon P. Colonisation with Escherichia coli resistant to "critically important" antibiotics: a high risk for international travellers. Eur J Clin Microbiol Infect Dis. 2010;29(12):1501-6.

14. Tangden $T$, Cars O, Melhus A, Lowdin E. Foreign travel is a major risk factor for colonization with Escherichia coli producing CTX-M-type extended-spectrum betalactamases: a prospective study with Swedish volunteers. Antimicrob Agents Chemother. 2010;54(9):3564-8.

15. Ostholm-Balkhed A, Tarnberg M, Nilsson M, Nilsson LE, Hanberger $H$, Hallgren A, et al. Travel-associated faecal colonization with ESBL-producing Enterobacteriaceae: incidence and risk factors. J Antimicrob Chemother. 2013;68(9):2144-53.

16. Paltansing S, Vlot JA, Kraakman MEM, Mesman R, Bruijning ML, Bernards AT, et al. Extended-Spectrum $\beta$-Lactamase-producing Enterobacteriaceae among Travelers from the Netherlands. Emerg Infect Dis. 2013;19(8):1206-13.

17. Collignon P. Resistant Escherichia coli--we are what we eat. Clin Infect Dis. 2009;49(2):202-4. 
18. Pfaffl MW. A new mathematical model for relative quantification in real-time RT-PCR. Nucleic Acids Res. 2001;29(9):e45.

19. Vliegen I, Jacobs JA, Beuken E, Bruggeman CA, Vink C. Rapid identification of bacteria by real-time amplification and sequencing of the $16 \mathrm{~S}$ rRNA gene. J Microbiol Methods. 2006;66(1):156-64.

20. Kim SM, Kim HC, Lee SW. Characterization of antibiotic resistance determinants in oral biofilms. J Microbiol. 2011;49(4):595-602.

21. Martineau F, Picard FJ, Lansac N, Menard C, Roy PH, Ouellette M, et al. Correlation between the resistance genotype determined by multiplex PCR assays and the antibiotic susceptibility patterns of Staphylococcus aureus and Staphylococcus epidermidis. Antimicrob Agents Chemother. 2000;44(2):231-8.

22. Birkett $\mathrm{Cl}$, Ludlam HA, Woodford N, Brown DF, Brown NM, Roberts MT, et al. Realtime TaqMan PCR for rapid detection and typing of genes encoding CTX-M extendedspectrum beta-lactamases. J Med Microbiol. 2007;56(Pt 1):52-5.

23. Naas T, Ergani A, Carrer A, Nordmann P. Real-time PCR for detection of NDM-1 carbapenemase genes from spiked stool samples. Antimicrob Agents Chemother. 2011;55(9):4038-43.

24. Vien le TM, Minh NN, Thuong TC, Khuong HD, Nga TV, Thompson C, et al. The coselection of fluoroquinolone resistance genes in the gut flora of Vietnamese children. PLoS ONE. 2012;7(8):e42919.

25. Leverstein-van Hall MA, Dierikx CM, Cohen Stuart J, Voets GM, van den Munckhof $M P$, van Essen-Zandbergen $A$, et al. Dutch patients, retail chicken meat and poultry share the same ESBL genes, plasmids and strains. Clin Microbiol Infect. 2011;17(6):873-80.

26. Reuland EA, Overdevest IT, AI Naiemi N, Kalpoe JS, Rijnsburger MC, Raadsen SA, et al. High prevalence of ESBL-producing Enterobacteriaceae carriage in Dutch community patients with gastrointestinal complaints. Clin Microbiol Infect. 2013;19(6):542-9.

27. Martinez-Martinez L, Pascual A, Jacoby GA. Quinolone resistance from a transferable plasmid. Lancet. 1998;351(9105):797-9.

28. Hopkins KL, Wootton L, Day MR, Threlfall EJ. Plasmid-mediated quinolone resistance determinant qnrS1 found in Salmonella enterica strains isolated in the UK. J Antimicrob Chemother. 2007;59(6):1071-5.

29. Karczmarczyk M, Stephan R, Hachler H, Fanning S. Complete nucleotide sequence of pVQS1 containing a quinolone resistance determinant from Salmonella enterica serovar Virchow associated with foreign travel. J Antimicrob Chemother. 2012;67(8):1861-4.

30. Taguchi M, Kawahara R, Seto K, Inoue K, Hayashi A, Yamagata N, et al. Plasmidmediated quinolone resistance in Salmonella isolated from patients with overseas travelers' diarrhea in Japan. Jpn J Infect Dis. 2009;62(4):312-4.

31. Kanamori H, Yano H, Hirakata $Y$, Hirotani A, Arai K, Endo S, et al. Molecular characteristics of extended-spectrum beta-lactamases and qnr determinants in Enterobacter species from Japan. PLoS ONE. 2012;7(6):e37967.

32. Strahilevitz J, Jacoby GA, Hooper DC, Robicsek A. Plasmid-mediated quinolone resistance: a multifaceted threat. Clin Microbiol Rev. 2009;22(4):664-89.

33. Jiang Y, Zhou Z, Qian Y, Wei Z, Yu Y, Hu S, et al. Plasmid-mediated quinolone resistance determinants qnr and aac(6')-lb-cr in extended-spectrum beta-lactamase- 
producing Escherichia coli and Klebsiella pneumoniae in China. J Antimicrob Chemother. 2008;61(5):1003-6.

34. Dahmen S, Poirel L, Mansour W, Bouallegue O, Nordmann P. Prevalence of plasmidmediated quinolone resistance determinants in Enterobacteriaceae from Tunisia. Clin Microbiol Infect. 2010;16(7):1019-23. 


\section{Chapter 4B}

Longitudinal fluctuations of common antimicrobial resistance genes in the gut microbiomes of healthy Dutch individuals

Jakob Malin, Christian J.H. von Wintersdorff, John Penders,

Paul H.M. Savelkoul \& Petra F.G. Wolffs

Manuscript in preparation 


\section{Abstract}

The human microbiome is an important reservoir of antimicrobial resistance genes, collectively termed the resistome. So far, few studies have examined the dynamics of the human gut resistome in healthy individuals. We aimed to provide insight into the dynamics of the human gut resistome by investigating the presence and abundance of several antimicrobial resistance genes (ARGs) in faecal samples of a group of healthy volunteers at three different time points. Moreover, we placed these normally occurring fluctuations into context of our previous findings on the shifts in the resistome of international travellers.

Faecal samples from 23 healthy, non-travelling participants were collected at baseline and subsequently 2 and 4 weeks after inclusion. DNA was subsequently isolated from these samples and subjected to $\mathrm{GPCR}$ for the detection and quantification of several ARGs.

For the highly prevalent ARGs $c f x A$, tetM, and ermB we found no significant differences in the fluctuations in abundance of our group compared to the group of travellers ( $p=0.71,0.18$ and 0.91 , respectively). For $b / a_{\text {CTX-M }}$ and $q n r B$, a prevalence of $17.4 \%$ and $5.7 \%$ was observed ( $11.6 \%$ and $2.9 \%$ of all samples). In two cases acquisition of a bla $a_{\text {CTX-M }}$ gene and in one case acquisition of a qnrB gene was observed during follow-up of the study. While no sample was positive for vanA or qnrS, very high rates of vanB (78.3\%) were observed at all time points.

In conclusion, we showed that fluctuations in the abundance of ARGs which are highly prevalent in the human gut microbiome is a common occurrence, not related to international travel. 


\section{Introduction}

Bacterial resistance to antimicrobials is a major concern in healthcare. Longtime, vertical evolution within clinically relevant pathogens was thought to be the major cause of emerging antibiotic resistance. Research therefore mainly focused on resistance in pathogenic bacteria. However, there is a growing body of evidence that environmental and commensal bacteria comprise an enormous and mostly unexplored reservoir of antibiotic resistance genes (ARGs) [1-4]. Because of horizontal gene transfer (HGT) these genes are potentially transferable to bacteria of the same or other species and genera, including relevant pathogens [5, 6]. For several clinically relevant resistance genes such transfer has actually been described [7-9].

The human gut microbiome has gained special attention as reservoir of ARGs, potentially promoting the emergence of resistant pathogens [10-12]. The high density of microorganisms and biofilms in the gut in combination with its accessibility and constant exposure to various bacteria and genetic material from food, water, soil and even intestinal organisms from other hosts provide favourable conditions for resistance gene transfer to take place [11, 12]. The gut can therefore be described as a 'genetic-genomic-metagenomic reactor' [11]. In fact, sequencing of the gut metagenomes of 162 individuals revealed 1.093 ARGs in a total of 4.1 million scanned genes [4]. In addition to that, the ARGs ermB and b12e_cfxa, conferring resistance to respectively erythromycin and cephalosporin were found in nearly all samples. More recently, another study with 275 individuals of different age groups and seven different nationalities revealed resistance to 53 antibiotics. Resistance genes to tetracycline (tet $Q$ and tetM), bacitracin ( $b a c A$ / uppP and $b c r A$ ) and vancomycin (vanUG, vanG and vanRG) were found in nearly all gut metagenomes [13]. While metagenomic studies confirm richness and diversity of AGRs within the human gut microbiome, horizontal gene transfer of the ARGs in the gut microbiome has already been demonstrated in relatively small in vivo experiments between species of Enterococcus faecium [14] and species of E. coli [15]. In addition, there is mounting evidence for the clinical importance of HGT in the lower gastrointestinal tract, including several case reports demonstrating the occurrence of HGT in the gut of patients [16-21].

In a previous study of the gut resistome of 122 travellers from the Netherlands it was shown that international travel is associated with the acquisition of different ARGs genes. Moreover, changes in the relative abundance of the 
tetracycline-, erythromycin- and ß-lactam resistance encoding genes tet $M$, ermB and cfxA between pre- and post-travel stool samples was observed [22]. However, little is known about changes within the resistome that takes place without exposure to factors associated with the selection or acquisition of antibiotic resistance (e.g. international travel, antibiotic usage). In this study we aimed to investigate normal longitudinal fluctuations in the abundance of several ARGs within the human gut metagenome of healthy volunteers and contrast them to previous findings in travelling individuals.

\section{Materials \& methods}

\section{Population and design}

Consenting healthy volunteers ( $>18$ years of age) were recruited between December 2014 and January 2015. Volunteers that had used antimicrobial agents in the past month or had travelled to regions outside Europe or North America in the past 3 months prior to the start of the study were excluded. Participants were asked to collect a total of 3 faecal samples at baseline and subsequently 2 and 4 weeks after inclusion (T0, T1 and $\mathrm{T} 2$ respectively). At each collection time point subjects were asked to fill in a questionnaire on antibiotic- and/or probiotics usage, travelling behaviour and whether they experienced any episodes of diarrhoea (defined according to the WHO as the passage of 3 or more loose or liquid stools per day, or more frequently than is normal for the individual) in the past two weeks. Participants that used antibiotics/probiotics, experienced diarrheal episodes or travelled outside of a neighbouring country during follow-up were subsequently excluded from the analysis. The faecal samples together with the questionnaires were sent by regular mail to the laboratory at the same day of collection or were admitted to a central collection point and were processed in the lab on the day of receipt. 


\section{Faecal specimen processing and DNA extraction}

Faecal samples remained at room temperature for a maximum of 48 hours, after which they were diluted 10-fold in a peptone/water solution (Oxoid, Basingstoke, UK) containing 20\% glycerol (Merck, Darmstadt, Germany). After homogenizing by vortexing, samples were stored at $-20^{\circ} \mathrm{C}$ until extraction of DNA was performed. DNA extraction was performed as described earlier [22]. DNA samples were stored at $-20^{\circ} \mathrm{C}$ until molecular analysis.

\section{Real-time PCR}

Real-Time PCR was used to detect and quantify all resistance genes as described earlier [22]. In addition, a multiplex TaqMan assay for the detection of vanA and $v a n B$ and $E$. faecium genes was used for the detection of vancomycin resistance genes. Primer and probe sequences were as follows: 5'GCCGGAAAAAGGCTCTGAA-3' (forward), 5'-TCCTCGCTCCTCTGCTGAA-3' (reverse), 5'-FAM-ACGCAGTTATAACCGTTCCCGCAGACC-BHQ2-3' (probe) for vanA; 5'CGCAGCTTGCATGGACAA-3' (forward), 5'-GGCGATGCCCGCATT-3' (reverse), 5'-VIC -TCACTGGCCTACATTC- MGBNFQ-3' (probe) for vanB; and 5'GGAATGGCGCAAAACTTAGA -3' (forward), 5'- AGGCCTCTCCAACTGGAACT -3' (reverse), 5'-NED-TGGCGATTTCGAGTCCATTCG-BHQ1-3'-TAMRA (probe) for $E$. faecium. Reactions were performed on a 7900HT Fast Real-Time PCR System (Thermo Fisher Scientific, Waltham, MA, USA) in $25 \mu \mathrm{l}$, containing $12.5 \mu \mathrm{l}$ ABsolute QPCR ROX Mix (Thermo Scientific), $5 \mu$ template DNA, $800 \mathrm{nM}$ of each primer and $200 \mathrm{nM}$ of each probe. The cycling conditions were 15 minutes at $95^{\circ} \mathrm{C}$, followed by 42 cycles of 15 seconds at $95^{\circ} \mathrm{C}$ and 60 seconds at $60^{\circ} \mathrm{C}$

\section{Quantification of ARGs}

For absolute quantification, control plasmids were created by cloning the corresponding PCR amplicons into a pGEM-T easy vector (Promega Corporation, Madison, WI, USA) according to the manufacturer's protocol. Plasmids were isolated using standard alkaline lysis, after which these products were subjected to gel-electrophoresis, followed by excision of the target plasmids from the electrophoresis gel and purified using a GenElute ${ }^{\mathrm{TM}}$ Gel Extraction Kit (SigmaAldrich). The resulting plasmids were subsequently sequenced on an $A B I 3730$ DNA Analyzer (Thermo Fisher Scientific) by using the PCR primers and an ABI BigDye Terminator v.1.1 Cycle Sequencing Kit (Thermo Fisher Scientific). Analysis 
of resultant amplicon sequences using BLAST (http://blast.ncbi.nlm.nih.gov/ Blast.cgi) confirmed identity to the respective ARGs. Concentrations of purified plasmids were determined using a NanoDrop 2000 UV-Vis spectrophotometer (Thermo Scientific) before quantitative PCR was performed on log-fold dilution series of the plasmid solutions to generate standard curves for quantification of copy numbers.

\section{Statistical analysis}

Copy numbers of ARGs within all samples were calculated by interpolation from the respective standard curves. To correct for the total amount of bacterial DNA within each sample these numbers were referred to the amount of 16S rDNA by dividing ARG copy numbers by that of the $16 \mathrm{~S}$ rDNA. For one group of genes (cfxA, tet $M$ and ermB) that is highly prevalent in the studied population, fluctuations in gene abundance were plotted on an $x / y$ graph as ratios (figure 2). Values that appeared as 0 copies because of undetectable targets in the PCR reaction were transformed to 0.01 (origin of the axis) to allow for the use of logscales in this figure. This was done for 17 values in the travellers group ( $1 \times \operatorname{tetM}, 2$ $\mathrm{x}$ ermB, $14 \times(f \times A)$ and these values were excluded from subsequent statistical analysis. To analyse differences between our group and the travellers, copy numbers were $\log$-transformed $(z=\log (y / x)=\log (y)-\log (x))$ and analysed for differences in mean and variance. We chose nonparametric testing because of failing to statistically confirm Gaussian distributions despite transformation. Twosided Mann-Whitney tests were performed to look for differences in distributions. For the less prevalent ARGs (bla $a_{\mathrm{CTX}-\mathrm{M}}, \operatorname{vanA} / \mathrm{B}, \mathrm{qnr} B$ and $q n r S$ ), only the prevalence at the different time points was calculated. 


\section{Results}

\section{Study population}

Initially 25 adult healthy volunteers (14 men, 11 women) were included, of which 2 subjects had to be excluded because of international travel during the 4 weeks follow-up. As such, the final study population consists of 23 subjects.

Admission of samples by mail was chosen by seven individuals, while sixteen subjects delivered their samples directly to the laboratory. Five participants reported diarrhoea on a minimum of one questionnaire. No participant reported of antimicrobial- or probiotic supplement use during the study period (table 1 ).

Table 1. Characteristics of both the non-travelling and travelling study populations.

\begin{tabular}{lll}
\hline Characteristic & $\begin{array}{l}\text { Non-travellers } \\
(\mathrm{N}=23)\end{array}$ & $\begin{array}{c}\text { Travellers }^{\mathrm{a}} \\
(\mathrm{N}=122)\end{array}$ \\
\hline Age (years) & \begin{tabular}{l} 
Median (range) \\
\cline { 2 - 3 }
\end{tabular} & $43(18-72)$ \\
Sex & No. $(\%)$ & \\
\cline { 2 - 3 } Female & $11(47.8)$ & $71(58.2)$ \\
$\quad$ Male & $12(52.2)$ & $51(41.8)$ \\
Diarrhea within study period & $5(21.7)$ & $45(36.9)$ \\
Antimicrobial drug use & $0(0)$ & $15(12.3)$ \\
Probiotic supplement use & $0(0)$ & N.D. \\
Sample Admission route & & $122(100.0)$ \\
$\quad \begin{array}{l}\text { Mail } \\
\text { Direct }\end{array}$ & $7(30.4)$ & $0(0.0)$ \\
\hline
\end{tabular}

N.D., Not determined.

${ }^{a}$ population from a previously performed study [22].

\section{Prevalence of ARGs in faecal samples}

Figure 1 shows the prevalence of the ARGs in faecal samples from the 23 healthy volunteers at three consecutive time points. The $c f x A$, tetM and ermB genes were detected in all faecal samples. The ESBL encoding $b / a_{\text {CTX-M }}$ was detected in two $(8.7 \%)$ samples at T0, three $(13 \%)$ at T1 and four $(17.4 \%)$ at T3. The $q n r B$ gene was detected in one (4.3\%) sample at T0, none of the samples at $\mathrm{T} 2$ and again in another sample (4.3\%) at T2. VanA and qnrS were undetectable in all samples. For the glycopeptide resistance encoding gene vanB we found 17 (73.9\%) positive samples at each time point (TO to T2). 


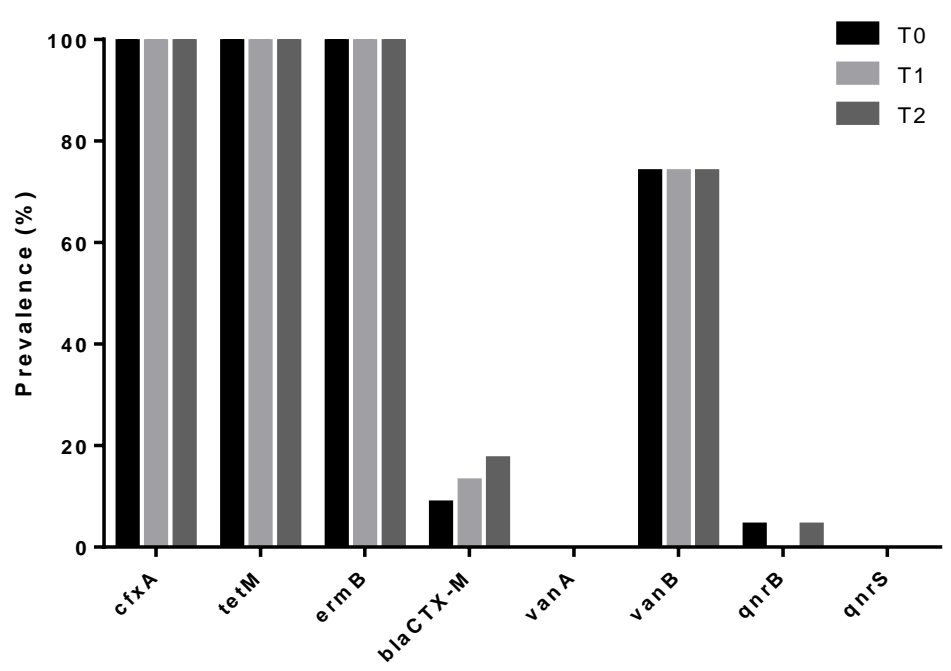

Figure 1. Prevalence (\%) of ARG determinants in faecal samples from 23 healthy volunteers.

\section{Acquisition and loss of ARGs}

Acquisition or loss of $b / a_{\text {CTX-M }}, q n r B$ and $q n r S$ was detected in a few individuals. One individual's faecal sample became positive for both bla $a_{\mathrm{CTX}-\mathrm{M}}$ and $q n r B$ on T2, while the samples were negative at TO. For another individual, the $b / a_{\text {CTX-M }}$ gene was absent in T0, but detectable at T1 and T2. One individual had lost the qnrB gene at $\mathrm{T} 1$, as it was no longer detected since then. For $\operatorname{Van} B$, one acquisition at $\mathrm{T} 1$ and one loss at $\mathrm{T} 1$ was observed.

\section{Fluctuations in gene abundance}

Changes in the abundance of the highly prevalent ARGs in the study population varied between a -36.55 to 9.21 (median of 1.04) fold change for $c f x A$, a -4.48 to 11.38 (median of -1.14 ) fold change for tetM and a -10.23 to 4.94 (median of 1.04) fold change for ermB. This is in line with earlier determined changes in the ARG abundance for the travelling group, median fold changes 1.00, -1.35 and 1.04 for cfxA, tetM and ermB respectively.

In order to visualize the changes in ARG abundance in our study group and compare it to the changes in the travelling group, fluctuations from T0 to T1 and 
T1 to T2 of the non-travelling participants were plotted as pooled ratios of ARG abundance (Figure 2A, C, E) and compared to the fluctuations that were observed in the group of travellers where the abundance before travel is plotted against the abundance after travel (Figure 2B, D, F). No significant differences in fluctuations of $c f x A$, tet $M$ and ermB were seen between the two groups $(p=0.71,0.18$ and 0.91 , respectively). Fluctuations in tet $M$ gene abundance (both increases and decreases) visually appeared to be larger in the travellers group (SD 1.7) compared to healthy volunteers (SD 11.47), however because of the non-Gaussian nature of the data we did not test on differences in variance with parametric tests. In the five samples where participants reported of diarrhoea in the past 2 weeks, no differences in $16 \mathrm{~S}$ rDNA load or ARG abundance was seen as compared to the other samples. 

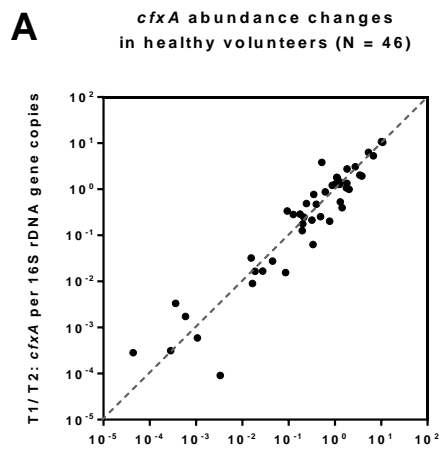

T0/T1: cfXA per 16S rDNA gene copies

C tetM abundance changes
in healthy volunteers $(\mathrm{N}=46)$

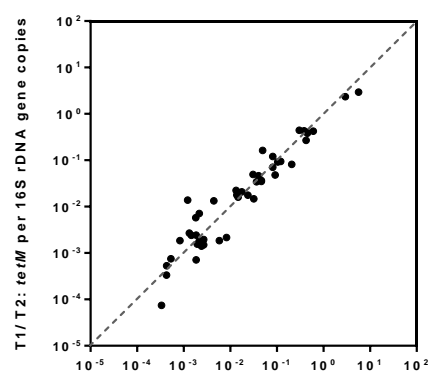

T0/T1: tetM per 16S rDNA gene copies
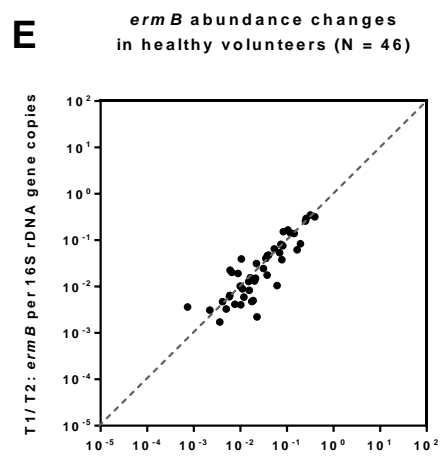

T0/T1: ermB per 16S rDNA gene copies
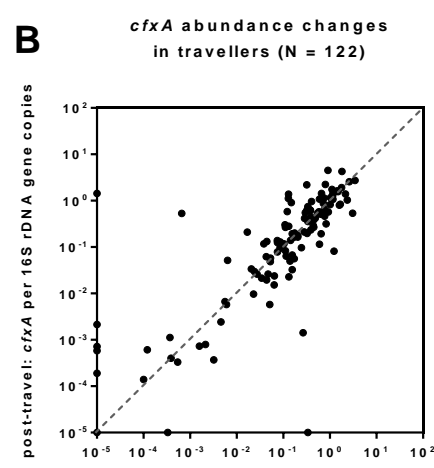

pre-travel: cfxA per $16 \mathrm{~S}$ rDNA gene copies
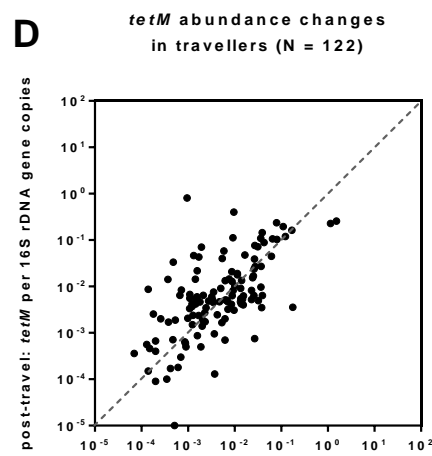

pre-travel: tetM per $16 \mathrm{~S}$ rDNA gene copies
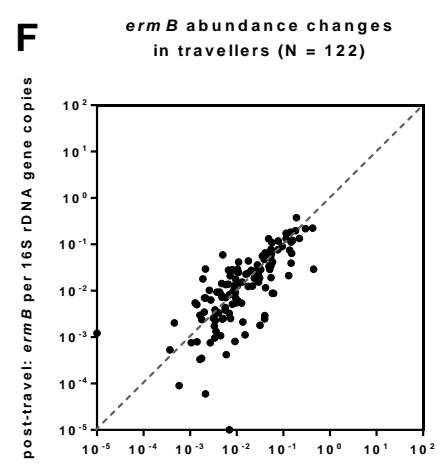

pre-travel: ermB per $16 \mathrm{~S}$ rDNA gene copies

Figure 2. Absolute changes in ARG abundance. $(A, C, E)$ Changes from T0 (x-axis) to T1 ( $y$-axis) pooled with changes from $T 1$ (x-axis) to $T 2$ ( $y$-axis) in comparison to (B, D, F) a group of international travellers before (x-axis) and after travel ( $y$-axis). Points located above the dashed line (---) indicate increases while points below this line represent decreased ARG abundances. Points that are located on one of the axis indicate acquisition (x-axis) and loss (y-axis) of ARGs. 


\section{Discussion}

With our study of short term fluctuations in the abundance of the analysed ARGs: $c f x A$, tet $M$ and ermB, we provide insights into the dynamics of the resistome of healthy adult individuals. Our findings suggest that relative changes in gene abundance that have previously been observed in travellers can be interpreted as normal fluctuations that take also place in healthy, non-travelling individuals. The metagenomic approach has the advantage that ARGs can be detected in a much wider array of species that also covers not cultivable bacteria. However, inherent limitations are that detected ARGs cannot be directly linked to specific organisms of the gut microbiota and it does not provide any information on functionality. The next challenge will be to determine factors that explain these fluctuations, such as e.g. changes in microbial composition or exposure to external sources of these genes.

Our study has some limitations. First, there were some differences in the two compared study populations. For example, there were slight differences in the proportion of antibiotic use and subjects suffering from self-reported diarrhoea, as well as the median age between the groups. Second, the small number of included individuals and the consequential pooling of changes in abundance from $\mathrm{TO}$ to $\mathrm{T} 1$ and $\mathrm{T} 1$ to $\mathrm{T} 2$ could have also contributed to more homologous data. The differences in variance of the fluctuations that were observed in tetM might be (partly) induced by these factors. Other possible explanations include minor differences in sampling methods and sample processing in the two studies as well as an effect of travelling on the abundance of this ARG. We also investigated the prevalence of the ESBL-encoding gene $b / a_{\mathrm{CTX}-\mathrm{M}}$, the quinolone resistance encoding genes $q n r B$ and $q n r S$ and the glycopeptide resistance encoding genes vanA and vanB at the different time points (T0-T2). Only few samples were positive for $b / a_{\text {CTX-M }}$ ( 8 for CTX-M group 1 and 1 for CTX-M group 2), two for qnrB and none for qnrS or vanA. This confirms the findings in the prior study where a low prevalence of these genes prior to travel was observed. We found a very high prevalence of vanB in our group and carriage of this ARG was highly consistent over the three time points. Carriage of vanB was however not associated with PCR detection of Enterococcus spp., indicating that the genes did not originate from vancomycin resistant enterococci (VRE). High rates of non-enterococcal vanB carriage in fecal samples have previously been described [23-25]. Several non-enterococcal organisms of the human gut microbiota harbouring the vanB genotype have been 
described and include species of the genus Clostridium [26, 27] and Streptococcus $[28,29]$. Molecular characterization of this prevalent $\operatorname{van} B$ genotype and genotypes of clinically isolated VRE as well as identification of carrying organisms and further transmission experiments are necessary to estimate the potential clinical implications that might follow an uncontrolled spread of this ARG.

In conclusion, we showed that fluctuations in the abundance of ARGs, which are highly prevalent in the human gut microbiome is common and not related to international travel. Further investigation could determine if such fluctuations are brought about by changes in the microbial composition of the gut. 


\section{References}

1. Zhou W, Wang $Y$, Lin J. Functional cloning and characterization of antibiotic resistance genes from the chicken gut microbiome. Appl Environ Microbiol. 2012;78(8):3028-32.

2. Cheng G, Hu Y, Yin Y, Yang X, Xiang C, Wang B, et al. Functional screening of antibiotic resistance genes from human gut microbiota reveals a novel gene fusion. FEMS Microbiol Lett. 2012;336(1):11-6.

3. Torres-Cortes G, Millan V, Ramirez-Saad HC, Nisa-Martinez R, Toro N, MartinezAbarca F. Characterization of novel antibiotic resistance genes identified by functional metagenomics on soil samples. Environ Microbiol. 2011;13(4):1101-14.

4. Sommer MO, Dantas G, Church GM. Functional characterization of the antibiotic resistance reservoir in the human microflora. Science. 2009;325(5944):1128-31.

5. Wright GD. The antibiotic resistome. Expert Opin Drug Discov. 2010;5(8):779-88.

6. Perry JA, Wright GD. The antibiotic resistance "mobilome": searching for the link between environment and clinic. Front Microbiol. 2013;4:138.

7. Poirel L, Rodriguez-Martinez JM, Mammeri H, Liard A, Nordmann P. Origin of plasmid-mediated quinolone resistance determinant QnrA. Antimicrob Agents Chemother. 2005;49(8):3523-5.

8. Poirel L, Kampfer P, Nordmann P. Chromosome-encoded Ambler class A betalactamase of Kluyvera georgiana, a probable progenitor of a subgroup of CTX-M extended-spectrum beta-lactamases. Antimicrob Agents Chemother. 2002;46(12):4038-40.

9. Goyal A, Prasad KN, Prasad A, Gupta S, Ghoshal U, Ayyagari A. Extended spectrum beta-lactamases in Escherichia coli \& Klebsiella pneumoniae \& associated risk factors. Indian J Med Res. 2009;129(6):695-700.

10. Huddleston JR. Horizontal gene transfer in the human gastrointestinal tract: potential spread of antibiotic resistance genes. Infect Drug Resist. 2014;7:167-76.

11. Baquero F. Metagenomic epidemiology: a public health need for the control of antimicrobial resistance. Clin Microbiol Infect. 2012;18 Suppl 4:67-73.

12. Penders J, Stobberingh EE, Savelkoul PH, Wolffs PF. The human microbiome as a reservoir of antimicrobial resistance. Front Microbiol. 2013;4:87.

13. Ghosh TS, Gupta SS, Nair GB, Mande SS. In silico analysis of antibiotic resistance genes in the gut microflora of individuals from diverse geographies and age-groups. PLoS ONE. 2013;8(12):e83823.

14. Lester $\mathrm{CH}$, Frimodt-Moller N, Sorensen TL, Monnet DL, Hammerum AM. In vivo transfer of the vanA resistance gene from an Enterococcus faecium isolate of animal origin to an $\mathrm{E}$. faecium isolate of human origin in the intestines of human volunteers. Antimicrob Agents Chemother. 2006;50(2):596-9.

15. Trobos $\mathrm{M}$, Lester $\mathrm{CH}$, Olsen JE, Frimodt-Moller $\mathrm{N}$, Hammerum AM. Natural transfer of sulphonamide and ampicillin resistance between Escherichia coli residing in the human intestine. J Antimicrob Chemother. 2009;63(1):80-6.

16. Cremet L, Bourigault C, Lepelletier D, Guillouzouic A, Juvin ME, Reynaud A, et al. Nosocomial outbreak of carbapenem-resistant Enterobacter cloacae highlighting the interspecies transferability of the blaOXA-48 gene in the gut flora. J Antimicrob Chemother. 2012;67(4):1041-3. 
17. Karami N, Martner A, Enne VI, Swerkersson S, Adlerberth I, Wold AE. Transfer of an ampicillin resistance gene between two Escherichia coli strains in the bowel microbiota of an infant treated with antibiotics. J Antimicrob Chemother. 2007;60(5):1142-5.

18. Goren MG, Carmeli Y, Schwaber MJ, Chmelnitsky I, Schechner V, Navon-Venezia S. Transfer of carbapenem-resistant plasmid from Klebsiella pneumoniae ST258 to Escherichia coli in patient. Emerg Infect Dis. 2010;16(6):1014-7.

19. Duval-Iflah $Y$, Raibaud P, Tancrede C, Rousseau M. R-plasmic transfer from Serratia liquefaciens to Escherichia coli in vitro and in vivo in the digestive tract of gnotobiotic mice associated with human fecal flora. Infect Immun. 1980;28(3):981-90.

20. Sparo M, Urbizu L, Solana MV, Pourcel G, Delpech G, Confalonieri A, et al. High-level resistance to gentamicin: genetic transfer between Enterococcus faecalis isolated from food of animal origin and human microbiota. Lett Appl Microbiol. 2012;54(2):119-25.

21. Lester $\mathrm{CH}$, Frimodt-Moller N, Hammerum AM. Conjugal transfer of aminoglycoside and macrolide resistance between Enterococcus faecium isolates in the intestine of streptomycin-treated mice. FEMS Microbiol Lett. 2004;235(2):385-91.

22. von Wintersdorff CJ, Penders J, Stobberingh EE, Oude Lashof AM, Hoebe CJ, Savelkoul PH, et al. High rates of antimicrobial drug resistance gene acquisition after international travel, The Netherlands. Emerg Infect Dis. 2014;20(4):649-57.

23. Graham M, Ballard SA, Grabsch EA, Johnson PD, Grayson ML. High rates of fecal carriage of nonenterococcal vanB in both children and adults. Antimicrob Agents Chemother. 2008;52(3):1195-7.

24. Domingo MC, Huletsky A, Giroux R, Boissinot K, Picard FJ, Lebel P, et al. High prevalence of glycopeptide resistance genes vanB, vanD, and van $G$ not associated with enterococci in human fecal flora. Antimicrob Agents Chemother. 2005;49(11):4784-6.

25. Ballard SA, Pertile KK, Lim M, Johnson PD, Grayson ML. Molecular characterization of vanB elements in naturally occurring gut anaerobes. Antimicrob Agents Chemother. 2005;49(5):1688-94.

26. Domingo MC, Huletsky A, Bernal A, Giroux R, Boudreau DK, Picard FJ, et al. Characterization of a Tn5382-like transposon containing the vanB2 gene cluster in a Clostridium strain isolated from human faeces. J Antimicrob Chemother. 2005;55(4):466-74.

27. Launay A, Ballard SA, Johnson PD, Grayson ML, Lambert T. Transfer of vancomycin resistance transposon Tn1549 from Clostridium symbiosum to Enterococcus spp. in the gut of gnotobiotic mice. Antimicrob Agents Chemother. 2006;50(3):1054-62.

28. Poyart C, Pierre C, Quesne G, Pron B, Berche P, Trieu-Cuot P. Emergence of vancomycin resistance in the genus Streptococcus: characterization of a van $B$ transferable determinant in Streptococcus bovis. Antimicrob Agents Chemother. 1997;41(1):24-9.

29. Dahl KH, Sundsfjord A. Transferable vanB2 Tn5382-containing elements in fecal streptococcal strains from veal calves. Antimicrob Agents Chemother. 2003;47(8):2579-83. 


\section{Chapter 5}

\section{Acquisition of travel-associated antibiotic resistant bacteria occurs within several days}

Christian J.H. von Wintersdorff, Nathan D. Mills, John Penders, D. Tedjo, Paul H.M. Savelkoul \& Petra F.G. Wolffs

Manuscript in preparation 


\section{Abstract}

While antibiotic resistance is a major public health threat that we face worldwide, there are well recognised differences in the prevalence of resistant bacteria across geographic areas. Previous studies have shown that international travel constitutes a major factor for the spread of antibiotic resistance from endemic to low prevalence areas. Thus far however, no study has collected data on how rapid acquisitions of antimicrobial resistance genes (ARGs) or organisms occurs during travel.

Stool samples from 7 consenting Dutch subjects were collected prior and after travelling outside of Europe. Furthermore, faecal swabs from each available day during travel, as well as hand-skin swabs from the first few days of travel were collected and immediately stored in nucleic acid stabilizing buffer. Bacterial DNA was directly isolated from all collected samples and subsequently screened for the presence of several ARGs using qPCR.

We found that ARGs encoding for quinolone resistance ( $q n r B$ and $q n r S$ ) and for extended-spectrum beta-lactamases (b/a CTX-M $_{\text {M }}$ ) were acquired by participants who had visited South-Korea, India or the Filipinas. The median time to acquisition was 5 days, with the earliest detected ARG acquisition being on the 2 nd day of travel. Acquired genes could in some cases be detected up to 3 months after travel.

Our results show that the acquisition of ARG harbouring bacteria can occur within just several days, indicating that a relatively short exposure time to an environment with high rates of antibiotic resistance is sufficient to contribute to the spread of ARGs around the world. 


\section{Introduction}

The continuing global rise of antimicrobial resistance (AMR) is an increasing major public health threat. AMR limits clinical treatment options for bacterial infections, thereby reducing clinical efficacy and increasing mortality at a global scale. Despite the fact that AMR prevalence in the community is increasing in virtually all parts of the world, there are still major differences in the prevalence of certain antibiotic resistant bacteria between geographic areas [1]. For example, carriage rates of extended-spectrum beta-lactamase (ESBL) producing Enterobacteriaceae are much higher in Southeast Asia and the Eastern Mediterranean as compared to Europe and North America [2]. Similarly, carbapenemase producers are widespread in some areas, while they are very rare in other parts of the world [3,4].

Previous cohort studies have shown that human travel to areas with a high prevalence of $A M R$ contributes to the spread of antibiotic resistant bacteria or antibiotic resistance genes (ARGs) across geographic areas [5-19]. The acquisition of ARGs during travel may have several consequences. Firstly, exposure to or colonization with antibiotic resistant bacteria, such as ESBL-producing Enterobacteriaceae, can lead to difficult to treat infections [20-22]. Secondly, the import of ARGs from endemic areas to areas with a low prevalence of resistance could subsequently lead to further dissemination. This may occur through e.g. transmission to household members, but also through release of the bacteria or their genetic material into the environment, thereby enriching the local environmental resistome [23].

Previous studies all provide evidence that acquisition of resistant bacteria takes place during international travel, and some risk factors for acquisition have been identified, no data however is available about the actual dynamics of changes in the resistome during travel itself. In the current study, we therefore aimed to investigate the dynamics of the travellers' resistome by screening for several ARGs in the gut and skin microbiomes of travellers during the course of their travels. 


\section{Materials and Methods}

\section{Study population and sample collection}

In this study, a total of 6 healthy Dutch volunteers who were planning to travel outside of Europe and had not used antibiotics in the previous 3 months were recruited. The participants were asked to collect three types of samples before, during and after an international trip: faecal matter, faecal swabs and hand skin swabs. They were also asked to provide information on the trips such as dates and destinations as well as any use of antibiotics during the study period.

Faecal matter was collected before and at several time points after each trip. Faecal swabs were taken at the same time points as the faecal matter samples, as well as at each day of defecation day during travel. Hand swabs were taken from the palm and fingers of the dominant hand at any given point during the day, preferably consecutively during the first five days of travel. All swabs were immediately stored in DNA/RNA Shield (Zymo Research, Irvine, USA) to ensure the stability of the metagenome during unrefrigerated transport.

\section{Sample processing and DNA extraction}

The collected faecal samples were either immediately stored at $-20^{\circ} \mathrm{C}$ and shipped to the lab under refrigerated conditions, or were stored at $4^{\circ} \mathrm{C}$ for one day and then at $-20^{\circ} \mathrm{C}$ after being delivered to the lab the next day. The faecal and hand-skin swabs, suspended in DNA/RNA Shield solution as described above, were stored at ambient temperature during the participants' travels and then either directly submitted to DNA extraction in the lab or stored at $-20^{\circ} \mathrm{C}$ in the lab until DNA extraction. The sampling procedures within subjects were always the same. The extraction of DNA was performed as described previously [15]. Briefly, either $200 \mathrm{mg}$ of faeces, or $200 \mu \mathrm{l}$ of DNA/RNA Shield (in which the swabs were suspended) was added to a $2-\mathrm{mL}$ vial containing $0.5 \mathrm{~g}$ of $0.1 \mathrm{~mm}$ zirconia/silica beads (BioSpec, Bartlesville, OK, USA), 4 glass beads (3.0-3.5 mm)(BioSpec) and $1.2 \mathrm{ml}$ of lysis buffer from the PSP Spin Stool Kit (Stratec Molecular, Berlin, Germany). Samples were disrupted in a MagNA Lyser device (Roche, Basel, Switzerland) in three cycles of $1 \mathrm{~min}$. at a speed of $5500 \mathrm{rpm}$. Subsequently, DNA was isolated from the samples with the PSP Spin Stool Kit, according to the manufacturer's instructions. 


\section{Real time PCR assays}

Real-time PCR to detect antibiotic resistance genes was performed as described previously for $q n r A, q n r B$, $q n r S$, bla ${ }_{\text {СтX-M }}$ [15] and $m c r-1$ [16]. Amplification of carbapenemase encoding genes $b / a_{\mathrm{KPC}}, b / a_{\mathrm{NDM}}$ and $b / a_{\mathrm{OXA}-48}$ was performed in a 7900HT Fast Real-Time PCR System (Thermo Fisher Scientific, Waltham, MA, USA) in $25 \mu$ l volumes containing $12.5 \mu$ l ABsolute QPCR ROX Mix (Thermo Fisher Scientific), $5 \mu$ template DNA, and primer/probe mix as described earlier [24-26]. The cycling conditions were $15^{\prime}$ at $95^{\circ} \mathrm{C}$, followed by 45 cycles of $15^{\prime \prime}$ at $95^{\circ} \mathrm{C}$ and $60^{\prime \prime}$ at $60^{\circ} \mathrm{C}$.

For bla $a_{\mathrm{VIM}}$, primers GTCATGAAAGTGCGTGGAGA-3') (5'-CGTGATGGYGATGAGTTGCT-3' and 5'and a probe (FAM-5'GA[+T]TGARAAGC[+A]AATTGG[+A]CT-3'-BHQ1) were designed for this study to cover all 51 alleles currently reported in NCBI's GenBank, except for the divergent VIM-7 allele. Amplification was performed in a 7900HT Fast Real-Time PCR System in $25 \mu$ l volume containing $12.5 \mu$ ABsolute QPCR ROX Mix, $5 \mu$ lemplate DNA, $300 \mathrm{nM}$ of both bla $a_{\mathrm{VIM}}$ primers and $200 \mathrm{nM}$ of bla $\mathrm{VIM}_{\mathrm{VI}}$ probe. The cycling conditions were $15^{\prime}$ at $95^{\circ} \mathrm{C}$, followed by 45 cycles of $15^{\prime \prime}$ at $95^{\circ} \mathrm{C}$ and $60^{\prime \prime}$ at $60^{\circ} \mathrm{C}$. The amplification efficiency and detection limit of the bla $a_{\mathrm{VIM}}$ assay were determined by performing triplicate measurements of standard curves (series of 8 log dilutions) of a pGEM-T easy plasmid construct (Promega Corporation, Madison, WI, USA) harbouring the targeted bla $a_{\mathrm{VIM}}$ sequence, which was generated as described previously [16]. The efficiency was $98 \%$ with a detection limit of 5 gene copies per reaction.

To normalize for the different amounts of bacterial DNA in the samples a 500bp fragment 16S rDNA amplification was used. The 16S rDNA was amplified on a MyiQ ${ }^{\text {TM }}$ Single-Color Real-Time PCR Detection System (BioRad, Hercules, CA, USA) in $25 \mu$ l volume containing $12.5 \mu \mathrm{l}$ iQ $^{\text {TM }}$ SYBR $^{\circledR}$ Green Supermix (BioRad), $5 \mu \mathrm{l}$ template DNA and 300 nM of both forward (5'- CCTACGGGNGGCWGCAG -3') and reverse (5'- GACTACHVGGGTATCTAATCC -3') primers [27]. The cycling conditions were as follows: $3^{\prime}$ at $95^{\circ} \mathrm{C}$, followed by 35 cycles of $15^{\prime \prime}$ at $95^{\circ} \mathrm{C}, 20^{\prime \prime}$ at $55^{\circ} \mathrm{C}$ and $30^{\prime \prime}$ at $72^{\circ} \mathrm{C}$, followed by a melting curve analysis. The amplification efficiency was determined to be $103 \%$ by performing triplicate measurements of standard curves of a pGEM-T easy plasmid construct (Promega Corporation) harbouring targeted 16S rDNA sequence, which were generated as described previously [16]. 


\section{Results}

In total, we investigated 7 travelling individuals, 3 female and 4 male (Trip no. 1 and 4 were made by the same individual, see table 1) between 2013 to 2015 . The duration of travel ranged from 10 to 21 days, with a median of 14 days. All, except 1 traveller who visited Canada, travels were to countries in Asia (Table 1). Furthermore, trips \#1 and \#2 were made together by companions. None of the participants were hospitalized and they all reported that they did not use antibiotics during, or in the 3 months preceding travel.

Table 1: Characteristics of the study population

\begin{tabular}{llllll}
\hline Trip \# & Sex & Age & Destination & Date & Duration (days) \\
\hline 1 & M & 24 & South Korea & 2013 & 12 \\
2 & F & 24 & South Korea & 2013 & 12 \\
3 & M & 37 & India & 2014 & 21 \\
4 & M & 24 & India & 2014 & 10 \\
5 & F & 38 & China & 2015 & 21 \\
6 & F & 38 & Canada & 2015 & 14 \\
7 & M & 25 & Philippines & 2015 & 14 \\
\hline
\end{tabular}

For 6 out of the 7 travels, at least one of the ARGs screened for had been acquired. Overall, the acquisition time of an ARGs in the gut microbiota ranged from 2 to 13 days, with the median being 5 days.

Acquisition of bla $a_{\text {CTX-M }}$ genes was detected during 2 travels (Figure $1 \mathrm{~A}$ ), with its earliest acquisition detected on the $8^{\text {th }}$ day of the trip. For one of the travellers, the gene was still detectable 1 month after travel (last sampling time point for this traveller), whereas for the other traveller, the gene was only detectable on the first day after travel, but not after that. Hand skin swabs collected during trip \#4 were positive for bla $a_{\text {CTX-M }}$ on days 2 and 6 (Figure S1A), while the faecal samples collected during that trip remained negative.

While the qnrA gene was detected only once in a hand skin swab sample taken by the concerning traveller on the $2^{\text {nd }}$ day of trip \#7 (data not shown), the qnrB and qnrS genes were detected in 5 and 6 of the travellers respectively. Faecal samples of two participants already tested positive for the qnrB gene before 
travel, whereas the gene was for the first time detected during travel in 3 other participants (Figure 1B). Notably, the acquisition of this gene already occurred at the $2^{\text {nd }}$ day of travel for one participant. For one other traveller, $q n r B$ was detected in his faecal microbiome only at a single day during travel, but not for the remainder of the trip or after the trip, suggesting only transient carriage of the acquired gene. For the person that made trip \#3, hand skin swabs were found to be positive for $q n r B$ on days 2, 3 and 20 (Figure S1B), and the gene was also detected in the participant's faecal swabs from day 6 of travel onwards.

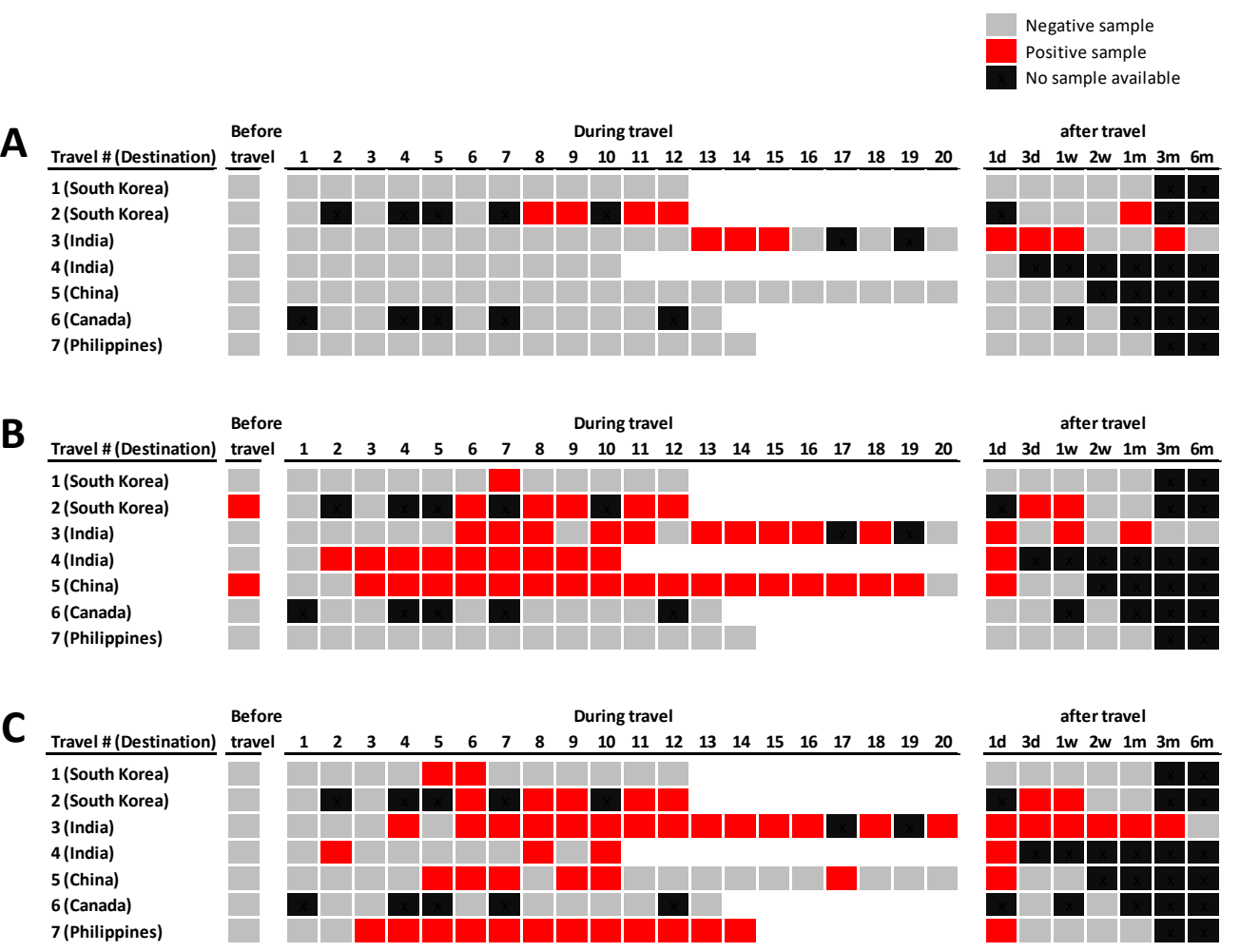

Figure 1. Presence of (A) $b / a_{\mathrm{CTX}-\mathrm{M}}$ (B) qnrB and (C) qnrS genes in faecal metagenomes before, during or after international travel. Grey squares represent samples which were negative, while red squares represent those which were positive. Black squares represent time points at which no sample was collected. $1 \mathrm{~d}$ : 1 day; $3 \mathrm{~d}$ : 3 days; 1 w: 1 week; 2 w: 2 weeks; 1m: 1 month; 3m; 3 months; $6 \mathrm{~m}$ : 6 months. 
None of the carbapenemases encoding genes $b / a_{\mathrm{KPC}}, b / a_{\mathrm{NDM}}, b / a_{\mathrm{OXA}-48}$ and $b / a_{\mathrm{VIM}}$, nor the plasmid mediated colistin resistance gene $m c r-1$ were detected in any of the samples.

For several travels, some intermittently negative samples were observed. I.e., the traveller's samples were positive for an ARGs for several consecutive days, with the exception of a few time points within that period, as is observed e.g. for the qnrB gene during trip \#3 (Figure 1B). Analysis of the DNA load of the samples by determining the $16 \mathrm{~S}$ rDNA concentration indicated that intermittent negative samples were in part due to a low DNA load in the samples, causing the ARG to drop below the detection limit, as illustrated in Figure 2.

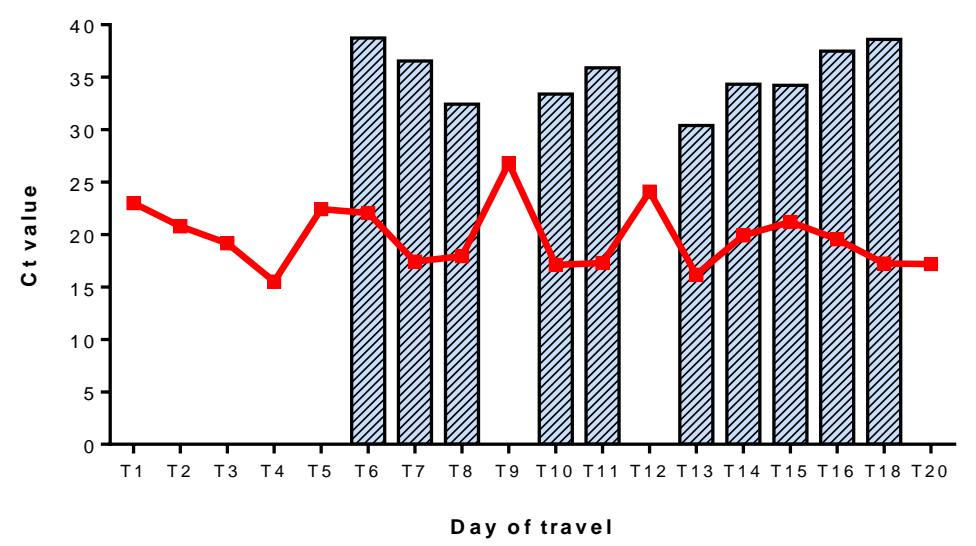

Figure 2. Analysis of the DNA load in samples which were intermittently negative for an ARG. DNA load of the samples was determined by the PCR Ct value obtained for $16 \mathrm{~S}$ rDNA. A higher $C t$ value represents a lower DNA load. In this example, samples which were intermittently negative for $q n r B$ showed a lower DNA load in the samples, suggesting this may have resulted in several samples reported to be false-negative for an ARG. 


\section{Discussion}

The results of this study show that the acquisition of ARG harbouring bacteria can occur within several days. If ARG acquisition can already be detected after two days of travel to an endemic country, then people could be at risk during short visits to other places with high rates of resistance, such as hospitals and farms. This could have implications for individuals at higher risk of infection, such as persons with an impaired immune functionality. Furthermore, the observation that such short exposure may be sufficient for the spread of ARGs from endemic into a low prevalence areas highlights the importance of travel in the dissemination of resistance elements around the world [23].

In all travels, except for the trip to Canada, at least one of the investigated ARGs was acquired. This indicates that acquisition of ARGs during travel is frequent. While our small study population prevents the conclusion of reliable prevalence data, these findings are in line with those determined in previous studies [28]. For example, we report the acquisition of qnrS during 6 out of the 7 trips. In a previous study, we showed a high acquisition rate of this ARG in travellers returning from Asia and Africa. Some studies from Asian countries have also reported a relatively high prevalence rate of qnr genes in bacterial isolates $[29,30]$ or faecal metagenomes [31]. The ESBL encoding bla $a_{\text {CTX-M }}$ genes were detected in samples from participants who had visited either India or South Korea. Previous studies have shown that up to $88 \%$ and $67 \%$ of travellers returning from southern Asia and other Asian regions respectively had acquired multidrug resistant Enterobacteriaceae, of which the majority harboured CTX-M genes [28]

The absence of carbapenemases encoding genes was not unexpected, as other travel-related cohort studies have found only sporadic acquisitions of these genes $[19,28]$. Also, the $m c r-1$ gene was not detected in any sample. While acquisition of this gene during travel has not been reported to be as high as for example $b / a_{\mathrm{CTX} M \mathrm{M}}$ or qnr genes, we and others have previously demonstrated the spread of this ARG by travellers $[6,16]$.

Interestingly, bla $a_{\mathrm{CTX}-\mathrm{M}}$ was detected on the hand skin swabs, but not in the faecal samples of one traveller who had visited India. The bla $a_{\text {CTX-M }}$ gene is known to be highly endemic in India, as shown by several studies investigating e.g. hospitalized patients [32,33], healthy individuals and environment [32], imported vegetables [34] or travellers who had visited the country [5, 9-11, 14, 18]. Thus, while acquisition in the gut microbiota was either not established or not detected, 
there was exposure to this traveller in particular, and most likely also to other travellers in general, highlighting the potential importance of personal (hand) hygiene in such high risk environments in order to prevent colonisation or further transmission.

In addition, for one participant, ARGs were detected during travel, but could not be detected at later time points of that trip or in the faecal sample collected upon returning home. This shows that while ARG acquisition in the gut microbiome may occur very rapidly, it may also be lost again before leaving the travel destination. As a result, a proportion of ARG acquisitions into the gut microbiome is not perceived when investigating only post-travel samples. Such short-term carriages do however pose a smaller risk, as the chance of infections with the resistant bacteria or onward transmission to e.g. household members or the home country is lower.

The duration which resistant bacteria or ARG persist in the microbiota after travel has been investigated by a few studies, which show that acquired multidrug resistant Enterobacteriaceae persisted in $6-28 \%$ of travellers up to six months upon travel return $[18,28]$. In the current study, the available data showed persistence ranging between 1 day and 3 months. More elaborate data about this, as well as on transmission rate to household members, is expected to be reported by the COMBAT study in the future [35].

One of the challenges in our study was the relatively low abundance of DNA acquired from some of the faecal swabs collected during travel, which naturally contained less faecal material than a stool sample collected before and after travel. This most likely led to the failure of detection of ARGs at certain days, while it was found to be present before and after that time point. Possibly, this may have also caused a slight underestimation of the speed of acquisition as determined in this study. With this in mind, future studies employing a similar type of sampling should be aware about collecting sufficient faecal material, especially considering the relatively low load of Enterobacteriaceae and their associated ARGs in faecal matter.

In conclusion, in this study we have shown that acquisition of ARGs occurs very rapidly during travel to countries with a high prevalence of antibiotic resistance. Some acquisitions were detectable only during travel itself and not after return, demonstrating a risk which usually remains undetected. That acquisition can occur so rapidly also highlights the risks for visitors to other types of high risk environments, e.g. healthcare settings, concerning antibiotic resistance. 


\section{Acknowledgements}

We would like to thank the participants for their dedication to the intensive sampling process of this study throughout their holidays. 


\section{References}

1. Hawkey PM, Jones AM. The changing epidemiology of resistance. J Antimicrob Chemother. 2009;64 Suppl 1:i3-10.

2. Woerther PL, Burdet C, Chachaty E, Andremont A. Trends in human fecal carriage of extended-spectrum beta-lactamases in the community: toward the globalization of CTX-M. Clin Microbiol Rev. 2013;26(4):744-58.

3. Doi Y, Paterson DL. Carbapenemase-producing Enterobacteriaceae. Semin Respir Crit Care Med. 2015;36(1):74-84.

4. Vlek AL, Frentz D, Haenen A, Bootsma HJ, Notermans DW, Frakking FN, et al. Detection and epidemiology of carbapenemase producing Enterobacteriaceae in the Netherlands in 2013-2014. Eur J Clin Microbiol Infect Dis. 2016.

5. Angelin M, Forsell J, Granlund M, Evengard B, Palmgren H, Johansson A. Risk factors for colonization with extended-spectrum beta-lactamase producing Enterobacteriaceae in healthcare students on clinical assignment abroad: A prospective study. Travel Med Infect Dis. 2015;13(3):223-9.

6. Arcilla MS, van Hattem JM, Matamoros S, Melles DC, Penders J, de Jong MD, et al. Dissemination of the mcr-1 colistin resistance gene. Lancet Infect Dis. 2016;16(2):147-9.

7. Kantele A, Laaveri T, Mero S, Vilkman K, Pakkanen SH, Ollgren J, et al. Antimicrobials increase travelers' risk of colonization by extended-spectrum betalactamaseproducing Enterobacteriaceae. Clin Infect Dis. 2015;60(6):837-46.

8. Kennedy K, Collignon P. Colonisation with Escherichia coli resistant to "critically important" antibiotics: a high risk for international travellers. Eur J Clin Microbiol Infect Dis. 2010;29(12):1501-6.

9. Kuenzli E, Jaeger VK, Frei R, Neumayr A, DeCrom S, Haller S, et al. High colonization rates of extended-spectrum beta-lactamase (ESBL)-producing Escherichia coli in Swiss travellers to South Asia- a prospective observational multicentre cohort study looking at epidemiology, microbiology and risk factors. BMC Infect Dis. 2014;14:528.

10. Lubbert C, Straube L, Stein C, Makarewicz O, Schubert S, Mossner J, et al. Colonization with extended-spectrum beta-lactamase-producing and carbapenemase-producing Enterobacteriaceae in international travelers returning to Germany. Int J Med Microbiol. 2015;305(1):148-56.

11. Ostholm-Balkhed A, Tarnberg M, Nilsson M, Nilsson LE, Hanberger $H$, Hallgren A, et al. Travel-associated faecal colonization with ESBL-producing Enterobacteriaceae: incidence and risk factors. J Antimicrob Chemother. 2013;68(9):2144-53.

12. Paltansing S, Vlot JA, Kraakman MEM, Mesman R, Bruijning ML, Bernards AT, et al. Extended-Spectrum $\beta$-Lactamase-producing Enterobacteriaceae among Travelers from the Netherlands. Emerg Infect Dis. 2013;19(8):1206-13.

13. Ruppe E, Armand-Lefevre L, Estellat C, Consigny PH, El Mniai A, Boussadia Y, et al. High Rate of Acquisition but Short Duration of Carriage of Multidrug-Resistant Enterobacteriaceae After Travel to the Tropics. Clin Infect Dis. 2015;61(4):593-600.

14. Tangden $T$, Cars $O$, Melhus A, Lowdin E. Foreign travel is a major risk factor for colonization with Escherichia coli producing CTX-M-type extended-spectrum betalactamases: a prospective study with Swedish volunteers. Antimicrob Agents Chemother. 2010;54(9):3564-8. 
15. von Wintersdorff CJ, Penders J, Stobberingh EE, Oude Lashof AM, Hoebe CJ, Savelkoul PH, et al. High rates of antimicrobial drug resistance gene acquisition after international travel, The Netherlands. Emerg Infect Dis. 2014;20(4):649-57.

16. von Wintersdorff CJ, Wolffs PF, van Niekerk JM, Beuken E, van Alphen LB, Stobberingh EE, et al. Detection of the plasmid-mediated colistin-resistance gene mcr-1 in faecal metagenomes of Dutch travellers. J Antimicrob Chemother. 2016;in press.

17. Weisenberg SA, Mediavilla JR, Chen L, Alexander EL, Rhee KY, Kreiswirth BN, et al. Extended spectrum beta-lactamase-producing Enterobacteriaceae in international travelers and non-travelers in New York City. PLoS ONE. 2012;7(9):e45141.

18. Barreto Miranda IDM, Ignatius RPDM, Pfuller RDM, Friedrich-Janicke BDM, Steiner FDM, Paland MDM, et al. High carriage rate of ESBL-producing Enterobacteriaceae at presentation and follow-up among travellers with gastrointestinal complaints returning from India and Southeast Asia. J Travel Med. 2016;23(2).

19. Reuland EA, Sonder GJ, Stolte I, AI Naiemi N, Koek A, Linde IB, et al. Travel to Asia and traveller's diarrhoea with antibiotic treatment are independent risk factors for acquiring ciprofloxacin-resistant and extended spectrum betalactamase-producing Enterobacteriaceae - a prospective cohort study. Clin Microbiol Infect. 2016.

20. Epelboin L, Robert J, Tsyrina-Kouyoumdjian E, Laouira S, Meyssonnier V, Caumes E. High Rate of Multidrug-Resistant Gram-Negative Bacilli Carriage and Infection in Hospitalized Returning Travelers: A Cross-Sectional Cohort Study. J Travel Med. 2015;22(5):292-9.

21. Freeman JT, McBride SJ, Heffernan H, Bathgate T, Pope C, Ellis-Pegler RB. Community-onset genitourinary tract infection due to CTX-M-15-Producing Escherichia coli among travelers to the Indian subcontinent in New Zealand. Clin Infect Dis. 2008;47(5):689-92.

22. Soraas A, Sundsfjord A, Sandven I, Brunborg C, Jenum PA. Risk factors for community-acquired urinary tract infections caused by ESBL-producing enterobacteriaceae--a case-control study in a low prevalence country. PLoS ONE. 2013;8(7):e69581.

23. von Wintersdorff CJ, Penders J, van Niekerk JM, Mills ND, Majumder S, van Alphen LB, et al. Dissemination of Antimicrobial Resistance in Microbial Ecosystems through Horizontal Gene Transfer. Front Microbiol. 2016;7:173.

24. Hindiyeh M, Smollen G, Grossman Z, Ram D, Davidson Y, Mileguir F, et al. Rapid detection of blaKPC carbapenemase genes by real-time PCR. J Clin Microbiol. 2008;46(9):2879-83.

25. Naas T, Cotellon G, Ergani A, Nordmann P. Real-time PCR for detection of blaOXA-48 genes from stools. J Antimicrob Chemother. 2013;68(1):101-4.

26. Naas T, Ergani A, Carrer A, Nordmann P. Real-time PCR for detection of NDM-1 carbapenemase genes from spiked stool samples. Antimicrob Agents Chemother. 2011;55(9):4038-43.

27. Klindworth A, Pruesse E, Schweer T, Peplies J, Quast C, Horn M, et al. Evaluation of general 16S ribosomal RNA gene PCR primers for classical and next-generation sequencing-based diversity studies. Nucleic Acids Res. 2013;41(1):e1. 
28. Hassing RJ, Alsma J, Arcilla MS, van Genderen PJ, Stricker BH, Verbon A. International travel and acquisition of multidrug-resistant Enterobacteriaceae: a systematic review. Euro Surveill. 2015;20(47).

29. Jeong HS, Bae IK, Shin JH, Kim SH, Chang CL, Jeong J, et al. Fecal colonization of Enterobacteriaceae carrying plasmid-mediated quinolone resistance determinants in Korea. Microb Drug Resist. 2011;17(4):507-12.

30. Jiang $X$, Li J, Zhang Y, Yan H, Wang Y, Shi L, et al. Detection of plasmid-mediated quinolone resistance determinants and qurS expression in Enterobacteriaceae clinical isolates. J Infect Dev Ctries. 2014;8(12):1625-9.

31. Vien le TM, Minh NN, Thuong TC, Khuong HD, Nga TV, Thompson C, et al. The coselection of fluoroquinolone resistance genes in the gut flora of Vietnamese children. PLoS ONE. 2012;7(8):e42919.

32. George EA, Sankar S, Jesudasan MV, Sudandiradoss C, Nandagopal B. Molecular characterization of CTX-M type Extended Spectrum Beta Lactamase producing E. coli isolated from humans and the environment. Indian J Med Microbiol. 2015;33 Suppl:73-9.

33. Sankar S, Narayanan H, Kuppanan S, Nandagopal B. Frequency of extended-spectrum beta-lactamase (ESBL)-producing Gram-negative bacilli in a 200-bed multi-specialty hospital in Vellore district, Tamil Nadu, India. Infection. 2012;40(4):425-9.

34. Zurfluh K, Nuesch-Inderbinen M, Morach $M$, Zihler Berner A, Hachler H, Stephan R. Extended-spectrum-beta-lactamase-producing Enterobacteriaceae isolated from vegetables imported from the Dominican Republic, India, Thailand, and Vietnam. Appl Environ Microbiol. 2015;81(9):3115-20.

35. Arcilla MS, van Hattem JM, Bootsma MC, van Genderen PJ, Goorhuis A, Schultsz C, et al. The Carriage Of Multiresistant Bacteria After Travel (COMBAT) prospective cohort study: methodology and design. BMC Public Health. 2014;14:410. 


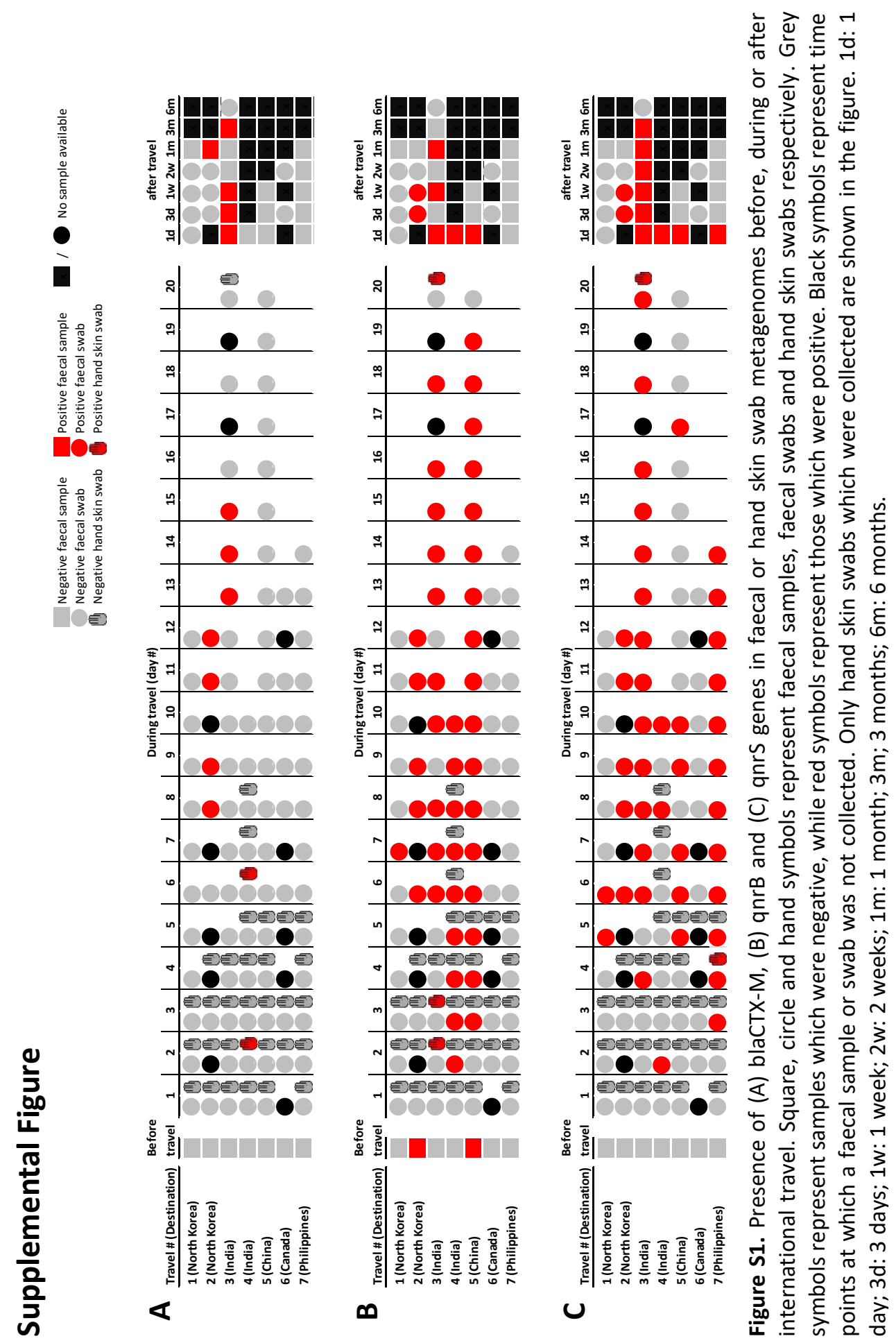




\section{Chapter 6}

Detection of the plasmid-mediated colistin-resistance gene $\mathrm{mcr}-1$ in faecal metagenomes of Dutch travellers

Christian J.H. von Wintersdorff, Petra F.G. Wolffs, Julius M. van Niekerk, Erik Beuken, Lieke B. van Alphen, Ellen E. Stobberingh, Astrid M.L. Oude Lashof, Christian J.P.A. Hoebe, Paul H. M. Savelkoul \& John Penders

Essentially described in J Antimicrob Chemother. 2016 Aug 23. pii: dkw328 


\section{Abstract}

\section{Background:}

Recently, the first plasmid-mediated colistin resistance gene, $m c r-1$, was reported. Colistin is increasingly used as a last resort antibiotic for the treatment of infections with carbapenem resistant bacteria, which have been rapidly disseminating worldwide in recent years.

\section{Objectives:}

The reported carriage rate of mcr-1 in humans remains sporadic thus far, except for those reported in Chinese populations. We aimed to determine its presence in the faecal metagenomes of healthy Dutch travellers between 2010 and 2012.

\section{Methods:}

Faecal metagenomic DNA of pre- and post-travel samples from 122 healthy Dutch long-distance travellers was screened for the presence of mcr-1 using a TaqMan real-time PCR assay which was designed and validated in this study. All positive samples were confirmed by sequencing of the amplicons.

\section{Results:}

The mcr-1 gene was detected in $6(4.9 \%, 95 \% \mathrm{Cl} 2.1-10.5)$ out of 122 healthy Dutch long-distance travellers after they had visited destinations in South(east) Asia or southern Africa between 2011 and 2012. One of these participant was already found to be positive before travel.

\section{Conclusions:}

Our study highlights the potential of PCR-based targeted metagenomics as an unbiased and sensitive method to screen for the carriage of the mcr-1 gene, and suggests that $m c r-1$ is widespread in various parts of the world. The observation that one participant was found to be positive before travel suggests that $\mathrm{mcr}-1$ may already have disseminated to the microbiomes of Dutch residents at a low prevalence, warranting a more extensive investigation of its prevalence in the general population and possible sources. 


\section{Introduction}

The first plasmid mediated colistin resistance gene, mcr-1, was recently reported by Liu and colleagues [1]. Before their findings, colistin resistance was considered to arise due to chromosomal mutations [2], and therefore believed to have a limited dissemination, restricted to clonal transmission. Colistin is increasingly used as a last resort antibiotic for the treatment of infections with carbapenem resistant bacteria, which have been rapidly disseminating worldwide in recent years [3]. Thus, the finding of plasmid-mediated colistin resistance has rightfully drawn renewed attention to colistin resistance. Considering the successful dissemination of genes encoding extended-spectrum beta-lactamases (ESBLs), carbapenemases and other resistance mechanisms by horizontal gene transfer [4], the mobile colistin resistance gene $m c r-1$, which could facilitate a similar successful dissemination for resistance to colistin, may have major implications for public health.

Liu et al. described a high prevalence of $m c r-1$ in E. coli isolates from retail meat (15\%), pigs at slaughter (21\%) and a relatively lower prevalence in $E$. coli and K. pneumoniae isolates from human patients ( $1.4 \%$ and $0.7 \%$ respectively), raising the concern whether this gene had spread outside of China [1]. Shortly after their report, several other studies have investigated and confirmed the occurrence of $m c r-1$ in various parts of the world, including several parts of Asia [5-10], as well as Europe [11-22] and Africa [23, 24].

While the rates of $\mathrm{mcr}-1$ positive strains isolated from animals or food was quite high according to some of these studies $[5,24]$, the reported carriage rate in humans thus far remains sporadic except for those reported in Chinese populations [25].

The studies performed thus far have focused on either detecting mcr-1 in existing collections of cultured isolates, or by mining metagenomic sequencing data. As these existing collections were mostly restricted to specific microorganisms, resistance profiles (e.g. ESBLs) or patient populations, and sensitivity of sequence-based metagenomics is relatively low, we hypothesized that the prevalence of mcr-1 as reported in these studies might be an underestimation of the human carriage rates in the community.

In the current study, we applied a PCR-based targeted metagenomic approach to screen for the presence of the mcr-1 gene in the faecal metagenomes of healthy Dutch travellers between 2010 and 2012. In addition, from faecal samples 
screened positive for the presence of the mcr-1 gene by this method, isolates harbouring the mcr-1 genes were cultured in order to define the characteristics of those strains.

\section{Methods}

\section{Study population}

This study comprised 122 healthy Dutch long-distance travellers, who had been recruited in a prospective travel cohort study as described previously [26]. Shortly, participants were recruited between November 2010 and August 2012 through travel clinics (EASE Travel Clinic \& Health Support, www.easetravelclinic.nl/en/) located in the southern part of the Netherlands. Consenting participants were asked to collect a faecal sample before and on average 1 week after travel, along with records of the duration and destination of their travel, illnesses or complaints during travel and antimicrobial drug use within the 3 months preceding post-travel sampling.

\section{Faecal processing and metagenomic DNA extraction}

Processing and DNA extraction of faecal samples was described previously [26]. In brief, faecal samples were 10-fold diluted in peptone/water (Oxoid, Basingstoke, United Kingdom) containing 20\% (vol/vol) glycerol (Merck, Darmstadt, Germany), homogenized by vortexing and stored at $-20^{\circ} \mathrm{C}$ until further analysis. For the extraction of metagenomic DNA, $200 \mu \mathrm{l}$ of diluted faeces was added to a 2-mL vial containing $0.5 \mathrm{~g}$ of $0.1 \mathrm{~mm}$ zirconia/silica beads (BioSpec, Bartlesville, OK, USA), 4 glass beads $(3.0-3.5 \mathrm{~mm})($ BioSpec) and $1.2 \mathrm{ml}$ of lysis buffer from the PSP Spin Stool Kit (Stratec Molecular, Berlin, Germany). Samples were disrupted in a Magna Lyser device (Roche, Basel, Switzerland) in three cycles of $1 \mathrm{~min}$. at a speed of $5500 \mathrm{rpm}$. Subsequently, metagenomic DNA was isolated from the samples with the PSP Spin Stool Kit, according to the manufacturer's instructions. 


\section{Molecular detection of antibiotic resistance genes}

In order to obtain increased assay specificity on metagenomic samples, a TaqMan qPCR assay was developed and validated in this study. In addition to using the primers described by Liu et al [1] (forward: 5'-CGGTCAGTCCGTTTGTTC3', reverse: 5'-CTTGGTCGGTCTGTAGGG-3'), IDT's PrimerQuest Tool (idtdna.com) was used to design a probe (5'-TTGACCGCGACCGCCAATCTTA-3') which was labelled with a FAM reporter and a Black Hole Quencher (BHQ1) (Sigma-Aldrich, St. Louis, MO, USA). Amplifications were performed on a 7900HT Fast Real-Time PCR System (Thermo Fisher Scientific, Waltham, MA, USA) in $25 \mu$ l reactions containing $12.5 \mu \mathrm{l}$ ABsolute QPCR ROX Mix (Thermo Fisher Scientific), $5 \mu \mathrm{l}$ template DNA, $300 \mathrm{nM}$ of both the forward and reverse primer and $200 \mathrm{nM}$ of probe. Thermal cycling consisted of 15 minutes at $95^{\circ} \mathrm{C}$, followed by 45 cycles of 15 seconds at $95^{\circ} \mathrm{C}$ and 1 minute at $60^{\circ} \mathrm{C}$. In order to assess efficiency of the assay, a control plasmid was created by cloning the corresponding PCR amplicon into a PGEM-T easy vector (Promega Corporation, Madison, WI, USA) according to the manufacturer's protocol. Plasmids were isolated using standard alkaline lysis, after which these products were subjected to gel-electrophoresis, followed by excision of the target plasmids from the electrophoresis gel and purified using a GenElute $^{\mathrm{TM}}$ Gel Extraction Kit (Sigma-Aldrich). Finally, quantification was performed with a Quant-i $\mathrm{T}^{\mathrm{TM}}$ PicoGreen $^{\circledR}$ dsDNA Assay Kit (Thermo Fisher Scientific). Standard curves were then generated by triplicate measurements of serial dilutions of the control plasmid, as well as triplicate measurements of serial dilutions of the control plasmid spiked into 3 different (faecal) metagenomic DNA samples.

All samples indicated as positive by qPCR were confirmed by sequencing using the PCR primers and a BigDye Terminator v1.1 Cycle Sequencing Kit (Thermo Fisher Scientific). Sequencing data were obtained on an ABI 3730 DNA Analyzer (Thermo Fisher Scientific) and were analysed by using NCBI's Basic Local Alignment Search Tool (BLAST). Real-time PCR to detect bla ${ }_{\mathrm{CTX}-\mathrm{M}}$, $q n r A, q n r B$ and qnrS genes in $m c r-1$ harbouring isolates obtained in this study was performed as described previously [26]. 


\section{Microbiological methods}

Faecal samples (diluted as described above), which tested positive for the $\mathrm{mcr}$ 1 gene were streaked onto lysogenic broth (LB) agar plates containing colistin (2 $\mathrm{mg} / \mathrm{L}$ ) and vancomycin $(50 \mathrm{mg} / \mathrm{L})$ and incubated overnight at $37^{\circ} \mathrm{C}$ in order to obtain colistin resistant isolates. Resulting colonies were visually inspected and Gram-negative suspected colonies were subsequently cultured onto new LB agar plates containing colistin and vancomycin. Once the cultures were visually confirmed to be pure and resistant to colistin, they were streaked onto blood agar plates (Becton-Dickinson, Franklin Lakes, NJ, USA) for identification by MALDI-TOF (bioMérieux, Marcy l'Etoile, France) and antibiotic susceptibility testing (AST) using the BD Phoenix Automated Microbiology System (Becton-Dickinson) and Etest for colistin (bioMérieux); results were interpreted according to the European Committee on Antimicrobial Susceptibility Testing (EUCAST) [27]. Additionally, 1 colony was suspended into $500 \mu \mathrm{l}$ of sterile $\mathrm{ddH}_{2} \mathrm{O}$, lysed by heating to $95^{\circ} \mathrm{C}$ for 10 minutes and centrifuged at $16,000 \mathrm{~g}$ for 1 minute. The resulting supernatants were used for molecular confirmation of resistance genes.

Faecal samples which did not yield colistin resistant bacteria with the above described approach were enriched by culturing in brain heart infusion (BHI) broth supplemented with vancomycin $(50 \mathrm{mg} / \mathrm{L})$ and incubated overnight at $37^{\circ} \mathrm{C}$ while shaking. Subsequently, these cultures were streaked onto $\mathrm{BHI}$ agar plates containing colistin $(2 \mathrm{mg} / \mathrm{L})$ and vancomycin $(50 \mathrm{mg} / \mathrm{L})$, followed by selection of suspected colistin resistant, Gram-negative colonies as described above.

\section{Molecular typing}

PFGE was performed on colistin resistant E. coli isolates essentially according to the rapid procedure described previously [28]. After 15 minutes of preincubation in $200 \mu \mathrm{l}$ of the restriction enzyme buffer, supplemented with 100 $\mu \mathrm{g} / \mathrm{ml} \mathrm{BSA}, \sim 2 \times 5 \mathrm{~mm}$ thick slices of each plug were incubated at $37^{\circ} \mathrm{C}$ for $3 \mathrm{~h}$ with 30 Units of Xbal enzyme in $100 \mu \mathrm{l}$ of the restriction enzyme buffer $+100 \mu \mathrm{g} / \mathrm{ml}$ BSA. Fragments were separated on a $1 \%$ SeaKem Gold agarose gel for $16 \mathrm{~h}$. Salmonella serotype Braenderup H9812 strain (ATCC strain BAA-664) was included as reference strain. The resulting gel was analysed with BioNumerics v7.5 and according to the Tenover criteria [29]. MLST was performed according to Wirth et al [30]. 


\section{Results}

\section{Validation of a TaqMan qPCR assay for metagenomic screening}

We developed a $309 \mathrm{bp}$ real-time PCR assay using a Taqman probe. The primers and probe were matched against all mcr-1 entries in GenBank. At this time however, no variations in nucleotide sequences have been documented. In order to assess the specificity of the designed assay, all metagenomic DNA isolations of faecal samples (122 pre- and 122 post-travel) were analysed, resulting in 0 false positive signals. The assay was linear over 8 log dilutions of a control plasmid (Ct-value range: 10.7-33.5, max. variation between replicates 0.42 Ct, slope: -3.378 , R2: 0.999), with an efficiency of 98\% (Figure 1). While concentrations of $\sim 5$ plasmid copies per reaction were no longer within the linear reach and showed greater variation between replicates (Ct-value 36.4-37.7), they were nonetheless reproducibly detectable. Measuring log dilutions of the control plasmid spiked into DNA isolated from faecal samples yielded a similar efficiency (slope $=-3.341, R^{2}=0.999$ ) and sensitivity (data not shown).

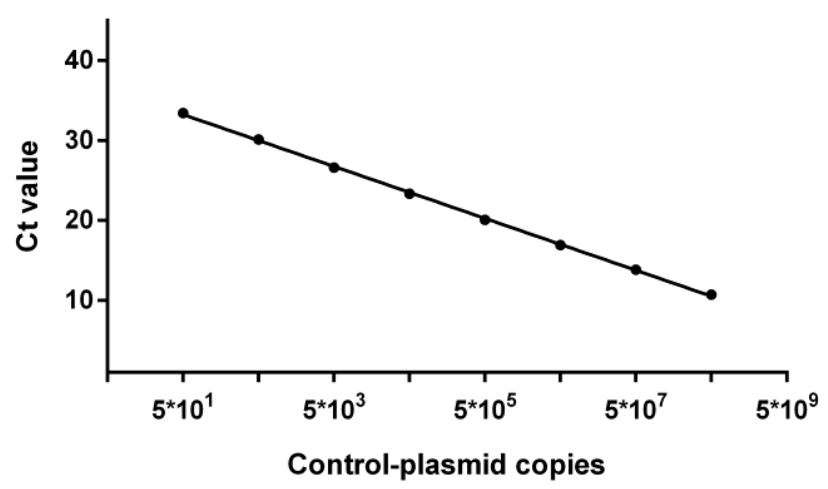

Figure 1: Standard curve of the mcr-1 TaqMan qPCR assay. Generated using serial (10fold) dilutions of recombinant plasmid DNA containing the targeted mcr-1 sequence. The average plus error bars (SD) of triplicate measurements of $\mathrm{Ct}$ values for each dilution are plotted against the number of plasmid copies per reaction. The slope of the standard curve was -3.378 with an $R^{2}$ of 0.999 . 


\section{High prevalence of $\mathbf{m c r}-\mathbf{1}$ in human faecal metagenomes}

Screening of the faecal metagenomes of 122 travellers before and after travel, yielded 7 samples positive for $m c r-1$ in total according to qPCR (Ct-value range: 24.1-40.2). Positive samples were all confirmed by sequencing, showing high specificity of the PCR assay (no false-positives were observed). For one participant, the $\mathrm{mcr}-1$ gene was detected in both the pre- and post-travel sample, whereas for 5 other participants only the post-travel sample was found to be positive, reflecting a post-travel prevalence of $4.9 \%(95 \% \mathrm{Cl} 0.021-0.105)$ and acquisition rate of $4.1 \%(95 \% \mathrm{Cl} 0.015-0.096)$. Travellers with suggested $\mathrm{mcr}-1$ acquisition visited destinations in South(east) Asia or southern Africa, specified in more detail in Table 1. Half of the participants who were positive for mcr-1 after travel had used antibiotics in the three months preceding post-travel sampling (Table 1), as compared to $9.5 \%$ of non-positive participants $(p<0.05)$.

Table 1: Characteristics of participants positive for mcr-1 carriage and antibiotic resistance genes (ARGs) detected in faecal metagenomes of 122 Dutch international travellers.

\begin{tabular}{|c|c|c|c|c|c|c|c|c|}
\hline $\begin{array}{l}\text { Participant } \\
\text { Nr. }\end{array}$ & Age & Sex & $\begin{array}{l}\text { Travel } \\
\text { duration } \\
\text { (days) }\end{array}$ & $\begin{array}{l}\text { AB } 3 \text { months } \\
\text { preceding } \\
\text { post-travel } \\
\text { sampling }\end{array}$ & Destination & $\begin{array}{l}\text { Date of } \\
\text { return }\end{array}$ & $\begin{array}{l}\text { ARGs in faecal } \\
\text { metagenome } \\
\text { pre-travel }\end{array}$ & $\begin{array}{l}\text { ARGs in faecal } \\
\text { metagenome } \\
\text { post-travel }\end{array}$ \\
\hline 1 & 55 & $M$ & 5 & Minocycline & Thailand & $\begin{array}{l}\text { May } \\
2011\end{array}$ & - & mcr-1, qnrs \\
\hline 2 & 69 & $M$ & 21 & - & Vietnam & $\begin{array}{l}\text { March } \\
2011\end{array}$ & qnrB & $\begin{array}{l}\text { mcr-1, CTX- } \\
M-2^{a}, \quad \text { CTX-M- } \\
9^{a}, \quad \text { qnrA, } \\
\text { qnrB, qnrS }\end{array}$ \\
\hline 3 & 24 & $\mathrm{~F}$ & 18 & - & Indonesia & $\begin{array}{l}\text { June } \\
2011\end{array}$ & - & mcr-1, qnrs \\
\hline 4 & 26 & $\mathrm{~F}$ & 21 & - & Tanzania & $\begin{array}{l}\text { June } \\
2011\end{array}$ & - & mcr-1, qnrs \\
\hline 5 & 40 & $\mathrm{~F}$ & 35 & $\begin{array}{l}\text { Trimethoprim } \\
\text { - } \\
\text { sulfamethoxa } \\
\text { zole }\end{array}$ & $\begin{array}{l}\text { Thailand \& } \\
\text { Vietnam }\end{array}$ & $\begin{array}{l}\text { Januari } \\
2012\end{array}$ & - & $\begin{array}{l}\text { mcr-1, qnrB, } \\
\text { qnrs }\end{array}$ \\
\hline 6 & 46 & $\mathrm{~F}$ & 10 & Azithromycin & India & $\begin{array}{l}\text { May } \\
2012\end{array}$ & $\mathrm{mcr}-1$, qnrB & $\begin{array}{l}\text { mcr-1, qnrB, } \\
\text { qnrs }\end{array}$ \\
\hline
\end{tabular}

$A B$, Antibiotic.

${ }^{a}$ CTX-M phylogenetic group as determined by $q P C R$. 


\section{Characteristics of the $\mathbf{m c r}-1$ harbouring strains}

The 7 faecal samples of participants which tested positive for mcr-1 with the targeted metagenomic approach were cultured in order to obtain colistin resistant Gram-negative bacteria. Three $m c r-1$ harbouring, colistin resistant $E$. coli isolates were obtained, which are specified in Table 2. Although 2 of these isolates were obtained from participant \#6 (one before travel; isolate 6T0, and one after travel; isolate 6T1), these strains were distinct as determined by PFGE (Figure 2) and MLST (Table 2) and moreover showed different AST profiles (Table 2). Considering the acquisition of other resistance genes in the faecal microbiomes mentioned in Table 1 , the isolated $m c r-1$ positive strains were also tested for the presence of $b / a_{\text {СTX-M }}, q n r A, q n r B$ and $q n r S$ genes, but were negative.

Table 2: MLST and antibiotic susceptibility testing profiles of $m c r-1$ harbouring $E$. coli isolated from Dutch human faecal samples.

\begin{tabular}{|c|c|c|c|c|c|c|}
\hline Isolate ID: & \multirow{2}{*}{\multicolumn{2}{|c|}{$\frac{2 \mathrm{~T} 1}{\mathrm{ST} 1011}$}} & \multirow{2}{*}{\multicolumn{2}{|c|}{$\begin{array}{c}6 \text { TO } \\
\text { ST } 744\end{array}$}} & \multirow{2}{*}{\multicolumn{2}{|c|}{$\begin{array}{c}\text { 6T1 } \\
\text { ST } 80\end{array}$}} \\
\hline MLST: & & & & & & \\
\hline & $\mathrm{MIC}(\mathrm{mg} / \mathrm{L})$ & $(S / R)^{a}$ & $\mathrm{MIC}(\mathrm{mg} / \mathrm{L})$ & (S/R) & $\mathrm{MIC}(\mathrm{mg} / \mathrm{L})$ & (S/R) \\
\hline Amikacin & $<=4$ & $(\mathrm{~S})$ & $<=3$ & $(\mathrm{~S})$ & $<=4$ & (S) \\
\hline Amoxicillin-Clavulanate & $32 / 2$ & (R) & $4 / 2$ & $(S)$ & $4 / 2$ & (S) \\
\hline Ampicillin & $>8$ & (R) & $>8$ & (R) & $<=2$ & (S) \\
\hline Cefepime & $<=1$ & (S) & $<=1$ & $(\mathrm{~S})$ & $<=1$ & (S) \\
\hline Cefoxitin & $<=4$ & $(\mathrm{~S})$ & $<=4$ & $(S)$ & $<=4$ & (S) \\
\hline Ceftazidime & $<=1$ & $(\mathrm{~S})$ & $<=1$ & $(S)$ & $<=1$ & (S) \\
\hline Ceftriaxone & $<=1$ & (S) & $<=1$ & $(\mathrm{~S})$ & $<=1$ & (S) \\
\hline Cefuroxime & 4 & (S) & 4 & (S) & $<=2$ & (S) \\
\hline Ciprofloxacin & $>1$ & (R) & $>1$ & (R) & $<=0.25$ & (S) \\
\hline Colistin $^{\mathrm{b}}$ & 3 & (R) & 3 & (R) & 3 & (R) \\
\hline Ertapenem & $<=0.25$ & (S) & $<=0.25$ & $(S)$ & $<=0.25$ & (S) \\
\hline Gentamicin & $<=1$ & $(\mathrm{~S})$ & $<=1$ & $(\mathrm{~S})$ & $<=1$ & (S) \\
\hline Imipenem & $<=0.25$ & $(\mathrm{~S})$ & $<=0.25$ & $(\mathrm{~S})$ & $<=0.25$ & (S) \\
\hline Levofloxacin & $>2$ & (R) & $>2$ & (R) & $<=0.5$ & (S) \\
\hline Meropenem & $<=0.125$ & $(\mathrm{~S})$ & $<=0.125$ & $(\mathrm{~S})$ & $<=0.25$ & (S) \\
\hline Piperacillin & $>16$ & (R) & $>16$ & (R) & $<=4$ & (S) \\
\hline Piperacillin-Tazobactam & $<=4 / 4$ & $(\mathrm{~S})$ & $<=4 / 4$ & $(S)$ & $<=4 / 4$ & (S) \\
\hline Temocillin & 16 & $(-)$ & $<=4$ & $(-)$ & $<=4$ & $(-)$ \\
\hline Tigecycline & $<=0.5$ & $(\mathrm{~S})$ & $<=0.5$ & $(\mathrm{~S})$ & $<=0.5$ & (S) \\
\hline Tobramycin & 2 & (S) & $<=1$ & $(\mathrm{~S})$ & $<=1$ & (S) \\
\hline Trimethoprim-Sulfamethoxazole & $>4 / 76$ & $(\mathrm{R})$ & $>4 / 76$ & $(\mathrm{R})$ & $<=1 / 19$ & $(S)$ \\
\hline
\end{tabular}

MIC, Minimal Inhibitory Concentration; (R), resistant; (S), susceptible; (-), no breakpoint available. MICs above the breakpoint $(\mathrm{R})$ are indicated in bold.

anterpretation according to EUCAST clinical breakpoints.

${ }^{\mathrm{b}}$ As determined by Etest. 
PFGE

PFGE

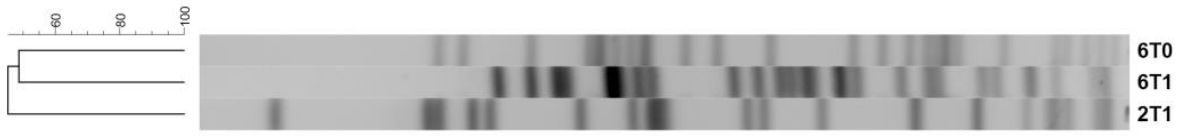

Figure 2: Pulsed-field gel electrophoresis of the three $m c r-1$ harbouring $E$. coli isolated from Dutch human faecal samples. Genomes of all three strains, restricted with Xbal, have a clear distinct PFGE band-pattern, showing that the two isolates acquired from the pre- (isolate 6T0) and post-travel (isolate 6T1) faecal sample of the same participant are both unique strains.

\section{Discussion}

The first plasmid-mediated colistin resistance gene, $m c r-1$, has only recently been described. As such, information on the extent to which this gene has disseminated globally is still limited. Thus far, the reported carriage rate in humans in Europe remains sporadic [25]. In our study, we report the occurrence of mcr-1 in the faecal microbiota of Dutch international travellers using a targeted, PCR-based metagenomic approach. Bontron et al. previously described a SYBR Green-based real-time PCR to overcome false-positive signals, which were observed with earlier published primers [31]. However, since metagenomic DNA samples are more prone to induce unspecific amplification due to the diversity of DNA templates present compared to e.g. DNA isolated from bacterial isolates, we opted for the addition of a TaqMan probe in our assay. The designed TaqMan assay was shown to be both specific and sensitive when used on isolated as well as on metagenomic samples.

Bacteria harbouring mcr-1 could be cultured from some, but not all investigated faecal samples that tested positive for this gene by qPCR. Likely, the (viable) bacterial load in the samples was too low or negatively affected by storage, as there was also an absence of growth of any other colistin resistant Gram-negative bacteria. Alternatively, the $m c r-1$ genes could be non-functional, non-expressed or originate from organisms not readily cultivatable with the currently used methods.

This study therefore shows a relatively high post-travel prevalence $(4.9 \%)$ of mcr-1 in the microbiota of travellers. The pre-travel prevalence $(0.8 \%)$ was much 
lower indicating that the $m c r-1$ carriage rate in the general Dutch population is low, which is in line with the recently reported absence of mcr-1 in a large collection (2275 isolates) of ESBL-producing Enterobacteriaceae from hospitalised patients, clinical cultures and outbreaks in healthcare settings in The Netherlands [32]. However, the high acquisition rate suggests that this mobile gene has already disseminated at high rates in certain parts of the world, and travel to such high-risk areas is a risk factor for its acquisition and further dissemination.

With regards to this, Arcilla and colleagues previously reported that $6(<1 \%)$ out of 633 ESBL-producing Enterobacteriaceae which were acquired by Dutch international travellers were positive for mcr-1 [33]. In our study, we did not select for travel-associated ESBL-producing isolates, but rather screened all faecal metagenomes, which most likely accounts for the higher acquisition rate. As such, it would be interesting to also apply a targeted metagenomic approach to study populations of such a magnitude.

Many studies on mcr-1 have investigated collections of ESBL producing Enterobacteriaceae, and it has been reported that $\mathrm{mcr}-1$ positive isolates often carry multiple resistance genes, including genes encoding for ESBLs [25]. For this reason, we investigated the antibiotic resistance profiles of the three isolates obtained from our study population. These were all determined to be non-ESBLproducers however. Notably, one isolate (6T1) was susceptible to all tested antibiotics other than colistin. To this end, there is a need for studies without selections based on resistance profiles to more clearly define this relationship.

While mcr-1 was detected in an E. coli isolate from chicken in China dating back to the 1980s [34], its earliest known occurrence in human samples was reported to be from somewhere before 2010 in China [25], and from 2011 in Europe (The Netherlands) [35]. Arcilla et al. previously reported that Dutch international travellers had acquired mcr-1 positive ESBL strains between 2012 or 2013 [33], demonstrating the dissemination of $\mathrm{mcr}-1$ by travel. The results in our study confirm those findings. Antibiotic use in the three months prior to posttravel sample collection was found to be a risk factor in our study. This is in line with previous reports that identified antibiotic use as a risk factor for the acquisition of ESBL-producing Enterobacteriaceae during travel [36]. Additionally, we report that one Dutch citizen carried an mcr-1 positive isolate (6T0) early in 2012, prior to traveling. This indicates that $m c r-1$ may already be established in the microbiomes of Dutch residents at a low prevalence since that time and 
possibly earlier. We can however not rule out that carriage was due to recent travel, since travel history prior to enrolment in this study was unknown.

In conclusion, we report a relatively high $\mathrm{mcr}-1$ prevalence in microbiomes of Dutch residents after international travel, highlighting the potential of PCR-based targeted metagenomics as an unbiased and sensitive method to screen for the carriage of $m c r-1$. The high acquisition rates show that travel contributes to the dissemination of mcr-1. Isolates obtained in this study were all non-ESBLproducers and one was even susceptible to all antibiotics except colistin. This suggest that it would be of interest for further studies into the occurrence of $\mathrm{mcr}$ 1 to not only investigate bacterial isolates with specific resistance profiles. Furthermore, that one participant was positive for $\mathrm{mcr}-1$ before travel indicates that the gene may already be present in the microbiomes of Dutch residents at a low prevalence, warranting a more extensive investigation of its prevalence in the general population and possible sources. 


\section{References}

1. Liu YY, Wang Y, Walsh TR, Yi LX, Zhang R, Spencer J, et al. Emergence of plasmidmediated colistin resistance mechanism MCR-1 in animals and human beings in China: a microbiological and molecular biological study. Lancet Infect Dis. 2016;16(2):161-8.

2. Olaitan AO, Morand S, Rolain JM. Mechanisms of polymyxin resistance: acquired and intrinsic resistance in bacteria. Front Microbiol. 2014;5:643.

3. Nordmann P. Carbapenemase-producing Enterobacteriaceae: overview of a major public health challenge. Med Mal Infect. 2014;44(2):51-6.

4. von Wintersdorff CJ, Penders J, van Niekerk JM, Mills ND, Majumder S, van Alphen LB, et al. Dissemination of Antimicrobial Resistance in Microbial Ecosystems through Horizontal Gene Transfer. Front Microbiol. 2016;7:173.

5. Malhotra-Kumar S, Xavier BB, Das AJ, Lammens C, Hoang HT, Pham NT, et al. Colistinresistant Escherichia coli harbouring mcr-1 isolated from food animals in Hanoi, Vietnam. Lancet Infect Dis. 2016;16(3):286-7.

6. Suzuki S, Ohnishi M, Kawanishi M, Akiba M, Kuroda M. Investigation of a plasmid genome database for colistin-resistance gene mcr-1. Lancet Infect Dis. 2016;16(3):284-5.

7. Hu Y, Liu F, Lin IY, Gao GF, Zhu B. Dissemination of the mcr-1 colistin resistance gene. Lancet Infect Dis. 2016;16(2):146-7.

8. Elnahriry SS, Khalifa HO, Soliman AM, Ahmed AM, Hussein AM, Shimamoto T, et al. Emergence of Plasmid-Mediated Colistin Resistance Gene mcr-1 in a Clinical Escherichia coli Isolate from Egypt. Antimicrob Agents Chemother. 2016;60(5):324950.

9. Kuo SC, Huang WC, Wang HY, Shiau YR, Cheng MF, Lauderdale TL. Colistin resistance gene mcr-1 in Escherichia coli isolates from humans and retail meats, Taiwan. J Antimicrob Chemother. 2016.

10. Nguyen NT, Nguyen HM, Nguyen CV, Nguyen TV, Nguyen MT, Thai HQ, et al. Use of Colistin and Other Critical Antimicrobials on Pig and Chicken Farms in Southern Vietnam and Its Association with Resistance in Commensal Escherichia coli Bacteria. Appl Environ Microbiol. 2016;82(13):3727-35.

11. Falgenhauer L, Waezsada SE, Yao Y, Imirzalioglu C, Kasbohrer A, Roesler U, et al. Colistin resistance gene mcr-1 in extended-spectrum beta-lactamase-producing and carbapenemase-producing Gram-negative bacteria in Germany. Lancet Infect Dis. 2016;16(3):282-3.

12. Haenni M, Poirel L, Kieffer N, Chatre P, Saras E, Metayer V, et al. Co-occurrence of extended spectrum beta lactamase and MCR-1 encoding genes on plasmids. Lancet Infect Dis. 2016;16(3):281-2.

13. Hasman $H$, Hammerum AM, Hansen F, Hendriksen RS, Olesen B, Agerso $Y$, et al. Detection of mcr-1 encoding plasmid-mediated colistin-resistant Escherichia coli isolates from human bloodstream infection and imported chicken meat, Denmark 2015. Euro Surveill. 2015;20(49).

14. Malhotra-Kumar S, Xavier BB, Das AJ, Lammens C, Butaye P, Goossens H. Colistin resistance gene mcr-1 harboured on a multidrug resistant plasmid. Lancet Infect Dis. 2016;16(3):283-4. 
15. Poirel L, Kieffer N, Liassine N, Thanh D, Nordmann P. Plasmid-mediated carbapenem and colistin resistance in a clinical isolate of Escherichia coli. Lancet Infect Dis. 2016;16(3):281.

16. Webb HE, Granier SA, Marault M, Millemann Y, den Bakker HC, Nightingale KK, et al. Dissemination of the mcr-1 colistin resistance gene. Lancet Infect Dis. 2016;16(2):144-5.

17. Tse $H$, Yuen KY. Dissemination of the mcr-1 colistin resistance gene. Lancet Infect Dis. 2016;16(2):145-6.

18. Zurfuh K, Poirel L, Nordmann P, Nuesch-Inderbinen M, Hachler H, Stephan R. Occurrence of the Plasmid-Borne mcr-1 Colistin Resistance Gene in ExtendedSpectrum-beta-Lactamase-Producing Enterobacteriaceae in River Water and Imported Vegetable Samples in Switzerland. Antimicrob Agents Chemother. 2016;60(4):2594-5.

19. Perrin-Guyomard A, Bruneau M, Houee P, Deleurme K, Legrandois P, Poirier C, et al. Prevalence of mcr-1 in commensal Escherichia coli from French livestock, 2007 to 2014. Euro Surveill. 2016;21(6).

20. Cannatelli A, Giani T, Antonelli A, Principe L, Luzzaro F, Rossolini GM. First Detection of the mcr-1 Colistin Resistance Gene in Escherichia coli in Italy. Antimicrob Agents Chemother. 2016;60(5):3257-8.

21. Quesada A, Ugarte-Ruiz M, Iglesias MR, Porrero MC, Martinez R, Florez-Cuadrado D, et al. Detection of plasmid mediated colistin resistance (MCR-1) in Escherichia coli and Salmonella enterica isolated from poultry and swine in Spain. Res Vet Sci. 2016;105:134-5.

22. Doumith M, Godbole G, Ashton P, Larkin L, Dallman T, Day M, et al. Detection of the plasmid-mediated mcr-1 gene conferring colistin resistance in human and food isolates of Salmonella enterica and Escherichia coli in England and Wales. J Antimicrob Chemother. 2016.

23. Olaitan AO, Chabou S, Okdah L, Morand S, Rolain JM. Dissemination of the mcr-1 colistin resistance gene. Lancet Infect Dis. 2016;16(2):147.

24. Grami R, Mansour W, Mehri W, Bouallegue O, Boujaafar N, Madec JY, et al. Impact of food animal trade on the spread of mcr-1-mediated colistin resistance, Tunisia, July 2015. Euro Surveill. 2016;21(8).

25. Skov RL, Monnet DL. Plasmid-mediated colistin resistance (mcr-1 gene): three months later, the story unfolds. Euro Surveill. 2016;21(9).

26. von Wintersdorff CJ, Penders J, Stobberingh EE, Oude Lashof AM, Hoebe CJ, Savelkoul $\mathrm{PH}$, et al. High rates of antimicrobial drug resistance gene acquisition after international travel, The Netherlands. Emerg Infect Dis. 2014;20(4):649-57.

27. EUCAST. Breakpoint tables for interpretation of MICs and zone diameters. Version 6.0. Available from: http://www.eucast.org/clinical_breakpoints/.

28. Gautom RK. Rapid pulsed-field gel electrophoresis protocol for typing of Escherichia coli 0157:H7 and other gram-negative organisms in 1 day. J Clin Microbiol. 1997;35(11):2977-80.

29. Tenover FC, Arbeit RD, Goering RV, Mickelsen PA, Murray BE, Persing DH, et al. Interpreting chromosomal DNA restriction patterns produced by pulsed-field gel electrophoresis: criteria for bacterial strain typing. J Clin Microbiol. 1995;33(9):22339. 
30. Wirth T, Falush D, Lan R, Colles F, Mensa P, Wieler LH, et al. Sex and virulence in Escherichia coli: an evolutionary perspective. Mol Microbiol. 2006;60(5):1136-51.

31. Bontron S, Poirel L, Nordmann P. Real-time PCR for detection of plasmid-mediated polymyxin resistance (mcr-1) from cultured bacteria and stools. J Antimicrob Chemother. 2016.

32. Kluytmans-van den Bergh MF, Huizinga $P$, Bonten MJ, Bos M, De Bruyne K, Friedrich $\mathrm{AW}$, et al. Presence of mcr-1-positive Enterobacteriaceae in retail chicken meat but not in humans in the Netherlands since 2009. Euro Surveill. 2016;21(9).

33. Arcilla MS, van Hattem JM, Matamoros S, Melles DC, Penders J, de Jong MD, et al. Dissemination of the mcr-1 colistin resistance gene. Lancet Infect Dis. 2016;16(2):147-9.

34. Shen Z, Wang Y, Shen Y, Shen J, Wu C. Early emergence of mcr-1 in Escherichia coli from food-producing animals. Lancet Infect Dis. 2016;16(3):293.

35. Bonten MJ. [Antimicrobial resistance: is it really all going wrong now?]. Ned Tijdschr Geneeskd. 2016;160(0):D81.

36. Hassing RJ, Alsma J, Arcilla MS, van Genderen PJ, Stricker BH, Verbon A. International travel and acquisition of multidrug-resistant Enterobacteriaceae: a systematic review. Euro Surveill. 2015;20(47). 


\section{Chapter 7}

General discussion and summary 


\section{The role of the resistome $\&$ antibiotic resistance in patient care}

The emergence and spread of antibiotic resistance among pathogenic bacteria is a growing threat for public health worldwide. With increasing resistance against even the last resort antibiotics, this problem is now reaching a level where an increasing number of infections are extremely difficult to treat or may even become completely untreatable [1, 2]. In chapter $\mathbf{2}$, we underscore the importance of that not only antibiotic resistance in clinically relevant pathogens is of importance. In various environments, bacteria live in complex communities, where they are able to exchange genes via horizontal gene transfer (HGT). Thus, these communities can act as reservoirs of resistance, in which antibiotic resistance genes (ARGs) in one species can be transferred to other, potentially pathogenic, bacteria.

The significance of such reservoirs with regard to the resistance that is encountered in the clinic has been demonstrated by several gene transfer events. Perhaps the most important example is the one concerning the bla ${ }_{\mathrm{CTX}-\mathrm{M}}$ genes, currently the most prevalent extended-spectrum $\beta$-lactamases (ESBLs) encoding genes in Enterobacteriaceae worldwide [3], which originate from various environmental Kluyvera species [4]. Several other gene transfer events from commensals or even waterborne environmental bacteria into human pathogens have been described [5-8], and many other clinically relevant ARGs are believed to have originated from non-pathogenic bacteria.

Because of such interactions both within and between these different communities, the effects of antibiotic selection pressure on not only pathogens, but all microbes in our gut, other animals, and the environment should be taken into account. An increase of resistome elements within these microbial ecosystems, even if not directly in human pathogens, may eventually reach into the clinic and have major consequences for public health. 


\section{The human gut resistome}

As any other microbial community, the human gut microbiome harbours numerous antibiotic resistance genes (Ch 4A, 4B, [9-14]). With the potential of HGT within these resistance reservoirs in mind (Ch 2), the human gut microbiota warrants special attention, due to its high density of microorganisms [11, 13]. The gastrointestinal tract is constantly exposed to numerous bacteria from the environment, via e.g. food, water, soil and other humans or animals. These incoming bacteria often harbour antibiotic resistance genes [15], which may be transferred to the indigenous microbial communities, enriching the pool of available AMR elements in the gut microbiota. While some studies have shown that ARGs are present within the gut microbiota from early life and without any previous antibiotic exposure [16-18], data on how the gut resistome develops and how it is influenced by external factors is limited. Changes to the developing microbiota may however permanently alter both its composition as well as its associated resistome.

In chapter $\mathbf{3}$ we showed that already within a few weeks after birth, several ARGs can be detected in the gut microbiota of infants. At later time points, the prevalence of most genes increased, suggesting that they slowly accumulate as the microbiota develops. The aminoglycoside resistance encoding gene aac $\left(6^{\prime}\right)$ $a p h\left(2^{\prime \prime}\right)$ became less prevalent over time however, indicating that some ARGs are lost or become less abundant. During infancy and early childhood, the microbial composition fluctuates rapidly and is influenced by many different factors, such as the mode of delivery, type of infant feeding, gestational age and antibiotic use $[19,20]$. In part, we were able to show that the observed fluctuations in ARGs were correlated to fluctuations in certain groups of bacteria (e.g. a higher abundance of bacteroides), and concluded that the composition of the resistome at this age is largely shaped by the shifts in the bacterial community structure of the gut. Likely related to this finding, we showed that factors such as the mode of birth and the duration of breastfeeding, not only affected the gastrointestinal microbial composition but also the prevalence of several ARGs. While our results provide a representation of microbial composition changes by looking at several main bacterial groups, a more detailed correlation between changes in ARGs and microbial composition by performing $16 \mathrm{~S}$ rDNA sequencing could provide further insights. In their study on the gut resistome development of twins, Moore et al. showed that environmental factors early in life shape resistome development 
and, in agreement with our study, concluded that infants' gut resistomes are likely a reflection of community composition [21]. Together with our results, this indicates that early exposure to organisms harbouring resistance determinants which may be shared with opportunistic pathogens could lead to their establishment in resistome and pose a risk for future infections.

\section{Travel and the spread of antibiotic resistance}

In an era of increasing globalization, the acquisition and dissemination of antibiotic resistant bacteria through international travel is a major concern. While exposure to antibiotic resistant bacteria during a travel is a risk for developing infections with such resistant bacteria, the geographic transfer of resistome elements could also lead to their introduction and further dissemination in other environments.

In chapter 4A we investigated the effect of international travel on the gut resistome in a prospective cohort study. The results of this study show that genes encoding ESBLs ( $b / a_{\text {CTX-M }}$ ) were acquired at high rates in travellers who visited Asia of Africa. Especially travellers who visited the Indian subcontinent were at high risk for acquiring $b / a_{\text {CTX-M }}(>58 \%)$. Previous studies investigating the acquisition of ESBL-producing Enterobacteriaceae in travellers have also shown high acquisition rates (up to 88\%) for destinations in Southern Asia [22]. This indicates that travel to these area's is an important factor contributing to the dissemination of ARGs from endemic to low prevalence areas. Due to our metagenomic approach, we were able to demonstrate that other ARGs were acquired during travel as well. This became apparent from the finding that the plasmid mediated quinolone resistance genes ( $q n r B$ and $q n r S$ ) were also acquired at high rates. For qnrS, the risk was the greatest for travellers who visited Asia, and especially those that visited Cambodia, Thailand or Vietnam ( $>81 \%$ acquisition). The latter country has previously shown to be highly endemic for qnr genes [23]. While our study focused on a selection of ARGs, these findings highlights the high probability of many other ARGs, which are endemic in certain areas, being introduced to low prevalence areas by travellers. With regard to this, there is likely an import of carbapenemase genes from high prevalence countries in the Mediterranean area such as Italy [24], Turkey and Greece [25, 26]. Travellers to these area's generally do not visit travel clinics and actual data, while relevant, are therefore unfortunately very limited. A follow-up on this particular study population was not 
performed, and thus it is unknown for how long the acquired ARGs remained in the gut microbiome. While some studies have investigated the persistence of acquired ESBL producers using culture based methods [27-30], additional efforts from metagenomic studies will provide insights on the dynamics and fate of acquired ARGs.

In chapter $4 \mathrm{~A}$ we described the observation that in adults some ARGs were already highly prevalent before international travel and fluctuated in their abundance. This could be putatively attributed to effects of traveling. In chapter 4B we showed however that in non-travelling adults, similar fluctuations were observed for these specific ARGs and therefore likely represent normal short term changes in the commensal microbiota. Changes in microbial composition during international travel have thus far not been investigated, but may be correlated with acquisitions of specific ARGs. For example, individuals with a decreased colonization resistance may be more prone to microbial composition changes, including increases of Enterobacteriaceae and their associated ARGs.

While we [31, 32] and others [22, 33-35] have shown that acquisition of ARGs and antibiotic resistant bacteria takes place during international travel, no data were available on how rapid ARG acquisition may actually take place. This prompted us to focus on the dynamics of the resistome during the actual travel in chapter 5 . By collecting consecutive samples before, during as well as after travel, we were able to show that acquisition of ARGs can take place within days. The median time to acquisition was 5 days, indicating that acquisition occurs rapidly and even short visits to endemic areas are sufficient to contribute to the dissemination of antibiotic resistance. This also highlights the possible implications for short visits to other types of high-risk environments, such as hospitals or farms. While it only takes a short time for acquisition to take place, its effects may be long lasting. In our limited population size, ARGs were in some cases detectable up to 3 months after travel. Other studies have shown that resistant organisms acquired during travel persisted up to 6 months in $6-24 \%$ of the travellers [27-30]. As long as carriage persists, there is an increased risk for infections with such resistant bacteria [36], as well as for further dissemination to e.g. household members [37]. Moreover, there is a constant exposure of the environment through excretion of resistant bacteria or ARGs (Ch 2).

The first plasmid-mediated colistin resistance gene, $\mathrm{mcr}-1$, has only recently been described. The dissemination of this gene may have major consequences, as it can render multidrug resistant bacteria unsusceptible to even the last available 
treatment option. Information on the extent to which this gene has disseminated globally is still limited. While the rates of mcr-1 positive strains isolated from animals or food in certain regions was quite high according to some studies [38, 39], the reported carriage rate in humans in Europe thus far remains sporadic [40]. In chapter 6 we investigated whether travellers were being exposed to this gene, thereby possibly contributing to its dissemination. In a PCR, metagenome samples are more prone to induce unspecific amplification due to the high diversity of DNA templates present compared to e.g. DNA isolated from bacterial isolates. Moreover, the assay described by Liu et al [41] was previously shown to generate false-positives on bacterial isolates [42]. To be able to reliably investigate the (faecal) metagenome for $m c r-1$, we therefore developed a new real time PCR. With this sensitive and specific PCR assay, we found that for one participant, the $\mathrm{mcr}-1$ gene was detected in both the pre- and post-travel sample, whereas for 5 other participants only the post-travel sample was found to be positive. This suggests that this gene is already present at high rates in certain parts of the world, and confirms that travel to such high-risk areas is a risk factor for its acquisition and further dissemination.

Bacterial isolates harbouring the $m c r-1$ gene could not be isolates from all faecal samples in which the gene was detected. While it is likely that this is due to decreased bacteria viability in those samples, it would be interesting to determine the location of the detected genes, as they could also be present in non-readily cultivable bacteria. As such, additional studies are required to more extensively determine the role of travel in the dissemination of $m c r-1$. Due to its recent discovery and possible implications for antibiotic therapy, a great amount of research from various parts of the world is being performed on mcr-1 [40, 43]. The results of these and future studies will provide much more needed insights into its prevalence and importance in humans, animals and the environment. From this, we may assess the gravity of the $m c r-1$ situation and act accordingly. A number of findings indicate that $m c r-1$ may be of animal-associated bacterial origin [44], which prompts for heavy restriction or even a ban of polymyxin usage in agriculture. 


\section{Concluding remarks and future perspectives}

Considering the emergence of antibiotic resistance since the use of antibiotics by humans, it is clear that efforts must be made to prevent its further dissemination. If we wish to maintain the therapeutic use of current antibiotics, and perhaps even more importantly: those which may be discovered or synthesized in the future, certain measures must be undertaken globally. Some major issues which would need to be addressed are for example: (I) the massive exposure of the environment to antibiotic waste; (II) the mass use of antibiotics as growth promotors and prophylactic medicine in agriculture, and; (III) the nonprescribed and inadequate use of antibiotics for human medicine.

Efforts to better regulate those issues are being made in certain parts of the world; as for example antibiotic stewardship is increasingly employed in healthcare facilities [45]. Also, in several northern European countries major improvements in agricultural use of antibiotics have been achieved [46, 47]. The effects of such regulations will remain largely limited to specific area's or countries however, as in other parts of the world, extreme opposites such as completely unregulated 'over the counter' sale of antibiotics is still common practice [48-50], regulations for agricultural use of antibiotics are lacking [51] and uncontrolled exposure of the environment to antibiotics is dramatic [52].

Despite the fact that a lack of such regulations may be regional, it will continue to drive a global increase in the prevalence of antibiotic resistant bacteria through e.g. trade and travel networks. Therefore, there is still a need to more clearly define the impact of travelling on the dissemination of antibiotic resistance. Future studies need to further clarify how long acquisition of ARGs or resistant bacteria is maintained, what risk this poses, and whether further dissemination to e.g. household members or the environment takes place. Additionally, the acquisition of carbapenemase-encoding genes from travel to endemic countries, as well as that of $m c r-1$ is still understudied and will be a valuable point of focus. Since carbapenems and polymyxins will be increasingly required as treatment options, it is pivotal to better identify dissemination routes of genes encoding resistance to these last-resort antibiotics. Unravelling human-to-human or environmental dissemination routes might provide new leads to enforce additional (hygiene) precautions e.g. in case of hospital admittance of patients who recently travelled to endemic areas. There is also a need to more clearly define the consequences of the dissemination of ARGs by human activities in 
general. It is for example poorly understood how the introduction of (organisms harbouring) ARGs into an environment affect its resistome. This includes the initial acquisition of ARGs into the gut resistome of humans or animals, but also their subsequent dissemination into e.g. the direct environment of the microbe's host, or to wastewaters, and so on. Eventually, it will be essential to investigate to what degree such effects are linked to antibiotic resistance encountered in the clinic.

Currently, the breach in the last line of available antibiotics for multidrug resistance by the discovery of $m c r-1$ and $m c r-2$ [53] has emphasized that novel antibiotics are desperately required. Just as largely unexplored bacterial ecosystems contain numerous ARGs, they are most likely also an untapped source of novel antibiotics. Similar to how teixobactin was recently discovered [54], novel ways to cultivate microorganisms from ecosystems such as the soil or marine environment $[55,56]$ may therefore lead to the discovery of new antibiotics. Strict regulations, as discussed earlier, for the use of any of such novel antibiotics will be required however. If such regulations are not upheld, there is no reason their therapeutic use will not meet the same fate as that of the current antibiotics. Most likely, resistance against such novel antibiotics will emerge from the same ecosystems from which they were discovered, and the use of metagenomics could identify and monitor such resistance before it emerges in human pathogens, if not already present there. Similarly, by performing functional metagenomic studies, novel genes encoding resistance against the current antibiotics will be identified. This will improve the annotation power of sequence based studies and will allow for more information to be extracted from the sequencing of bacterial communities, as well as from already existing sequence data. Also, the identification of unknown ARGs will allow for targeted metagenomic approaches to interrogate such communities for the presence and abundance of those genes.

Thus, by employing a combination of these different metagenomic techniques, the presence and spread of antibiotic resistance not only in human pathogens, but in all bacterial ecosystems which serve as a potential reservoir of resistance can be further unravelled. Such efforts will be required in order to take appropriate measures to limit the dissemination of resistance against both the current, and any novel antibiotics. 


\section{References}

1. Nordmann P. Carbapenemase-producing Enterobacteriaceae: overview of a major public health challenge. Med Mal Infect. 2014;44(2):51-6.

2. Paterson DL, Harris PN. Colistin resistance: a major breach in our last line of defence. Lancet Infect Dis. 2016;16(2):132-3.

3. Hawkey PM, Jones AM. The changing epidemiology of resistance. J Antimicrob Chemother. 2009;64 Suppl 1:i3-10.

4. Canton R, Coque TM. The CTX-M beta-lactamase pandemic. Curr Opin Microbiol. 2006;9(5):466-75.

5. Poirel L, Liard A, Rodriguez-Martinez JM, Nordmann P. Vibrionaceae as a possible source of Qnr-like quinolone resistance determinants. J Antimicrob Chemother. 2005;56(6):1118-21.

6. Poirel L, Potron A, Nordmann P. OXA-48-like carbapenemases: the phantom menace. J Antimicrob Chemother. 2012;67(7):1597-606.

7. Poirel L, Rodriguez-Martinez JM, Mammeri H, Liard A, Nordmann P. Origin of plasmid-mediated quinolone resistance determinant QnrA. Antimicrob Agents Chemother. 2005;49(8):3523-5.

8. Howden BP, Holt KE, Lam MM, Seemann T, Ballard S, Coombs GW, et al. Genomic insights to control the emergence of vancomycin-resistant enterococci. MBio. 2013;4(4).

9. Salyers AA, Gupta A, Wang Y. Human intestinal bacteria as reservoirs for antibiotic resistance genes. Trends Microbiol. 2004;12(9):412-6.

10. Sommer MO, Dantas G, Church GM. Functional characterization of the antibiotic resistance reservoir in the human microflora. Science. 2009;325(5944):1128-31.

11. van Schaik W. The human gut resistome. Philos Trans R Soc Lond B Biol Sci. 2015;370(1670):20140087.

12. von Wintersdorff CJ, Penders J, van Niekerk JM, Mills ND, Majumder S, van Alphen LB, et al. Dissemination of Antimicrobial Resistance in Microbial Ecosystems through Horizontal Gene Transfer. Front Microbiol. 2016;7:173.

13. Penders J, Stobberingh EE, Savelkoul PH, Wolffs PF. The human microbiome as a reservoir of antimicrobial resistance. Front Microbiol. 2013;4:87.

14. Huddleston JR. Horizontal gene transfer in the human gastrointestinal tract: potential spread of antibiotic resistance genes. Infect Drug Resist. 2014;7:167-76.

15. Baquero F. Metagenomic epidemiology: a public health need for the control of antimicrobial resistance. Clin Microbiol Infect. 2012;18 Suppl 4:67-73.

16. Zhang L, Kinkelaar D, Huang Y, Li Y, Li X, Wang HH. Acquired antibiotic resistance: are we born with it? Appl Environ Microbiol. 2011;77(20):7134-41.

17. Fouhy F, Ogilvie LA, Jones BV, Ross RP, Ryan AC, Dempsey EM, et al. Identification of aminoglycoside and beta-lactam resistance genes from within an infant gut functional metagenomic library. PLoS ONE. 2014;9(9):e108016.

18. Moore AM, Patel S, Forsberg KJ, Wang B, Bentley G, Razia Y, et al. Pediatric fecal microbiota harbor diverse and novel antibiotic resistance genes. PLoS ONE. 2013;8(11):e78822. 
19. Penders J, Thijs C, Vink C, Stelma FF, Snijders B, Kummeling I, et al. Factors influencing the composition of the intestinal microbiota in early infancy. Pediatrics. 2006;118(2):511-21.

20. Dominguez-Bello MG, Costello EK, Contreras M, Magris M, Hidalgo G, Fierer N, et al. Delivery mode shapes the acquisition and structure of the initial microbiota across multiple body habitats in newborns. Proc Natl Acad Sci U S A. 2010;107(26):11971-5.

21. Moore AM, Ahmadi S, Patel S, Gibson MK, Wang B, Ndao MI, et al. Gut resistome development in healthy twin pairs in the first year of life. Microbiome. 2015;3:27.

22. Hassing RJ, Alsma J, Arcilla MS, van Genderen PJ, Stricker BH, Verbon A. International travel and acquisition of multidrug-resistant Enterobacteriaceae: a systematic review. Euro Surveill. 2015;20(47).

23. Vien le TM, Minh NN, Thuong TC, Khuong HD, Nga TV, Thompson C, et al. The coselection of fluoroquinolone resistance genes in the gut flora of Vietnamese children. PLoS ONE. 2012;7(8):e42919.

24. Tascini C, Sbrana F, Flammini S, Tagliaferri E, Arena F, Leonildi A, et al. Oral gentamicin gut decontamination for prevention of KPC-producing Klebsiella pneumoniae infections: relevance of concomitant systemic antibiotic therapy. Antimicrob Agents Chemother. 2014;58(4):1972-6.

25. Nordmann P, Poirel L. The difficult-to-control spread of carbapenemase producers among Enterobacteriaceae worldwide. Clin Microbiol Infect. 2014;20(9):821-30.

26. Doi Y, Paterson DL. Carbapenemase-producing Enterobacteriaceae. Semin Respir Crit Care Med. 2015;36(1):74-84.

27. Kennedy K, Collignon P. Colonisation with Escherichia coli resistant to "critically important" antibiotics: a high risk for international travellers. Eur J Clin Microbiol Infect Dis. 2010;29(12):1501-6.

28. Paltansing S, Vlot JA, Kraakman MEM, Mesman R, Bruijning ML, Bernards AT, et al. Extended-Spectrum $\beta$-Lactamase-producing Enterobacteriaceae among Travelers from the Netherlands. Emerg Infect Dis. 2013;19(8):1206-13.

29. Ruppe E, Armand-Lefevre L, Estellat C, Consigny PH, El Mniai A, Boussadia Y, et al. High Rate of Acquisition but Short Duration of Carriage of Multidrug-Resistant Enterobacteriaceae After Travel to the Tropics. Clin Infect Dis. 2015;61(4):593-600.

30. Tangden $T$, Cars $O$, Melhus A, Lowdin E. Foreign travel is a major risk factor for colonization with Escherichia coli producing CTX-M-type extended-spectrum betalactamases: a prospective study with Swedish volunteers. Antimicrob Agents Chemother. 2010;54(9):3564-8.

31. von Wintersdorff CJ, Penders J, Stobberingh EE, Oude Lashof AM, Hoebe CJ, Savelkoul PH, et al. High rates of antimicrobial drug resistance gene acquisition after international travel, The Netherlands. Emerg Infect Dis. 2014;20(4):649-57.

32. von Wintersdorff CJ, Wolffs PF, van Niekerk JM, Beuken E, van Alphen LB, Stobberingh EE, et al. Detection of the plasmid-mediated colistin-resistance gene mcr-1 in faecal metagenomes of Dutch travellers. J Antimicrob Chemother. 2016;in press.

33. Arcilla MS, van Hattem JM, Matamoros S, Melles DC, Penders J, de Jong MD, et al. Dissemination of the mcr-1 colistin resistance gene. Lancet Infect Dis. 2016;16(2):147-9. 
34. Barreto Miranda IDM, Ignatius RPDM, Pfuller RDM, Friedrich-Janicke BDM, Steiner FDM, Paland MDM, et al. High carriage rate of ESBL-producing Enterobacteriaceae at presentation and follow-up among travellers with gastrointestinal complaints returning from India and Southeast Asia. J Travel Med. 2016;23(2).

35. Reuland EA, Sonder GJ, Stolte I, AI Naiemi N, Koek A, Linde IB, et al. Travel to Asia and traveller's diarrhoea with antibiotic treatment are independent risk factors for acquiring ciprofloxacin-resistant and extended spectrum betalactamase-producing Enterobacteriaceae - a prospective cohort study. Clin Microbiol Infect. 2016.

36. Vodovar D, Marcade G, Rousseau H, Raskine L, Vicaut E, Deye N, et al. Predictive factors for extended-spectrum beta-lactamase producing Enterobacteriaceae causing infection among intensive care unit patients with prior colonization. Infection. 2014;42(4):743-8.

37. Arcilla MS, van Hattem JM, Bootsma MC, van Genderen PJ, Goorhuis A, Schultsz C, et al. The Carriage Of Multiresistant Bacteria After Travel (COMBAT) prospective cohort study: methodology and design. BMC Public Health. 2014;14:410.

38. Grami R, Mansour W, Mehri W, Bouallegue O, Boujaafar N, Madec JY, et al. Impact of food animal trade on the spread of mcr-1-mediated colistin resistance, Tunisia, July 2015. Euro Surveill. 2016;21(8).

39. Malhotra-Kumar S, Xavier BB, Das AJ, Lammens C, Hoang HT, Pham NT, et al. Colistinresistant Escherichia coli harbouring mcr-1 isolated from food animals in Hanoi, Vietnam. Lancet Infect Dis. 2016;16(3):286-7.

40. Skov RL, Monnet DL. Plasmid-mediated colistin resistance (mcr-1 gene): three months later, the story unfolds. Euro Surveill. 2016;21(9).

41. Liu YY, Wang Y, Walsh TR, Yi LX, Zhang R, Spencer J, et al. Emergence of plasmidmediated colistin resistance mechanism MCR-1 in animals and human beings in China: a microbiological and molecular biological study. Lancet Infect Dis. 2016;16(2):161-8.

42. Bontron S, Poirel L, Nordmann P. Real-time PCR for detection of plasmid-mediated polymyxin resistance (mcr-1) from cultured bacteria and stools. J Antimicrob Chemother. 2016.

43. Schwarz S, Johnson AP. Transferable resistance to colistin: a new but old threat. J Antimicrob Chemother. 2016.

44. Poirel L, Nordmann P. Emerging plasmid-encoded colistin resistance: the animal world as the culprit? J Antimicrob Chemother. 2016.

45. Morrill HJ, Caffrey AR, Jump RL, Dosa D, LaPlante KL. Antimicrobial Stewardship in Long-Term Care Facilities: A Call to Action. J Am Med Dir Assoc. 2016;17(2):183 e116.

46. Bengtsson B, Wierup $M$. Antimicrobial resistance in Scandinavia after ban of antimicrobial growth promoters. Anim Biotechnol. 2006;17(2):147-56.

47. Maron DF, Smith TJ, Nachman KE. Restrictions on antimicrobial use in food animal production: an international regulatory and economic survey. Global Health. 2013;9:48.

48. Hadi U, van den Broek P, Kolopaking EP, Zairina N, Gardjito W, Gyssens IC. Crosssectional study of availability and pharmaceutical quality of antibiotics requested with or without prescription (Over The Counter) in Surabaya, Indonesia. BMC Infect Dis. 2010;10:203. 
49. Gebretekle GB, Serbessa MK. Exploration of over the counter sales of antibiotics in community pharmacies of Addis Ababa, Ethiopia: pharmacy professionals' perspective. Antimicrob Resist Infect Control. 2016;5:2.

50. Van Boeckel TP, Gandra S, Ashok A, Caudron Q, Grenfell BT, Levin SA, et al. Global antibiotic consumption 2000 to 2010: an analysis of national pharmaceutical sales data. Lancet Infect Dis. 2014;14(8):742-50.

51. Van Boeckel TP, Brower C, Gilbert M, Grenfell BT, Levin SA, Robinson TP, et al. Global trends in antimicrobial use in food animals. Proc Natl Acad Sci U S A. 2015;112(18):5649-54.

52. Larsson DG, de Pedro C, Paxeus N. Effluent from drug manufactures contains extremely high levels of pharmaceuticals. J Hazard Mater. 2007;148(3):751-5.

53. Xavier BB, Lammens C, Ruhal R, Kumar-Singh S, Butaye P, Goossens $H$, et al. Identification of a novel plasmid-mediated colistin-resistance gene, $\mathrm{mcr}-2$, in Escherichia coli, Belgium, June 2016. Euro Surveill. 2016;21(27).

54. Ling LL, Schneider T, Peoples AJ, Spoering AL, Engels I, Conlon BP, et al. A new antibiotic kills pathogens without detectable resistance. Nature. 2015;517(7535):455-9.

55. Joint I, Muhling M, Querellou J. Culturing marine bacteria - an essential prerequisite for biodiscovery. Microb Biotechnol. 2010;3(5):564-75.

56. Stewart EJ. Growing unculturable bacteria. J Bacteriol. 2012;194(16):4151-60. 
Samenvatting 


\section{De rol van het resistoom \& antibioticaresistentie in de patiëntenzorg}

De opkomst en verspreiding van antibioticaresistentie onder pathogene bacteriën is wereldwijd een toenemend probleem voor de volksgezondheid. Door toenemende resistentie tegen zelfs de laatste redmiddelen onder de antibiotica, bereikt dit probleem nu een punt waarop een toenemend aantal infecties erg moeilijk, of zelfs onmogelijk te behandelen zijn. In hoofdstuk $\mathbf{2}$ benadrukken we het belangrijke feit dat niet enkel antibioticaresistentie zoals die voorkomt in klinisch relevante pathogenen van belang is. In diverse omgevingen leven bacteriën in complexe gemeenschappen, waar zij genen met elkaar kunnen uitwisselen door middel van horizontale gen overdracht. Derhalve fungeren deze gemeenschappen als reservoirs van resistentie, waar antibioticaresistentie genen (ARGs) van de ene bacteriesoort kunnen worden overgedragen naar andere, mogelijk pathogene, bacteriën.

Het belang van zulke reservoirs met betrekking tot de resistentie die in de kliniek wordt aangetroffen, is door verscheidene gebeurtenissen van gen overdracht aangetoond. De bla $a_{\mathrm{CTX}-\mathrm{M}}$ genen zijn daar misschien wel het meest belangrijke voorbeeld van. Deze genen, die hun oorsprong hebben in de omgevings-bacterie Kluyvera, zijn momenteel de meest voorkomende oorzaak van extended-spectrum $\beta$-lactamase (ESBL) productie in Enterobacteriaceae. $\mathrm{Er}$ zijn meerdere van dit soort uitwisselingen bekend waarbij genetica vanuit commensalen of bacteriën uit een water milieu is overgedragen aan menselijke pathogenen. Daarnaast wordt van de meeste klinisch relevante ARGs verondersteld dat deze afkomstig zijn van niet-pathogene bacteriën.

Ten gevolge van deze interacties binnen en tussen deze verschillende gemeenschappen, moet er rekening worden gehouden met de effecten van antibiotica selectiedruk op niet alleen pathogenen, maar ook alle overige microben in zulke gemeenschappen, zoals in onze darmen, andere dieren en ook de omgeving. Een verhoging van resistoom elementen in deze microbiële ecosystemen, zelfs wanneer dit niet direct in menselijke pathogenen is, kan uiteindelijk tot in de kliniek reiken en op die manier grote gevolgen hebben voor de volksgezondheid. 


\section{Het menselijke darmresistoom}

Net zoals elke andere microbiële gemeenschap, bevat het menselijke darmmicrobioom talloze ARGs (hoofdstukken 4A, 4B). Met het potentieel van horizontale gen overdracht in deze resistentiereservoirs in gedachten, verdient de menselijke darmmicrobiota speciale aandacht door de hoge dichtheid aan microorganismen. Het gastro-intestinale stelsel wordt constant blootgesteld aan talloze bacteriën vanuit de omgeving via bijvoorbeeld voedsel, water, de grond of andere mensen en dieren. Deze binnenkomende bacteriën bevatten veelal ARGs, welke mogelijk overgedragen kunnen worden aan de oorspronkelijk aanwezige bacteriële gemeenschap. Op deze manier kan de voorraad aanwezige antibioticaresistentie elementen in de darmmicrobiota verhoogd worden. Hoewel enkele studies hebben laten zien dat ARGs al aanwezig zijn op jonge leeftijd en zonder voorafgaand antibiotica gebruik, zijn de gegevens over hoe het darmresistoom ontwikkelt en wordt beïnvloed door externe factoren nog beperkt. Veranderingen in de ontwikkelende microbiota kunnen echter wijzigingen in zowel de samenstelling als het daarmee geassocieerde resistoom teweeg brengen.

In hoofdstuk 3 lieten we zien dat al binnen enkele weken na de geboorte verschillende ARGs detecteerbaar waren in de darmmicrobiota van kinderen. Op latere tijdstippen nam de prevalentie van de meeste genen toe. Hetgeen suggereert dat deze genen langzaam accumuleren gedurende de ontwikkeling van de microbiota. Het $a a c\left(6^{\prime}\right)-a p h\left(2^{\prime \prime}\right)$ gen, dat codeert voor aminoglycoside resistentie, werd echter minder prevalent over de tijd. Dit duidt erop dat sommige ARGs juist verdwijnen of verminderen in aantal. Tijdens de zuigelingenperiode en vroege kinderjaren verandert de microbiële samenstelling snel en wordt beïnvloed door verschillende factoren. Voorbeelden hiervan zijn de manier van geboorte, het type zuigelingenvoeding, de zwangerschapsduur en het antibiotica gebruik. Wij hebben laten zien dat de waargenomen veranderingen in ARGs gedeeltelijk gecorreleerd waren aan fluctuaties in bepaalde groepen bacteriën (bijvoorbeeld een hogere hoeveelheid bacteroides). Hieruit concludeerden we dat de samenstelling van het resistoom op deze leeftijd grotendeels gevormd wordt door de wijzigingen in de structuur van de bacteriële gemeenschap van de darmen. Ook lieten we zien dat factoren zoals de manier van geboorte en de duur van het geven van borstvoeding niet alleen invloed had op de darmmicrobiota samenstelling, maar ook op de prevalentie van verschillende ARGs. Onze 
resultaten geven een representatie van de veranderingen in de microbiële samenstelling door te kijken naar de verschillende bacteriegroepen. Het uitvoeren van 16s rDNA sequencing zou echter een meer gedetailleerde correlatie tussen deze veranderingen kunnen verschaffen. In hun studie over de darmresistoom ontwikkeling van tweelingen lieten Moore en collega's zien dat omgevingsfactoren in de vroege levensjaren vorm geven aan de resistoom ontwikkeling. In overeenkomst met onze resultaten, concludeerden zij dat het darmresistoom van de zuigeling waarschijnlijk een weerspiegeling is van de bacteriële gemeenschapssamenstelling. Samen met onze resultaten wijst dit erop dat vroege blootstelling aan organismen, die resistentiegenen bevatten welke gedeeld kunnen worden met opportunistische pathogenen, er toe kan lijden dat deze genen gevestigd worden in het resistoom en derhalve een mogelijk risico kunnen vormen voor toekomstige infecties.

\section{Reizen en de verspreiding van antibioticaresistentie}

In een tijdperk van toenemende globalisatie is het verkrijgen en de verspreiding van antibioticaresistente bacteriën ten gevolge van internationaal reizen een grote zorg. De blootstelling aan antibioticaresistente bacteriën tijdens een reis vormt een risico voor het ontwikkelen van infecties met zulke resistente bacteriën. Daarnaast kan de geografische verplaatsing van resistoom elementen ook leiden tot de introductie en verdere verspreiding van deze ARGs in andere omgevingen.

In hoofdstuk 4A hebben we het effect van internationaal reizen op het darmresistoom onderzocht in een prospectieve cohort studie. De resultaten van deze studie laten zien dat ESBL coderende genen (b/a $a_{\text {CTX-M }}$ ) in hoge mate werden verworven door reizigers die naar Azië of Afrika waren geweest. Met name reizigers die naar het Indiaas subcontinent waren geweest, hadden een hoog risico voor de acquisitie van bla $a_{\text {CTX-M }}(>58 \%)$. Uit voorgaande studies naar de acquisitie van ESBL producerende Enterobacteriaceae door reizigers, bleek ook dat dit risico erg hoog was voor bestemmingen in Zuid-Azië (tot wel 88\%). Dit duidt aan dat reizen naar deze gebieden een belangrijke factor is die bijdraagt aan de verspreiding van ARGs van endemische gebieden naar gebieden waar een lage prevalentie heerst. Dankzij onze metagenomische aanpak hebben we kunnen aantonen dat ook andere ARGs werden verworven tijdens het reizen. Dit werd duidelijk door de bevinding dat de plasmide gemedieerde quinolone resistentie 
genen ( $q n r B$ en $q n r S$ ) ook in hoge mate verworven werden. Voor qnrS was het risico het grootst voor reizigers die naar Azië gingen en vooral voor de reizigers die Cambodia, Thailand of Vietnam hadden bezocht ( $>81 \%$ acquisitie). Van het laatstgenoemde land werd eerder aangetoond dat het endemisch is voor qnr genen. Hoewel onze studie zich richtte op een selectie van ARGs, benadrukken deze bevindingen de hoge waarschijnlijkheid dat vele andere ARGs, welke endemisch zijn in bepaalde gebieden, door reizigers worden geïntroduceerd in gebieden met een lage prevalentie. Zo is er waarschijnlijk ook een import van carbapenemase genen vanuit hoge prevalentie landen in de mediterranen zoals Italië, Turkije en Griekenland. Reizigers die deze gebieden bezoeken gaan echter over het algemeen niet naar reisklinieken waardoor de gegevens hierover helaas erg beperkt zijn. Een vervolg onderzoek op deze specifieke studie populatie is niet uitgevoerd. Hierdoor is het niet bekend is hoe lang de verworven ARGs in het darmmicrobioom aanwezig bleven. Hoewel sommige studies de persistentie van verkregen ESBL producerende stammen hebben onderzocht door gebruik te maken van kweek gebaseerde methoden, zou het uitvoeren van metagenomische studies op dit vlak bijdragen aan het inzicht over de dynamiek en lot van verworven ARGs.

In hoofdstuk 4A beschrijven we de observatie dat sommige ARGs in het darmmicrobioom van volwassenen al een hoge prevalentie hadden voorafgaand van de internationale reis en dat deze fluctueerden in hoeveelheid. Deze fluctuaties konden vermoedelijk worden toegeschreven aan de invloeden van het reizen. In hoofdstuk 4B hebben we echter laten zien dat in niet-reizende volwassenen, een zelfde soort fluctuatie voor die specifieke ARGs werd aangetroffen. Waarschijnlijk vertegenwoordigen deze fluctuaties daarom normale, korte termijn veranderingen in de commensale microbiota. Veranderingen in de microbiële samenstelling tijdens internationaal reizen is tot nu toe nog niet onderzocht, maar zou verband kunnen houden met de acquisitie van specifieke ARGs. Het zou bijvoorbeeld zo kunnen zijn dat individuen met een verlaagde kolonisatieresistentie vatbaarder zijn voor veranderingen in microbiële samenstelling, inclusief een verhoging van het aantal Enterobacteriaceae en de daarmee geassocieerde ARGs.

Hoewel wij en anderen hebben laten zien dat de acquisitie van ARGs en antibioticaresistente bacteriën plaats vindt tijdens internationaal reizen, was er geen data beschikbaar over hoe snel ARG acquisitie eigenlijk kan plaatsvinden. Dit spoorde ons aan om ons te concentreren op de dynamiek van het resistoom 
tijdens de reis, zoals beschreven in hoofdstuk 5. Door opeenvolgende monsters te verzamelen voorafgaand, tijdens en na een reis, hebben we kunnen aantonen dat de acquisitie van ARGs al binnen enkele dagen kan plaatsvinden. De mediane tijd tot acquisitie was 5 dagen, hetgeen aangeeft dat dit snel plaatsvindt en dat ook korte bezoeken aan endemische gebieden voldoende zijn om bij te dragen aan de verspreiding van antibioticaresistentie. Ook benadrukt dit de mogelijke implicaties voor korte bezoeken aan andere soorten hoog-risico omgevingen zoals ziekenhuizen of boerderijen. Terwijl acquisitie binnen zeer korte tijd kan plaatsvinden, kunnen de effecten juist langdurig zijn. In onze gelimiteerde populatie grootte waren ARGs in sommige gevallen tot 3 maanden na de reis nog steeds detecteerbaar. Uit andere studies is gebleken dat resistente organismen, welke tijdens het reizen werden verworven, tot 6 maanden tijd persisteerden in 6$24 \%$ van de reizigers. Zo lang het dragerschap van deze resistente bacteriën aanhoudt, is er zowel een verhoogd risico voor infecties met zulke bacteriën, als het risico voor de verdere verspreiding naar bijvoorbeeld andere leden in een huishouden. Bovendien zorgt het voor een constante blootstelling van het milieu door de uitscheiding van resistente bacteriën of ARGs (hoodstuk 2).

Het eerste plasmide gemedieerde colistine resistentie gen ( $m c r-1)$ is pas recent beschreven. De verspreiding van dit gen kan grote gevolgen hebben omdat multidrug resistente bacteriën hierdoor ongevoelig kunnen worden tegen zelfs de laatst beschikbare behandelingsoptie. De informatie over de mate van de verspreiding van dit gen is nog schaars. Hoewel volgens sommige studies het aantal $m c r-1$ positieve stammen die uit dieren of voedsel zijn geïsoleerd vrij hoog was in bepaalde gebieden, zijn rapportages over dragerschap in mensen nog sporadisch. In hoofdstuk 6 onderzochten we of reizigers aan dit gen werden blootgesteld, en daarmee mogelijk een bijdrage leveren aan de verspreiding ervan. In een PCR zijn metagenoom monsters vatbaarder voor het induceren van niet-specifieke amplificatie. Dit komt door de hoge diversiteit in het aanwezige DNA ten opzichte van bijvoorbeeld DNA dat geïsoleerd is uit bacteriële isolaten. Bovendien werd er aangetoond dat de PCR opstelling van Lui et al. vals-positieve uitslagen genereerde op bacteriële isolaten. Om op een betrouwbare manier het (fecale) metagenoom voor de aanwezigheid van mcr-1 te kunnen onderzoeken, hebben we daarom een nieuwe real-time PCR ontworpen. Door gebruik te maken van deze gevoelige en specifieke PCR opstelling ondervonden we dat voor 1 deelnemer het $\mathrm{mcr}-1$ gen in zowel de pre- als post-reis monsters aanwezig was. Daarnaast was bij 5 deelnemers enkel het post-reis monster positief bevonden. 
Dit suggereert dat dit gen al in hoge mate aanwezig is in bepaalde delen van de wereld en bevestigd dat het reizen naar zulk hoog-risico gebieden een risico factor is voor de acquisitie en verspreiding ervan.

Bacteriële isolaten die het $m c r-1$ gen bevatten konden niet van alle fecale monsters worden geïsoleerd. Hoewel dit waarschijnlijk komt door de verminderde levensvatbaarheid van de bacteriën in deze monsters, zou het interessant zijn om de oorsprong van de gedetecteerde genen te achterhalen. Mogelijk zouden deze genen namelijk ook aanwezig kunnen zijn in aanvankelijk niet kweekbare bacteriën. Zodoende zijn er meer studies nodig die de rol van reizen in het verspreiden van $\mathrm{mcr}$-1 uitgebreider bepalen. Door de recente ontdekking van $\mathrm{mcr}$ 1 en de mogelijke implicaties hiervan voor antibiotica therapie, wordt er momenteel op verscheidene plaatsen op de wereld een grote hoeveelheid onderzoek verricht naar het gen. De resultaten van deze en toekomstige onderzoeken zullen leiden tot de benodigde inzichten over de prevalentie en belang van het gen in mensen, dieren en de omgeving. Hieruit kan de ernst van de mcr-1 situatie worden ingeschat en kunnen er gepaste acties worden ondernomen. Een aantal bevindingen wijzen erop dat mcr-1 wellicht een oorsprong heeft in bacteriën die geassocieerd zijn met dieren. Hetgeen vraagt voor zware restricties of zelfs een verbod op het gebruik van polymyxine in de agricultuur.

\section{Concluderende opmerkingen en toekomstperspectieven}

Gezien de opkomst van antibioticaresistentie sinds het gebruik van antibiotica door de mens, is het duidelijk dat er inspanningen moeten worden gemaakt om de verdere verspreiding hiervan te voorkomen. Wanneer we de therapeutische bruikbaarheid wensen te behouden van de huidige en toekomstige antibiotica, moeten er bepaalde maatregelen getroffen worden op een globale schaal. Enkele van de belangrijke aandachtspunten zijn bijvoorbeeld: (I) de immense blootstelling van het milieu aan antibiotica afval; (II) Het grootschalige gebruik van antibiotica als groeibevorderaars en profylactische medicijnen in de agricultuur en (III) het gebruik zonder voorschrift en inadequaat gebruik van antibiotica voor de menselijke geneeskunde.

Maatregelen om deze aandachtspunten beter te reguleren worden door sommige delen van de wereld al genomen. Zo wordt bijvoorbeeld 'antibiotic stewardship' steeds vaker toegepast in zorginstellingen. Ook worden in 
verschillende Noord-Europese landen grote vooruitgangen geboekt in het verminderde gebruik van antibiotica in de agricultuur. De effecten van zulke maatregelen zullen echter voornamelijk gelimiteerd blijven aan specifieke gebieden of landen, omdat in andere delen van de wereld extreme tegenovergestelden gelden. Zo is de ongereguleerde 'over de toonbank' verkoop van antibiotica in sommige landen een alledaagse praktijk, is er een gebrek aan reguleringen voor antibiotica gebruik in de agricultuur en is de ongecontroleerde blootstelling van het milieu aan antibiotica dramatisch.

Ondanks het feit dat een gebrek aan zulke maatregelen misschien slechts regionaal zijn, zal het een wereldwijde toename van antibiotica resistentie blijven voortstuwen middels bijvoorbeeld ruilhandel en reisroutes. Er is daarom nog steeds een behoefte aan het duidelijker definiëren van de invloed van reizen op de verspreiding van antibiotica resistentie. Toekomstige studies moeten tot meer verduidelijking leiden betreffende hoelang dragerschap voortduurt na de acquisitie van ARGs of resistente bacteriën, welk risico dit vormt en of verdere verspreiding plaatsvindt naar bijvoorbeeld andere leden van een huishouden of naar het milieu. Daarnaast is de acquisitie van zowel carbapenemase-coderende genen als dat van mcr-1 ten gevolge van reizen naar endemische landen nog onvoldoende bestudeerd en daarmee een belangrijk aandachtspunt. Carbapenems en polymixines zullen steeds vaker benodigd zijn als behandelingsoptie. Daarom is het van groots belang om de verspreidingsroutes vast te stellen van de genen die coderen voor resistentie tegen deze antibiotica. Het ontrafelen van mens-tot-mens of milieu-gerelateerde verspreidingsroutes kan leiden tot aangrijpingspunten voor het nemen van extra (hygiëne) voorzorgsmaatregelen voor bijvoorbeeld ziekenhuisopnamen van patiënten die recent hebben gereisd naar endemische gebieden. $\mathrm{Er}$ is ook een behoefte aan het in kaart brengen van de gevolgen van de verspreiding van ARGs door menselijke handelen in het algemeen. Zo is er bijvoorbeeld weinig kennis over wat de gevolgen zijn op het resistoom van een omgeving wanneer er een introductie plaatsvindt van ARGs (of de organismen die deze bevatten). Dit heeft betrekking op de initiële acquisitie van ARGs in het darmresistoom van mensen of dieren, maar ook op de daaruit volgende verspreiding naar bijvoorbeeld de directe omgeving, afvalwateren, enzovoorts. Uiteindelijk zal het essentieel zijn om te onderzoeken in welke mate zulke effecten verbonden zijn aan de antibiotica resistentie zoals die voorkomt in de kliniek. 
De huidige tegenslag voor laatste redmiddelen van antibiotica tegen multidrug resistentie, door de ontdekkingen van $\mathrm{mcr}$-1 en $\mathrm{mcr}$-2, heeft benadrukt dat er een dringende nood is aan nieuwe antibiotica. Net zoals de grotendeels onverkende bacteriële ecosystemen talloze ARGs bevatten, zijn deze waarschijnlijk ook een bron van nieuwe antibiotica. Gelijk aan hoe teixobactin recent is ontdekt, kunnen nieuwe manieren om micro-organismen te cultiveren uit ecosystemen zoals grond en water omgevingen, de mogelijkheid bieden om nieuwe antibiotica te ontdekken. Zoals eerder besproken, zullen strikte regulaties voor het gebruik van deze nieuwe antibiotica noodzakelijk zijn. Indien zulke regulaties niet worden nageleefd, is er geen reden dat de therapeutische bruikbaarheid niet hetzelfde lot zal ondergaan als dat van de huidige antibiotica. Zeer waarschijnlijk zal resistentie tegen nieuwe antibiotica voortkomen uit dezelfde ecosystemen als waar deze antibiotica ontdekt zijn. Door het toepassen van metagenomics (metagenoom technieken) zou deze resistentie kunnen worden ontdekt en gemonitord voordat deze opduikt in menselijke pathogenen, als deze daar niet al aanwezig is. Door het uitvoeren van functionele metagenomic studies, zullen nieuwe genen die coderen voor resistentie tegen de huidige antibiotica worden ontdekt. Dit zal de annotatie kracht van sequence gebaseerde studies verbeteren. Hetgeen ervoor zorgt dat er meer informatie kan worden gewonnen uit zowel het sequencen van bacteriële gemeenschappen als uit al bestaande sequence data. Ook zal het identificeren van onbekende ARGs het mogelijk maken om met targeted metagenomic technieken zulke bacteriële gemeenschappen te onderzoeken voor het vóórkomen van deze genen.

Het vóórkomen en de verspreiding van antibiotica resistentie, niet alleen in menselijke pathogenen, maar in alle bacteriële ecosystemen die kunnen dienen als een potentieel reservoir van resistentie, kan verder worden ontrafeld door gebruik te maken van een combinatie van deze verschillende metagenoom technieken. Deze inspanningen zullen nodig zijn om de juiste maatregelen te kunnen nemen tegen het verspreiden van resistentie tegen zowel de huidige, als toekomstige antibiotica. 
Valorisation 


\section{Relevance for society and economy}

The antibiotic resistance encountered in human pathogens is a huge concern for public health worldwide. Because of this resistance, effective treatment options for bacterial infections are often limited and in some cases may no longer be available at all. This reduces clinical efficacy, increases treatment costs and causes a great amount of otherwise preventable mortality. In the Review on Antimicrobial Resistance, commissioned by the UK government, it was stated that "Antimicrobial resistance (AMR) kills around 50,000 people a year in the US and Europe, and is estimated to kill more than 700,000 people globally." [1]. The global production and consumption of antibiotics is enormous, and was shown to have drastically increased over de last few years [2], causing a constantly increasing selection pressure on bacteria in all exposed environments. The use and misuse of antibiotics in medicine, agriculture, and aquaculture has been linked to the emergence of resistant bacteria in these settings [3-5]. As such, the antibiotic resistance problem is rapidly increasing. Moreover, with the lack of development of novel antibiotics, the increasing resistance to the current lastresort antibiotics foreshadows a grim situation where untreatable infections will become increasingly more common.

In order to illustrate how catastrophic the problem is likely to become if the current trend is not changed, the authors of the Review on Antimicrobial Resistance made crude estimates of the future burdens of antimicrobial resistance. They estimated that by the year 2050, 10 million people would die annually because of antimicrobial resistance, overtaking even the number of deaths attributed to cancer [6]. The economic costs will similarly be enormous, as indicated by their estimation that "the world's GDP will be 2 to $3.5 \%$ lower than it otherwise would be in 2050", and that "It would cost the world up to 100 trillion USD" [6].

\section{Target groups}

The antibiotic resistance problem concerns an exceptionally broad audience, as anyone can be at risk for unfortunate infections with resistant pathogens. As such, this work can be of interest to both professionals in health care as well as the general population. In order to achieve appropriate usage of antibiotics, it is essential that general practitioners, as well as all medical doctors in health care 
facilities which prescribe antibiotics understand the mechanisms which drive antibiotic resistance. This work may aid in realizing such an understanding. Since this work addresses the risks of acquiring antibiotic resistant bacteria as a result of international travel, it should also be of interest to general practitioners and infection prevention specialists with regards to assessing risk cases for patients. It is also important to increase the awareness of the general population on the concept of antibiotic resistance, since such an understanding will stimulate the responsible use of antibiotic usage. Additionally, this work can be of interest to policy makers of government ministries of health, as appropriate government regulations are essential in achieving national and global guidelines to tackle the antibiotic resistance problem.

\section{Activities, innovations, planning and realization}

While antibiotic resistance is increasing worldwide, the situation varies extensively between different countries. As such, international collaborations are required to aid countries which struggle with high and inadequate antibiotic usage. Because of the dissemination of antibiotic resistance through trade, travel and migration, these problems are a global concern and should be tackled as such. Extending the knowledge and resources of countries which are doing relatively well in this respect could lead to reduced and better regulated usage of antibiotics worldwide. This is essential since the reduction of resistant bacteria in highly problematic areas will subsequently result in a decreased spread of antibiotic resistance towards other countries.

An important point of focus would be to work towards a global ban of overthe-counter sales of antibiotics, along with conservative and appropriate prescription by healthcare personal. In order to establish this, it will be necessary to create awareness of the consequences of antibiotic use. For healthcare professionals, this could be realized by additional trainings. To ensure that prescribed antibiotics are used responsibly, awareness must also be created among the general population, through e.g. government regulated informative commercials or education. Since other animals or even the environment may serve as reservoirs of resistance, it is also important to promote regulations of antibiotic usage in agriculture. Currently such regulations are non-existent in many countries, which attributes to the high rates of resistance encountered in animals. 
Furthermore, by improving the global surveillance of antibiotic resistance in both pathogens and commensals, possible sources for the dissemination of resistance may be more clearly defined. This work has contributed to identifying such sources of dissemination. Moreover, we have provided novel approaches to perform antibiotic resistance surveillance in whole microbial communities. As we have shown, this allows for the identification of a broader range of risk factors. With information obtained from these efforts, the appropriate precautions can be undertaken to limit further dissemination of antibiotic resistance. This could be reflected in e.g. additional hygiene precautions, controls for imported foods, or screening of hospital admittance of patients returning from high risk areas.

\section{References}

1. Review on AMR, Tackling drug-resistant infections globally: final report and recommendations, 2016. https://amr-review.org

2. Van Boeckel TP, Gandra S, Ashok A, Caudron Q, Grenfell BT, Levin SA, et al. Global antibiotic consumption 2000 to 2010: an analysis of national pharmaceutical sales data. Lancet Infect Dis. 2014;14(8):742-50.

3. Cabello FC. Heavy use of prophylactic antibiotics in aquaculture: a growing problem for human and animal health and for the environment. Environ Microbiol. 2006;8(7):1137-44.

4. Economou V, Gousia P. Agriculture and food animals as a source of antimicrobialresistant bacteria. Infect Drug Resist. 2015;8:49-61.

5. Penders J, Stobberingh EE. Antibiotic resistance of motile aeromonads in indoor catfish and eel farms in the southern part of The Netherlands. Int J Antimicrob Agents. 2008;31(3):261-5.

6. Review on AMR, Antimicrobial Resistance: Tackling a crisis for the health and wealth of nations, 2016. https://amr-review.org 
Dankwoord 


\section{Dankwoord}

$\mathrm{Na}$ al het wetenschappelijke schrijfwerk nu even een moment om terug te blikken op de afgelopen vier jaar. Bij de totstandkoming van dit proefschrift zijn een hoop mensen betrokken geweest, waarvoor ik ze graag wil bedanken.

\section{Mijn promotieteam}

Mijn copromotores Petra en John, bedankt voor het aanbieden van deze kans, voor het vertrouwen, voor de geweldige samenwerking, de constructieve kritiek, het dienen als voorbeeld en bovenal voor een geweldige ervaring. Jullie hebben mij bij elke stap van het proces begeleid en voorzien van wijsheid.

Petra, het begon allemaal toen jij me de mogelijkheid bood voor dit promotietraject, waarvoor ik ontzettend dankbaar ben. We gingen meteen snel van start en hebben altijd een prettige samenwerking gehad. Ook ben ik dankbaar voor de vrijheid die jij me in dit project gegeven hebt. Telkens weer wist je me te motiveren en de goede richting op te sturen.

John, ook onze samenwerking verliep vlekkeloos. Bedankt voor het toevoegen van jouw enorme kennis en kunde in dit project. Tot slot nog iets wat je vast vaker hoort, maar ook ik ga zeggen: ontzettend bedankt voor de hulp bij de statistiek.

De manier waarop jullie twee samenwerken mag ook zeker even een eervolle vermelding krijgen. Of het nu gaat om het aansturen van een project of het nakijken van geschreven teksten, jullie zitten altijd op één lijn. Ondanks jullie ontzettend drukke agenda's hebben jullie mij altijd kunnen ondersteunen. Weet dat ik jullie beide ontzettend waardeer!

Mijn promotor, Paul, bedankt voor de gelegenheid om op deze afdeling onderzoek te kunnen doen en te kunnen promoveren. Ook uw betrokkenheid bij presentaties op congressen en de altijd nuttige feedback op abstracts, artikelen en dit proefschrift waardeer ik enorm.

\section{Mijn (ex-) collega's van de afdeling}

Patrick, het is een tijd geleden sinds wij contact hebben gehad, maar het ontbreken van jouw naam hier is absoluut ondenkbaar. Met jou als leermeester begon mijn eerste stage bij de MMB Maastricht. Mijn handelingen in het lab dragen dan ook tot op de dag van vandaag jouw afdruk. Jij zag het idee om na mijn bachelor opleiding nog verder te leren ook helemaal zitten en regelde zelfs 
een afspraak bij een coördinator van de masteropleiding. Bedankt voor alles, mede dankzij jou heb ik zover kunnen komen.

Ellen, hoewel onze samenwerking grotendeels van vóór mijn promotietijd op de afdeling was, wil ik ook $u$ hier voor alles ontzettend bedanken. Regelmatig komen wij elkaar nog tegen op congressen en bijeenkomsten, waarbij ik me dan telkens een geweldige en leerzame stagetijd bij het MUMC+ herinner. Tot op het volgende congres!

Erik, voor vragen op het lab kon ik bij jou altijd terecht. Inmiddels kennen wij elkaar al zo'n 8 jaar en in die tijd heb ik veel van jou kunnen leren. Bedankt voor alles, zonder jou zou het C-lab zeker niet hetzelfde zijn.

Christel en Mayk, wij kennen elkaar al net zo lang en ook jullie wil ik bedanken voor alle hulp in het lab.

Natuurlijk ook aan alle overige mede auteurs van de artikelen: Astrid, Christian, Danyta, Jakob, Julius, Lieke, Nathan en Rianne, bedankt voor jullie bijdrage en voor de feedback op de publicaties.

Beste mede (ex-) promovendi, waarvan velen ook (ex-) kamergenoten. Over 4 jaar tijd zijn er heel wat mensen gekomen en gegaan. Anne, Amita, Birke, Brian, Carla, Charlotte, Christel, Danyta, Julius, Kevin, Niels en Tanja; bedankt voor jullie hulp, het uitwisselen van gedachten en ideeën, maar ook voor de gezellige koffiepauzes, lunches, borrels, uitstapjes en feesten.

En natuurlijk wil ik alle andere medewerkers van de afdeling bedanken voor de samenwerking, voor het delen van jullie kennis en voor de geweldige tijd.

Abdullah, Fahad, Nader and Snehali, since your Dutch has not yet reached perfection, I will make it easy on you and write this paragraph in English. Thank you all for the times we had together, the interesting stories you shared, and the work we did together.

\section{De paranimfen}

Uiteraard ook een aantal woorden voor mijn paranimfen, Dennis en Tim. Al sinds de middelbare school zijn we goed bevriend en nu, jaren later, zijn we hier beland. Enkele jaren al zijn we nu werkzaam of studerend op steenworp afstand van elkaar bij de UM, MAASTRO clinic of het AZM. Het eerste deel van deze periode reden we dan ook elke dag met zijn drieën samen naar Maastricht en terug. Nadat Dennis naar Maastricht verhuisde, hebben Tim en ik deze traditie voortgezet. Samen even goed wakker worden met een 'bulletje' (Red Bull), lachen 
om van alles en nog wat en klagen over de mede weggebruikers: een periode om nooit te vergeten! Maar ook jullie zijn bezig met een promotietraject en ik verwacht binnenkort dan ook niets dan lovende woorden over mij in jullie dankwoorden!

\section{Familie en vrienden}

Mijn hele familie en al mijn vrienden wil ik bedanken voor de betrokkenheid en interesse voor mijn werkzaamheden in Maastricht. In de weekenden kon ik natuurlijk altijd op jullie rekenen voor de nodige feestjes en ontspanning.

Elleke, de afgelopen periode heb ik de last van bijna alle huishoudelijke taken op jou laten vallen. Ik weet wel dat je dat begrijpt, maar daar gaan we vanaf nu weer een eerlijke verdeling in maken. Bedankt voor alle steun en ook voor het bijschaven van mijn zwaar verengelste grammatica van de Nederlandse samenvatting van dit proefschrift.

Mam, pap, bedankt voor de kansen en vrijheden die jullie ons gegeven hebben. Bedankt voor alle hulp en begeleiding. Dat ik hier ben gekomen heb ik aan jullie te danken. 


\section{Curriculum vitae}




\section{Curriculum vitae}

Christian von Wintersdorff werd geboren te Brunssum op 29 maart 1987. Na het behalen van het VWO diploma aan het Rombouts College in 2006, begon hij aan zijn opleiding Biologie en Medisch Laboratoriumonderzoek aan de Hogeschool Zuyd te Heerlen. Eind 2009 behaalde hij daar zijn bachelor diploma, met de research als afstudeerrichting. Na een korte periode werkzaam te zijn geweest op de afdeling van de Medische Microbiologie in het Maastricht Universitair Medisch Centrum (MUMC+), begon hij in 2010 met de master opleiding Clinical Molecular Sciences aan de Universiteit Maastricht. Twee jaar later sloot hij op dezelfde afdeling Medische Microbiologie zijn afstudeerstage af en behaalde daarmee zijn masterdiploma. Aansluitend begon hij op deze afdeling ook met zijn promotieonderzoek onder begeleiding van prof. dr. Paul Savelkoul, dr. John Penders en dr. ir. Petra Wolffs. Per augustus 2016 is hij werkzaam als onderzoeker binnen dezelfde vakgroep van het MUMC+, waar hij verder onderzoek verricht naar het vóórkomen en de verspreiding van antibioticaresistentie. 


\section{List of publications}




\section{Full articles}

Brink AA, von Wintersdorff CJ, van der Donk CF, Peeters AM, Beisser PS, Stobberingh EE, Wolffs PF. Development and validation of a single-tube multiple-locus variable number tandem repeat analysis for Klebsiella pneumoniae. PLoS One. 2014 Mar 10;9(3):e91209.

von Wintersdorff CJ, Penders J, Stobberingh EE, Oude Lashof AM, Hoebe CJ, Savelkoul PH, Wolffs PF. High rates of antimicrobial drug resistance gene acquisition after international travel, The Netherlands. Emerg Infect Dis. 2014 Apr;20(4):649-57.

Wijnands KA, Meesters DM, van Barneveld KW, Visschers RG, Briedé JJ, Vandendriessche $B$, van Eijk HM, Bessems $B A$, van den Hoven $N$, von Wintersdorff $C J$, Brouckaert $P$, Bouvy ND, Lamers WH, Cauwels A, Poeze M. Citrulline Supplementation Improves Organ Perfusion and Arginine Availability under Conditions with Enhanced Arginase Activity. Nutrients. 2015 Jun 29;7(7):5217-38.

von Wintersdorff CJ, Penders J, van Niekerk JM, Mills ND, Majumder S, van Alphen LB, Savelkoul PH, Wolffs PF. Dissemination of antimicrobial resistance in microbial Ecosystems through horizontal gene transfer. Front Microbiol. 2016 Feb 19;7:173.

von Wintersdorff CJ, Wolffs PF, Savelkoul PH, Nijsen RR, Lau S, Gerhold K, Hamelmann E, Penders J. The gut resistome is highly dynamic during the first months of life. Future Microbiol. 2016 Apr;11:501-10.

von Wintersdorff CJ, Wolffs PF, van Niekerk JM, Beuken E, van Alphen LB, Stobberingh EE, Oude Lashof AM, Hoebe CJ, Savelkoul PH, Penders J. Detection of the plasmidmediated colistin-resistance gene mcr-1 in faecal metagenomes of Dutch travellers. J Antimicrob Chemother. 2016 Aug 23. pii: dkw328. [Epub ahead of print].

von Wintersdorff CJ, Mills ND, Penders J, Tedjo DI, Savelkoul PH, Wolffs PF. Acquisition of travel-associated antibiotic resistant bacteria occurs within several days. In preparation.

Majumder D, von Wintersdorff CJ, Choudhuri P, Penders J, van Alphen LB, Hoebe CJ, Wolffs PF. Targeted metagenomic assessment of the nasal resistome among two populations, India and The Netherlands: a cross-sectional study. In preparation. 
Malin J, von Wintersdorff CJ, Penders J, Savelkoul PH, Wolffs PF. Longitudinal fluctuations of common antimicrobial resistance genes in the gut microbiomes of healthy Dutch individuals. In preparation.

\section{Abstracts}

\section{Oral presentations}

von Wintersdorff CJ, Penders J, Stobberingh EE, Oude Lashof AM, Hoebe CJ, Savelkoul PH, Wolffs PF. Monitoring changes in the resistome of travellers. Oral presentation at: the Scientific Spring Meeting KNVM \& NVMM; 2013; April 16-17; Papendal, the Netherlands.

von Wintersdorff CJ, Penders J, Stobberingh EE, Oude Lashof AM, Hoebe CJ, Savelkoul PH, Wolffs PF. Targeted resistome detection reveals high acquisition rates of ESBL and quinolone resistance genes in the gut microbiota after international travel. Oral presentation at: the Scientific Spring Meeting KNVM \& NVMM; 2014; April 15-16; Papendal, the Netherlands.

von Wintersdorff CJ, Wolffs PF, Savelkoul PH, Nijsen RR, Lau S, Gerhold K, Hamelmann E, Penders J. Gut resistome development in neonates monitored in a cohort study. Oral presentation at: 6th Congress of European Microbiologists; 2015; Jun 7-11; Maastricht, the Netherlands.

von Wintersdorff CJ, Mills ND, Penders J, Tedjo DI, Savelkoul PH, Wolffs PF. Acquisition of travel-associated antibiotic resistant bacteria occurs within several days. Oral presentation at: 26th European Congress of Clinical Microbiology and Infectious Diseases; 2016; Apr 9-12; Amsterdam, the Netherlands.

von Wintersdorff CJ, Penders J, Savelkoul PH, Stobberingh EE, Wolffs PF. Monitoring changes in the resistome of travelers. Poster session presented at: 23rd European Congress of Clinical Microbiology and Infectious Diseases; 2013 Apr 27-30; Berlin, Germany. 


\section{Poster presentations}

von Wintersdorff CJ, Penders J, Stobberingh EE, Oude Lashof AM, Savelkoul PH, Wolffs PF. Metagenomic molecular determination of antibiotic resistance: unravelling changes in the resistome of travelers. Poster session presented at: 8th European Meeting on Molecular Diagnostics; 2013 Oct 2-4; Scheveningen, the Netherlands.

Von Wintersdorff CJ, Penders J, Savelkoul PH, et al. Early development of the human gut resistome explored in a birth cohort study. Poster session presented at: 24th European Congress of Clinical Microbiology and Infectious Diseases; 2014; May 1013; Barcelona, Spain.

von Wintersdorff CJ, Penders J, Savelkoul PH, Nijsen RR, Hamelmann E, Lau S, Gerhold K, Wolffs PF. Pediatric gut resistome development explored in a cohort study. Poster session presented at: The Scientific Spring Meeting KNVM \& NVMM; 2015 Apr 14-15; Papendal, the Netherlands.

von Wintersdorff CJ, Wolffs PF, van Niekerk JM, Beuken E, Stobberingh EE, Oude Lashof AM, Hoebe CJ, Savelkoul PH, Penders J. High Prevalence of Plasmid-mediated Colistin-resistance Gene mcr-1 in Fecal Metagenomes of Dutch travelers. Poster session presented at: the ASM Microbe; 2016; Jun 16-20, Boston, MA.

von Wintersdorff CJ, Wolffs PF, van Niekerk JM, Beuken E, Stobberingh EE, Oude Lashof AM, Hoebe CJ, Savelkoul PH, Penders J. High prevalence of plasmid-mediated colistin-resistance gene mcr-1 in faecal metagenomes of Dutch travellers. Poster session presented at: The Scientific Spring Meeting KNVM \& NVMM; 2016 Mar 2223; Papendal, the Netherlands. 
